Prepared in cooperation with the Tennessee Department of Environment and Conservation, Division of Water Supply

\title{
Public Water-Supply Systems and Associated Water Use in Tennessee, 2005
}

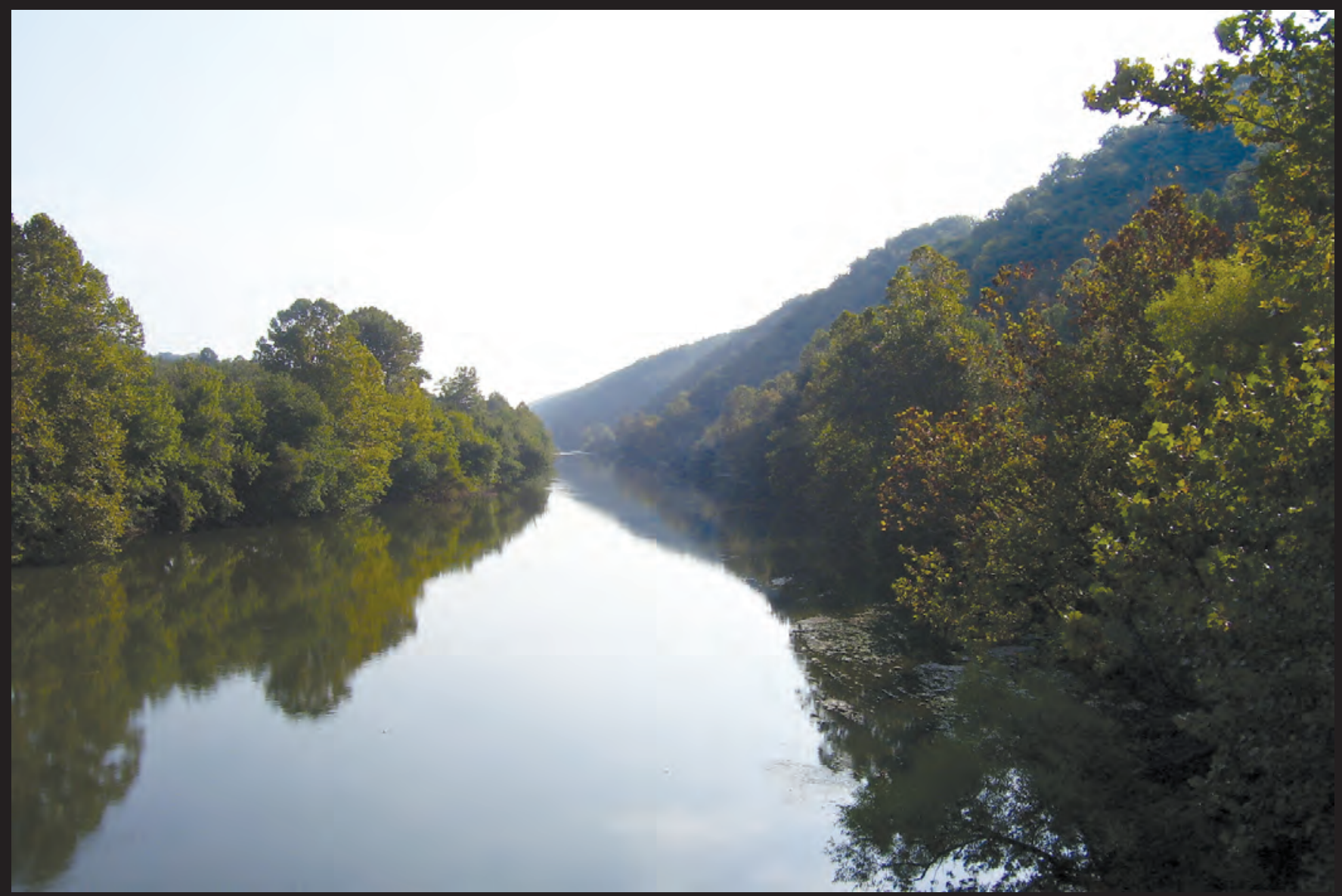

Open-File Report 2010-1226 
Cover photograph. Clinch River at Looney's Gap, Hancock County, Tennessee, northeast of Knoxville. Photo by Melissa Harris, U.S. Geological Survey. 


\section{Public Water-Supply Systems and Associated Water Use in Tennessee, 2005}

By John A. Robinson and Jaala M. Brooks

Prepared in cooperation with the Tennessee Department of Environment and Conservation, Division of Water Supply

Open-File Report 2010-1226 


\title{
U.S. Department of the Interior \\ KEN SALAZAR, Secretary \\ U.S. Geological Survey \\ Marcia K. McNutt, Director
}

\section{U.S. Geological Survey, Reston, Virginia: 2010}

\author{
For more information on the USGS — the Federal source for science about the Earth, its natural and living resources, \\ natural hazards, and the environment, visit http://www.usgs.gov or call 1-888-ASK-USGS \\ For an overview of USGS information products, including maps, imagery, and publications, \\ visit http://www.usgs.gov/pubprod \\ To order this and other USGS information products, visit http://store.usgs.gov
}

\begin{abstract}
Any use of trade, product, or firm names is for descriptive purposes only and does not imply endorsement by the U.S. Government.

Although this report is in the public domain, permission must be secured from the individual copyright owners to reproduce any copyrighted materials contained within this report.
\end{abstract}

Suggested citation:

Robinson, J.A., and Brooks, J.M., 2010, Public water-supply systems and associated water use in Tennessee, 2005: U.S. Geological Survey Open-File Report 2010-1226, 100 p.

ISBN 978-1-4113-2984-3 


\section{Contents}

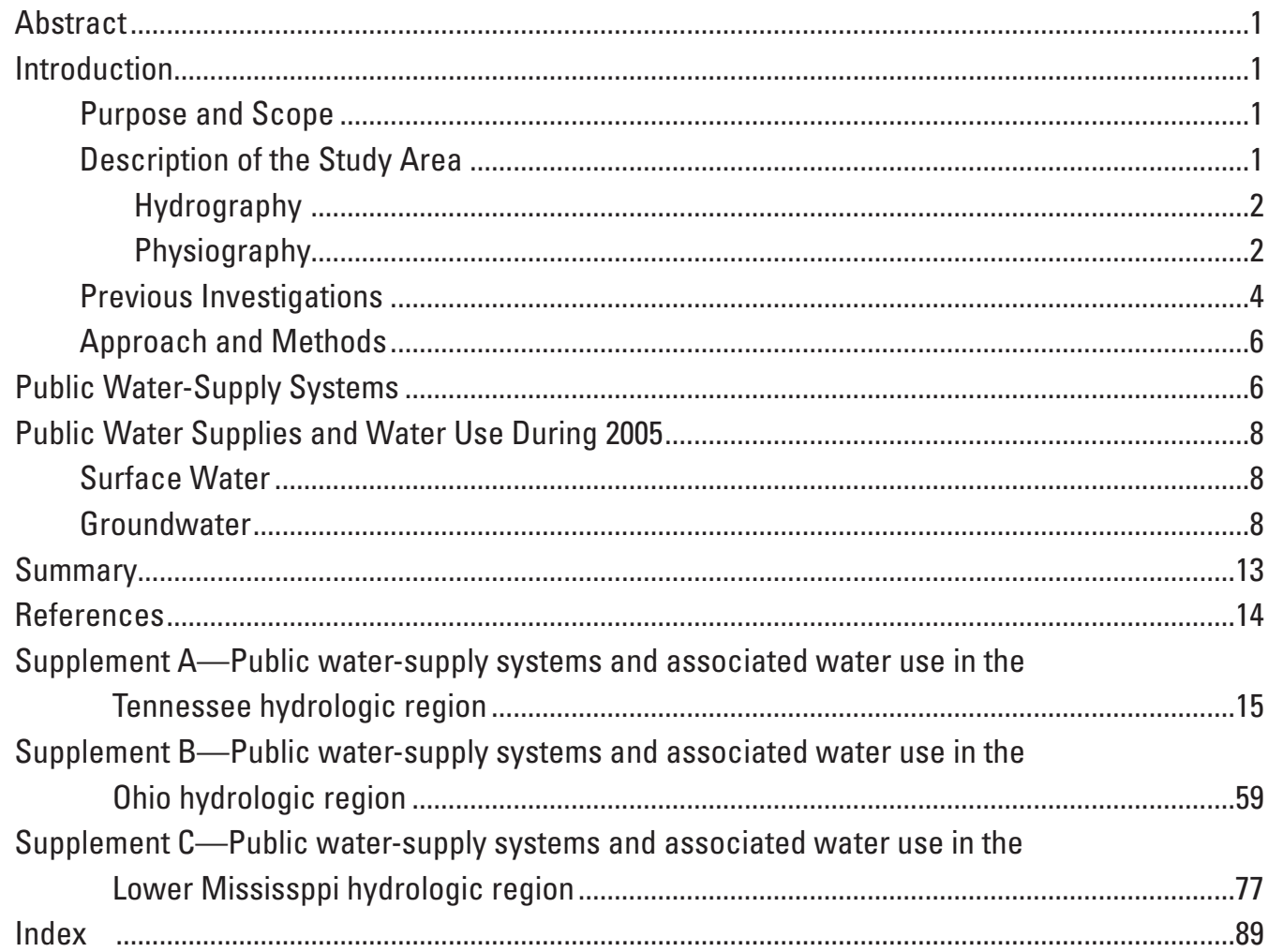

\section{Figures}

1. Map showing major hydrologic regions and subregions and major river

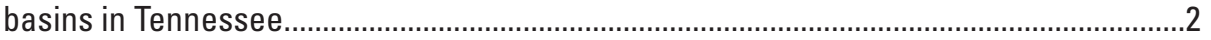

2. Map showing $(A)$ Major physiographic divisions, $(B)$ principal aquifers, and $(C)$ generalized geologic section in Tennessee.............................................................

3. Graph showing surface-water and groundwater withdrawals by public water-supply systems in Tennessee, 1950 to 2005 ......................................................6

4. Map showing distribution of public-supply systems using surface water

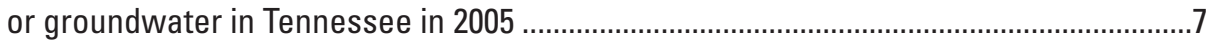

5. Graph showing source of water for public water-supply systems in

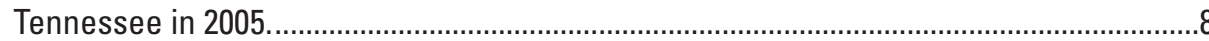

6. Map showing surface-water withdrawal rates for Tennessee counties

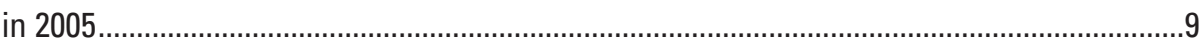

7. Map showing groundwater withdrawal rates for Tennessee counties in 2005

8. Graph showing groundwater withdrawals, in million gallons per day, from principal aquifers in Tennessee in 2005.

9. Map showing principal aquifers in Tennessee and rate of water withdrawal, in million gallons per day, 2005 . 


\section{Tables}

1. Surface-water characteristics of hydrologic subregions and major river basins in Tennessee. 3

2. Aquifer and well characteristics in Tennessee. .5

3. Surface-water withdrawals from Tennessee river basins in 2005

4. Groundwater withdrawals by public water-supply systems in Tennessee using 1 million gallons per day or more

\section{Conversion Factors}

\begin{tabular}{lcl}
\hline \multicolumn{1}{c}{ Multiply } & By & To obtain \\
\hline inch (in.) & \multicolumn{1}{c}{ Length } & \\
\hline & Area & centimeter $(\mathrm{cm})$ \\
\hline square mile $\left(\mathrm{mi}^{2}\right)$ & 2.590 & square kilometer $\left(\mathrm{km}^{2}\right)$ \\
\hline & \multicolumn{1}{c}{ Volume } & \\
\hline gallon (gal) & 3.785 & liter $(\mathrm{L})$ \\
gallon (gal) & 0.003785 & cubic meter $\left(\mathrm{m}^{3}\right)$ \\
acre-foot (acre-ft) & 1,233 & cubic meter $\left(\mathrm{m}^{3}\right)$ \\
\hline & Flow rate & \\
\hline gallon per minute $(\mathrm{gal} / \mathrm{min})$ & 0.06309 & liter per second $(\mathrm{L} / \mathrm{s})$ \\
gallon per day (gal $/ \mathrm{d})$ & 0.003785 & cubic meter per day $\left(\mathrm{m}^{3} / \mathrm{d}\right)$ \\
million gallons per day $(\mathrm{Mgal} / \mathrm{d})$ & 0.04381 & cubic meter per second $\left(\mathrm{m}^{3} / \mathrm{s}\right)$ \\
\hline
\end{tabular}

Temperature in degrees Fahrenheit $\left({ }^{\circ} \mathrm{F}\right)$ may be converted to degrees Celsius $\left({ }^{\circ} \mathrm{C}\right)$ as follows:

$$
{ }^{\circ} \mathrm{C}=\left({ }^{\circ} \mathrm{F}-32\right) / 1.8
$$

Vertical coordinate information is referenced to the National Geodetic Vertical Datum of 1929 (NGVD 29).

Horizontal coordinate information is referenced to the North American Datum of 1983 (NAD 83). 


\title{
Public Water-Supply Systems and Associated Water Use in Tennessee, 2005
}

\author{
By John A. Robinson and Jaala M. Brooks
}

\section{Abstract}

Public water-supply systems in Tennessee provide water to for domestic, industrial, and commercial uses, and municipal services. In 2005, more than 569 public watersupply systems distributed about 920 million gallons per day (Mgal/d) of non-purchased surface water and groundwater to a population of nearly 6 million in Tennessee. Surface-water sources provided 64 percent (about $591 \mathrm{Mgal} / \mathrm{d}$ ) of the State's water supplies. Groundwater produced from wells and springs in Middle and East Tennessee and from wells in West Tennessee provided 36 percent (about $329 \mathrm{Mgal} / \mathrm{d}$ ) of the public water supplies. Gross per capita water use for Tennessee in 2005 was about 171 gallons per day.

Water withdrawals by public water-supply systems in Tennessee have increased from $250 \mathrm{Mgal} / \mathrm{d}$ in 1955 to $920 \mathrm{Mgal} / \mathrm{d}$ in 2005. Tennessee public water-supply systems withdraw less groundwater than surface water, and surfacewater use has increased at a faster rate than groundwater use. However, 34 systems reported increased groundwater withdrawals during 2000-2005, and 15 of these 34 systems reported increases of $1 \mathrm{Mgal} / \mathrm{d}$ or more. The county with the largest surface-water withdrawal rate $(130 \mathrm{Mgal} / \mathrm{d})$ was Davidson County.

Each of Tennessee's 95 counties was served by at least one public water-supply system in 2005 . The largest groundwater withdrawal rate (about $167 \mathrm{Mgal} / \mathrm{d}$ ) by a single public water-supply system was reported by Memphis Light, Gas and Water, which served 654,267 people in Shelby County in 2005.

\section{Introduction}

The population of Tennessee in 2005 was estimated as $5,955,745$ by the U.S. Census Bureau (2006). As Tennessee's population has increased with time, so too has the number of people relying on public water-supply systems for their water. Public supply refers to water withdrawn by public or private suppliers that furnish water year round to at least 25 people or have at least 15 service connections (U.S. Geological Survey, 1978). The withdrawal rates reported by the public water-supply systems reflect the demand for water across Tennessee. Studies documenting the number of public water-supply systems and their withdrawal rates provide local and regional government agencies with a better understanding of past and current water use, and provide a basis for accurate estimation of future water needs.

\section{Purpose and Scope}

The U.S. Geological Survey (USGS), in cooperation with the Tennessee Department of Environment and Conservation, Division of Water Supply (TDEC-DWS), prepared this report to provide information on water use by public water-supply systems in Tennessee. The report presents the quantities of water withdrawn and delivered by public water-supply systems in Tennessee for 2005 and lists the sources of water used by the public water-supply systems.

Water-use data for calendar year 2005 were obtained from TDEC-DWS, which regulates public water-supply system withdrawals and usage within Tennessee. Water-use data prior to 2000 were obtained from published reports. The data analyses for this report include graphic summaries and descriptions of water use in Tennessee from 1950 to 2005.

\section{Description of the Study Area}

Tennessee is located in the central southeastern United States, bounded by the Mississippi River on the west and extending to the Blue Ridge Physiographic Province and Appalachian Mountains on the east. Tennessee encompasses 42,126 square miles $\left(\mathrm{mi}^{2}\right)$, which includes $926 \mathrm{mi}^{2}$ of inland water (Webbers, 2003). Land-surface elevations range from about 180 feet above NGVD 29 along the Mississippi River to more than 6,600 feet above NGVD 29 in the mountains of East Tennessee. Rainfall in Tennessee is approximately 50 to 54 inches per year. The three divisions of Tennessee-West, Middle, and East - are characterized by distinct differences in geology, physiography, and hydrography. In West Tennessee, thick unconsolidated sedimentary aquifers provide water for public water supplies. In Middle and East Tennessee, public water supplies come primarily from surface water and, in places, from groundwater sources, such as production wells and springs. 


\section{Hydrography}

Three major hydrologic regions divide the State's surface-water hydrography from West Tennessee to East Tennessee - the Lower Mississippi, the Ohio, and the Tennessee hydrologic regions (fig. 1). A small part of southeastern Tennessee is in the South Atlantic-Gulf region. Within the major hydrologic regions are smaller hydrologic subregions, containing river basins and tributaries (table 1).

In Middle and East Tennessee, the Ohio hydrologic region includes the Cumberland River and its tributaries. The major tributaries of the Cumberland River are the Obey, Caney, Harpeth, Stones, and Red Rivers. The Tennessee hydrologic region includes the Tennessee River and its major tributaries, including the Buffalo, Beech, Big Sandy, Elk, Shoal, Flint, Clinch, French Broad, Holston, Nolichucky, Powell, Little Tennessee, and Tellico Rivers. The Cumberland and Tennessee River basins include an extensive network of reservoirs that store about 8.12 million acre-feet $(2,647$ billion gallons) of water (Hutson, 1990). In West Tennessee, the Lower Mississippi-Hatchie hydrologic region encompasses a draingage area of about $8,907 \mathrm{mi}^{2}$ of water. Surface-water characteristics of the hydrologic subregions and major river basins in Tennessee are described in table 1.

Groundwater for public supply in Tennessee is supplied by eight of the nine principal aquifers (fig. 2, table 2), in the State. The principal aquifers in Tennessee that are used for public water supply are the Alluvial, Tertiary sand, Cretaceous sand, Pennsylvanian sandstone, Mississippian carbonate, Ordovician carbonate, Cambrian-Ordovician carbonate, and the crystalline-rock aquifers (Bradley and Hollyday, 1985). About 73 percent of the groundwater used for public supplies in Tennessee is produced from the Tertiary sand aquifers, primarily the Memphis aquifer, in West Tennessee. In Middle and East Tennessee, groundwater may discharge at large springs, which also are used for water supplies. Information about the aquifers and production well characteristics in Tennessee is given in table 2. Detailed descriptions and water-quality information for the aquifers in Tennessee can be found in the following reports: Brahana and Bradley (1985); Brahana, Bradley, and Mulderink (1986); Brahana, Macy, and others (1986); Brahana, Mulderink, and others (1986); Parks and Carmichael (1989); Kingsbury and Parks (1993); and Gonthier (2000).

\section{Physiography}

The diverse topography of Tennessee includes eight physiographic divisions (fig. 2) that range from broad flood plains in the Coastal Plain Physiographic Province of West Tennessee, to rolling hills and karst plains in the Highland Rim and Central Basin of Middle Tennessee, to steep mountains and deep narrow valleys in the Valley and Ridge and Blue Ridge Physiographic Provinces of East Tennessee. The

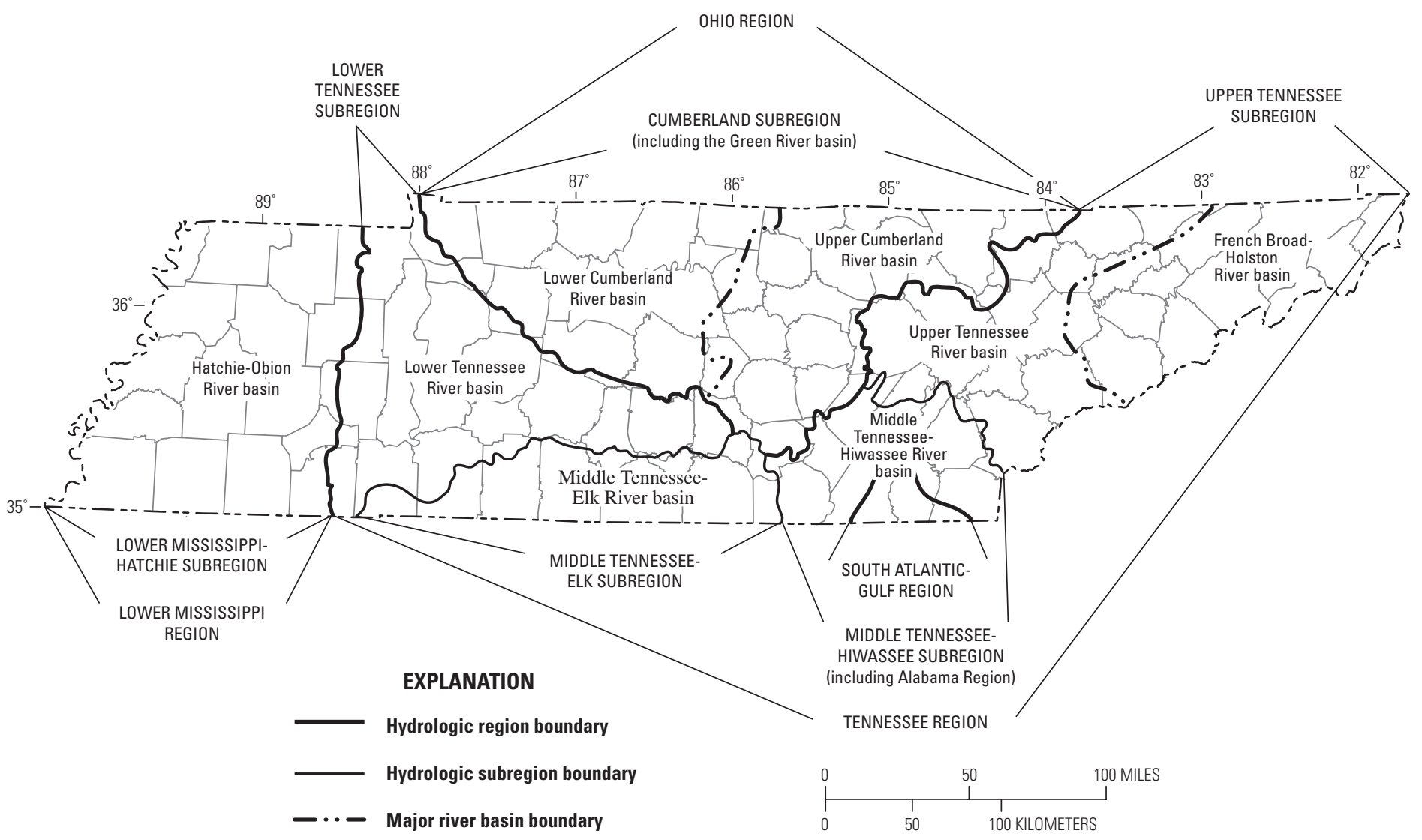

Figure 1. Major hydrologic regions and subregions and major river basins in Tennessee. 


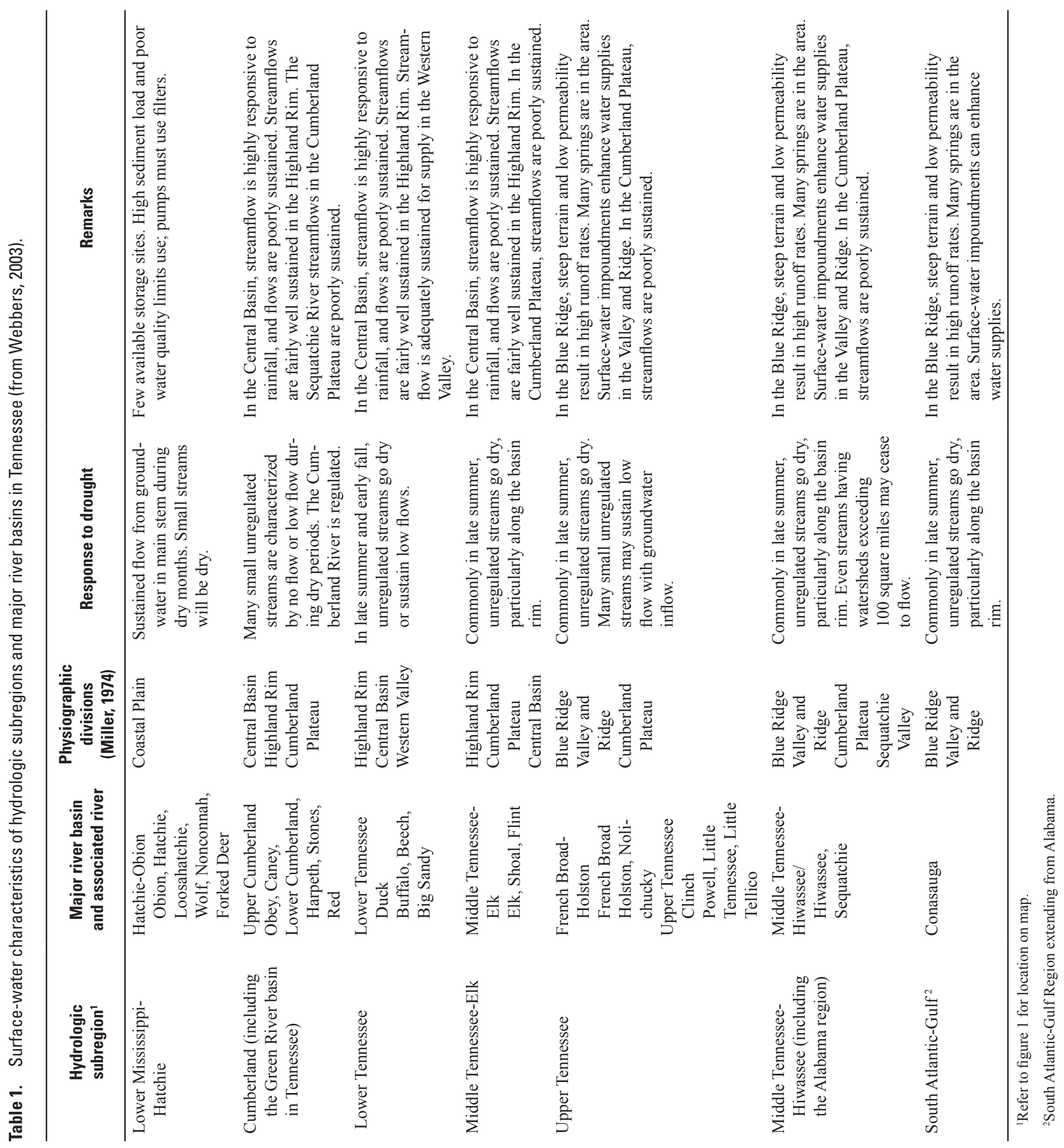


$\boldsymbol{A}$
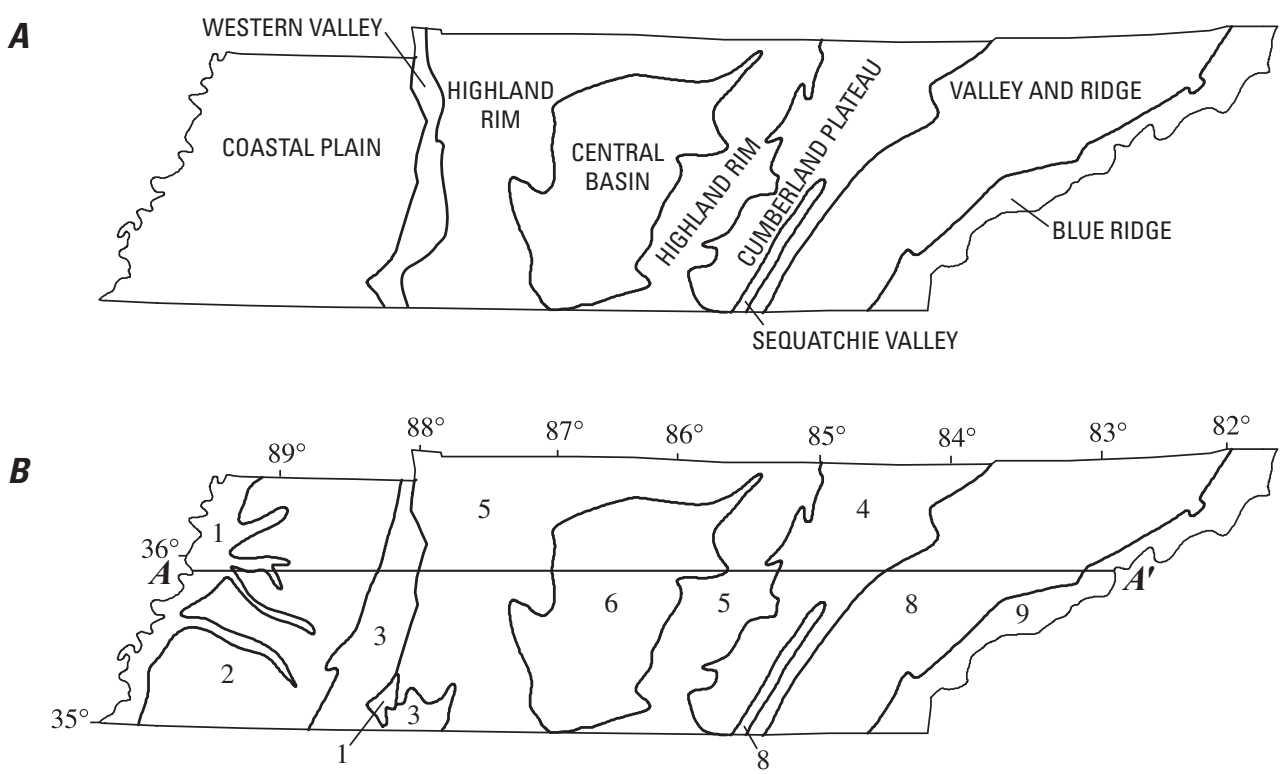

C

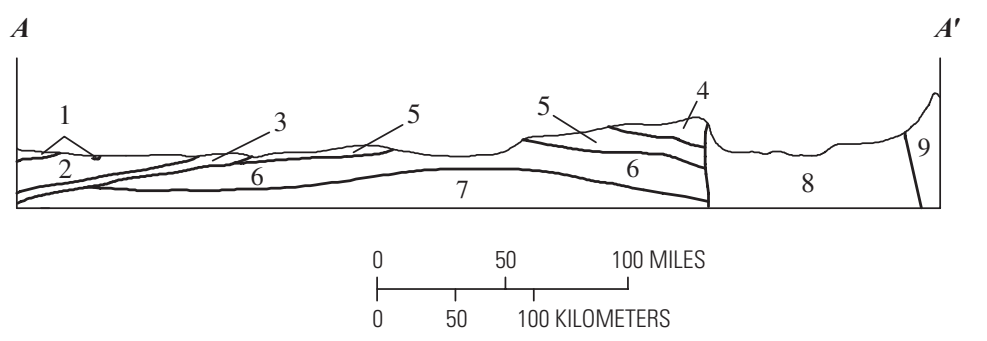

EXPLANATION

Principal aquifers
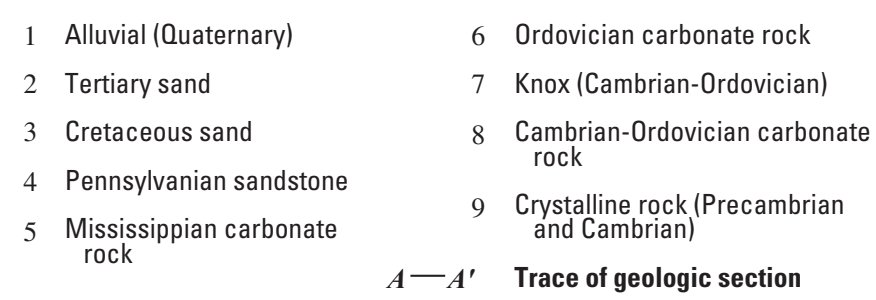

Figure 2. (A) Major physiographic divisions (modified from Fenneman, 1946, and Miller, 1974), $(B)$ principal aquifers (modified from Hollyday and Bradley, 1985), and $(C)$ generalized geologic section in Tennessee (Hollyday and Bradley, 1985).

geology of Tennessee includes unconsolidated sediments of the Coastal Plain in West Tennessee; limestone and dolomite of the Highland Rim and Central Basin in Middle Tennessee; and limestone, sandstone, and shale of the Cumberland Plateau, limestone, dolomite, and shale in the Valley and Ridge Province, and metamorphic and igneous crystalline rocks of the Blue Ridge Physiographic Province in East Tennessee (Miller, 1974).

\section{Previous Investigations}

Previous investigations have published water-use data for Tennessee as part of a national compilation since the 1950s (MacKichan, 1951, 1957) and specific to Tennessee since the 1980s (Alexander and others, 1984; Hutson, 1989). A review of previous investigations describing water use by public water-supply systems in Tennessee from 1950 to 2000 indicates that (1) water withdrawals by public water-supply 
Table 2. Aquifer and well characteristics in Tennessee (modified from Hollyday and Bradley, 1985).

\begin{tabular}{|c|c|c|c|c|c|}
\hline \multirow{3}{*}{ Aquifer name ${ }^{1}$ and description } & \multicolumn{4}{|c|}{ Well characteristics } & \multirow{3}{*}{ Remarks } \\
\hline & \multicolumn{2}{|c|}{ Depth (feet) } & \multicolumn{2}{|c|}{$\begin{array}{c}\text { Yield (gallons per } \\
\text { minute) }\end{array}$} & \\
\hline & $\begin{array}{l}\text { Common } \\
\text { range }\end{array}$ & $\begin{array}{c}\text { May } \\
\text { exceed }\end{array}$ & $\begin{array}{l}\text { Common } \\
\text { range }\end{array}$ & $\begin{array}{c}\text { May } \\
\text { exceed }\end{array}$ & \\
\hline Alluvial: Sand, gravel, and clay. Unconfined. & $10-75$ & 100 & $20-50$ & 1,500 & High iron concentrations in some areas. \\
\hline $\begin{array}{l}\text { Tertiary sand: Multiaquifer unit of sand, clay, } \\
\text { silt, and some gravel and lignite. Confined; } \\
\text { unconfined in the outcrop area. }\end{array}$ & $100-1,300$ & 1,500 & $200-1,000$ & 2,000 & $\begin{array}{l}\text { Includes Memphis Sand of Claiborne Group and } \\
\text { Fort Pillow Sand of Wilcox Group. Problems } \\
\text { with high iron concentrations in some places. }\end{array}$ \\
\hline $\begin{array}{l}\text { Cretaceous sand: Multiaquifer unit of } \\
\text { interbedded sand, clay, marl, and gravel. } \\
\text { Confined; unconfined in the outcrop area. }\end{array}$ & $100-1,500$ & 2,500 & $50-500$ & 1,000 & $\begin{array}{l}\text { Includes McNairy and Coffee Sands, and Tusca- } \\
\text { loosa Formation. Water withdrawn primarily in } \\
\text { the outcrop area. }\end{array}$ \\
\hline $\begin{array}{l}\text { Pennsylvanian sandstone: Multiaquifer unit, } \\
\text { primarily sandstone and conglomerate, in- } \\
\text { terbedded shale and some coal. Unconfined } \\
\text { near land surface; confined at depth. }\end{array}$ & $100-200$ & 250 & $5-50$ & 200 & $\begin{array}{l}\text { Permeability is from fractures, faults, and bed- } \\
\text { ding-plane openings. Principal water-bearing } \\
\text { units are Rockcastle and Sewanee Conglomer- } \\
\text { ates. High iron concentrations are a problem. }\end{array}$ \\
\hline $\begin{array}{l}\text { Mississippian carbonate: Multiaquifer unit } \\
\text { of limestone, dolomite, and some shale. } \\
\text { Unconfined or partly confined near land } \\
\text { surface; may be confined at depth. }\end{array}$ & $50-200$ & 250 & $5-50$ & 400 & $\begin{array}{l}\text { Water occurs in solution and bedding-plane } \\
\text { openings. Principal water-bearing units are Ste. } \\
\text { Genevieve (Monteagle), St. Louis and Warsaw } \\
\text { Limestones and Fort Payne Formation. Water } \\
\text { generally hard; high iron, sulfide, or sulfate } \\
\text { concentrations are a problem in some areas. }\end{array}$ \\
\hline $\begin{array}{l}\text { Ordovician carbonate rock: Multiaquifer unit } \\
\text { of limestone, dolomite, and shale. Partly } \\
\text { confined to unconfined near land surface; } \\
\text { confined at depth. }\end{array}$ & $50-150$ & 200 & $5-20$ & 300 & $\begin{array}{l}\text { Principal water-bearing units are Bigby, Carters, } \\
\text { Ridley, and Murfreesboro Limestones. Water } \\
\text { generally hard; some high sulfide or sulfate } \\
\text { concentrations in places. }\end{array}$ \\
\hline $\begin{array}{l}\text { Knox: Primarily dolomite, some limestone; } \\
\text { confined. Does not have the structural } \\
\text { complexity of the Cambrian-Ordovician } \\
\text { carbonate aquifer. }\end{array}$ & $700-1,200$ & 1,400 & $1-10$ & 20 & $\begin{array}{l}\text { Deep aquifer; present beneath most of central and } \\
\text { western Tennessee. Away from Central Basin, } \\
\text { water generally has high concentrations of dis- } \\
\text { solved solids. }\end{array}$ \\
\hline $\begin{array}{l}\text { Cambrian-Ordovician carbonate: Highly } \\
\text { faulted multiaquifer unit of limestone, } \\
\text { dolomite, sandstone, and shale; structurally } \\
\text { complex. Unconfined; confined at depth. }\end{array}$ & $100-300$ & 400 & $5-200$ & 2,000 & $\begin{array}{l}\text { Principal water-bearing units are carbonate rocks } \\
\text { in Chickamauga Limestone, Knox Group, and } \\
\text { Honaker Dolomite. Water is generally hard. } \\
\text { Brine below 3,000 feet. }\end{array}$ \\
\hline $\begin{array}{l}\text { Crystalline rock: Multiaquifer unit of dolo- } \\
\text { mite, granite gneiss, phyllite, and metasedi- } \\
\text { mentary rocks overlain by thick regolith; } \\
\text { alluvium and colluvium in some valleys. } \\
\text { Generally unconfined. }\end{array}$ & $50-150$ & 200 & $5-50$ & 1,000 & $\begin{array}{l}\text { High yields occur primarily in dolomite or deep } \\
\text { colluvium and alluvium. Shady Dolomite is a } \\
\text { principal aquifer. Low pH and high iron con- } \\
\text { centrations may be problems in some areas. }\end{array}$ \\
\hline
\end{tabular}

${ }^{1}$ Refer to figure 2 for location map.

systems in Tennessee have increased, (2) surface water provided most (54 percent) of Tennessee's public water supplies, and (3) surface-water use has increased at a faster rate than groundwater use (MacKichan, 1951, 1957; Murray and Reeves, 1972, 1977; Hutson, 1989, 1991, 1999; Hutson and Morris, 1992; Solley and others, 1993; Webbers, 2003).

The combined municipal withdrawals of groundwater and surface water were estimated at $160 \mathrm{Mgal} / \mathrm{d}$ in 1950 , with groundwater withdrawals estimated to be $85 \mathrm{Mgal} / \mathrm{d}$ and surface-water withdrawals estimated to be $75 \mathrm{Mgal} / \mathrm{d}$ (MacKichan, 1951, 1957; Murry and Reeves, 1972, 1977; Hutson, 1989, 1991, 1999; Hutson and Morris, 1992; Solley and Others, 1993; Webbers, 2005) (fig. 3). In 1955, total public water withdrawals for Tennessee were estimated at 250 Mgal/d (MacKichan, 1957). By 1970, total public water withdrawals had reached approximately $400 \mathrm{Mgal} / \mathrm{d}$ (Murray and Reeves, 1977). From 1988 to 1990, surface-water withdrawals decreased slightly from 446 to $426 \mathrm{Mgal} / \mathrm{d}$. Ground-water withdrawals in the State, however, increased slightly during the same time, from $262 \mathrm{Mgal} / \mathrm{d}$ (Hutson and Morris, 1992) to $269 \mathrm{Mgal} / \mathrm{d}$ (Solley and others, 1993). In 1995, total withdrawals by public water-supply systems reached $779 \mathrm{Mgal} / \mathrm{d}$ (Hutson, 1999), a 53-percent increase since 1980 (510 Mgal/d). Overall growth in public water supplies during 1988 reflected 


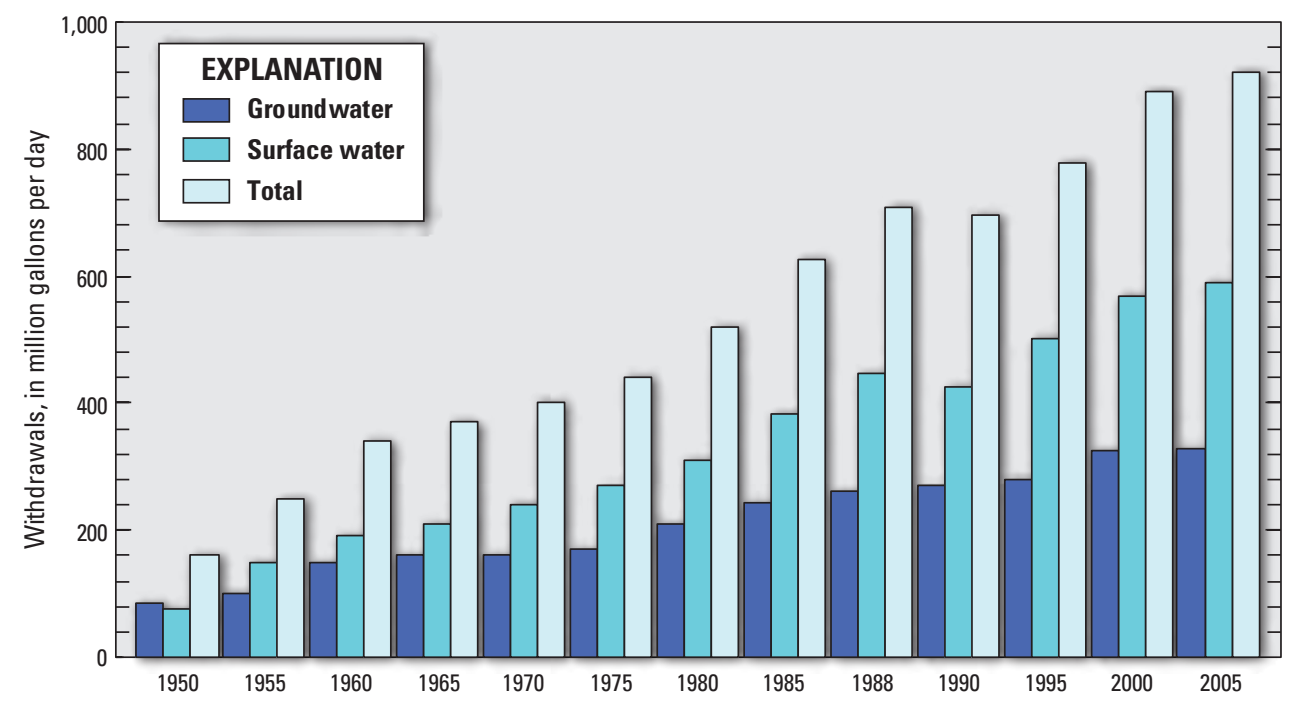

Figure 3. Surface-water and groundwater withdrawals by public water-supply systems in Tennessee, 1950 to 2005. (MacKichan, 1951, 1957; Murray and Reeves, 1972, 1977; Hutson, 1989, 1991, 1999; Hutson and Morris, 1992; Solley and others, 1993; Webbers, 2003)

changing demands and patterns of water use in the commercial and industrial sectors (Hutson and Morris, 1992). However, the number of water systems distributing public water supplies in Tennessee decreased from 541 in 1988 (Hutson and Morris, 1992) to 530 systems in 1995 (Hutson, 1999).

\section{Approach and Methods}

To assess water use in Tennessee, data were collected and analyzed for public water-supply systems active between January 1 and December 31, 2005. The public water-supply systems included investor-owned water companies, private water companies, municipal water departments, regional water authorities, residential developments, mobile home parks, homeowner associations, and institutions such as schools and prisons. Each water system supplied TDEC, DWS, with monthly operating reports that included information on the source of water, mean daily or monthly water withdrawal rates, and the population served. In some instances, public water-supply systems were contacted to supplement missing data or verify reported data.

Monthly and annual average water withdrawals of each public water-supply system were separated into categories of surface water, groundwater, and purchased water. The withdrawal rates of systems using surface-water and groundwater supplies were calculated and compared with historic withdrawal rates and with changes in the population served. The amounts of water purchased by public water-supply systems are not included in the calculations for the amount of water withdrawn from the surface-water basins or from the aquifers. The amount of purchased water used by a system is included in the gross per capita water use by the population served listed in the supplemental tables (Supplements A, B, and C) near the end of this report.

\section{Public Water-Supply Systems}

Public water-supply systems may use a river or stream as a surface-water source, withdraw water from a drilled well or spring as a groundwater source, or purchase water from another water system. In 2005, Tennessee was served by 569 public water-supply systems with 379 systems providing $920 \mathrm{Mgal} / \mathrm{d}$ of non-purchased groundwater or surface-water supplies to about 90 percent of the population. The remaining 190 systems relied entirely on water purchased from other water systems to provide about $87.8 \mathrm{Mgal} / \mathrm{d}$ of purchased water supplies to Tennessee residents.

Of the 379 public water-supply systems withdrawing water, 144 systems withdrew surface water and 235 systems withdrew groundwater. Sixteen of these 379 systems used both surface and groundwater. Supplements A, B, and C provide information about the water source(s) for each public water-supply system; the amount of water withdrawn, sold, or purchased; the population served by each system; and the gross per capita water use for each system when such information is known. An index of the public water-supply systems in Tennessee which are included in the report is provided and sorted by system name and includes the public water-supply system identification number and identifies the supplement table where data for the system are located.

Each of Tennessee's 95 counties was served by at least one public water-supply system in 2005 (fig. 4). The largest groundwater withdrawal rate (about $167 \mathrm{Mgal} / \mathrm{d}$ ) by a single public water-supply system was reported by Memphis Light, 


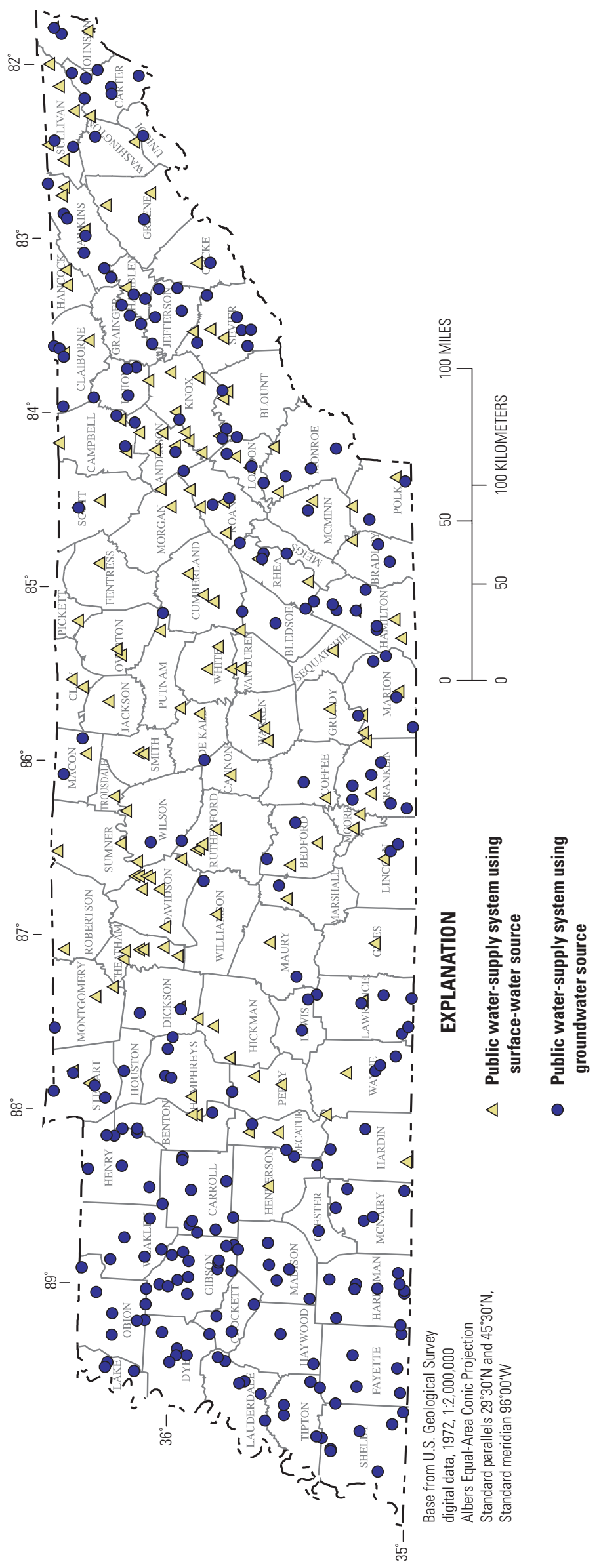

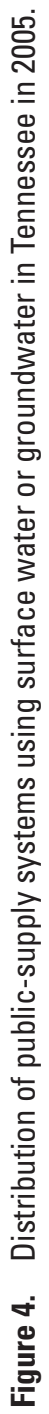


Gas and Water (MLGW), which served 654,267 people in Shelby County in 2005 (Supplement C). The county with the largest surface-water withdrawal rate $(130 \mathrm{Mgal} / \mathrm{d})$ was Davidson County (Supplement A).

\section{Public Water Supplies and Water Use During 2005}

During 2005, Tennessee's public water-supply systems withdrew about $920 \mathrm{Mgal} / \mathrm{d}$, which is a combined withdrawal of 64 percent surface water $(591 \mathrm{Mgal} / \mathrm{d})$ and 36 percent groundwater (329 Mgal/d) (fig. 5). A discussion of surfacewater and groundwater withdrawals during 2005 and how they compare to previous years' withdrawals follows.

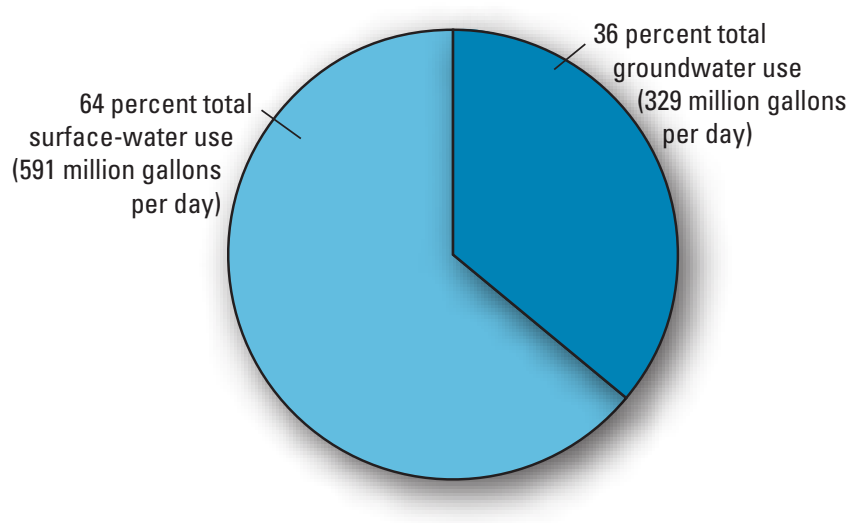

Figure 5. Source of water for public water-supply systems in Tennessee in 2005.

\section{Surface Water}

In 2005, surface water provided approximately $591 \mathrm{Mgal} / \mathrm{d}$ of the total non-purchased public water supplies distributed by water systems in Tennessee. This quantity represents an increase of about $22 \mathrm{Mgal} / \mathrm{d}$ (about 4 percent) since 2000 (569 Mgal/d) (fig. 4). The ratio of surface-water to groundwater withdrawals for 2005 is lower than in previous years (1970-2000). In 2005, 99 public water systems withdrew surface-water supplies of $1 \mathrm{Mgal} / \mathrm{d}$ or more. The largest surface-water withdrawals by public water-supply systems in the State occurred in counties located in the Tennessee and Ohio hydrologic regions and came primarily from the Lower Cumberland (233 Mgal/d), French Broad-Holston (127 Mgal/d), Upper Tennessee (71.0 Mgal/d), and the Middle Tennessee-Hiwassee River Basins (70.9 Mgal/d). Other river basins in Tennessee provided about $88 \mathrm{Mgal} / \mathrm{d}$ of the municipal water supplies in 2005 (table 3).

Surface-water use in 2005 primarily increased in Middle and East Tennessee. Water-supply systems serving the metropolitan Nashville/Davidson County area served more than
545,000 customers in 2005 and withdrew about $130 \mathrm{Mgal} / \mathrm{d}$ from the Cumberland River (Supplement B). This was the largest surface-water withdrawal in the State during 2005. Large amounts of surface water were also withdrawn from the Tennessee River in the Chattanooga and Knoxville metropolitan areas (Supplement A). Surface water was not a primary source for public water-supply systems in the Lower Mississippi hydrologic region of West Tennessee, because of the abundance and availability of groundwater supplies (Hutson and Morris, 1992; Hutson, 1999). The distribution of surfacewater withdrawal rates in Tennessee counties during 2005 is shown in figure 6 . Additional information about surface-water sources and withdrawal rates are presented in Supplements A, $\mathrm{B}$, and $\mathrm{C}$.

\section{Groundwater}

Groundwater supplied about $329 \mathrm{Mgal} / \mathrm{d}$ in 2005 (fig. 4), an increase of approximately $8 \mathrm{Mgal} / \mathrm{d}$ since 2000 . Almost 78 percent of the groundwater withdrawn for public supply during 2005 was reported from West Tennessee. In Shelby County, Tennessee, alone, groundwater withdrawals yielded $188 \mathrm{Mgal} / \mathrm{d}$ (fig. 7) and provided water for more than 881,000 people. The largest total withdrawal $(167 \mathrm{Mgal} / \mathrm{d})$ by a single water system in Tennessee occurred in Memphis by MLGW, which served a population of 654,267. Approximately $252 \mathrm{Mgal} / \mathrm{d}$ of groundwater were withdrawn from the Tertiary sand, Cretaceous sand, and alluvial aquifers (figs. 8 and 9). In contrast to the large amount of groundwater used in West Tennessee, the combined withdrawals from aquifers in Middle and East Tennessee were only about $76 \mathrm{Mgal} / \mathrm{d}$.

Table 3. Surface-water withdrawals from Tennessee river basins in 2005 .

[Withdrawals in million gallons per day]

\begin{tabular}{lc}
\hline \multicolumn{1}{c}{ River basin name } & $\begin{array}{c}\text { Surface-water } \\
\text { withdrawal }\end{array}$ \\
\hline Lower Cumberland & 233 \\
French Broad-Holston & 127 \\
Upper Tennessee & 71.0 \\
Middle Tennessee-Hiwassee & 70.8 \\
Upper Cumberland & 40.3 \\
Lower Tennessee & 35.9 \\
Middle Tennessee-Elk & 11.9 \\
Hatchie-Obion & 0.09 \\
\hline
\end{tabular}




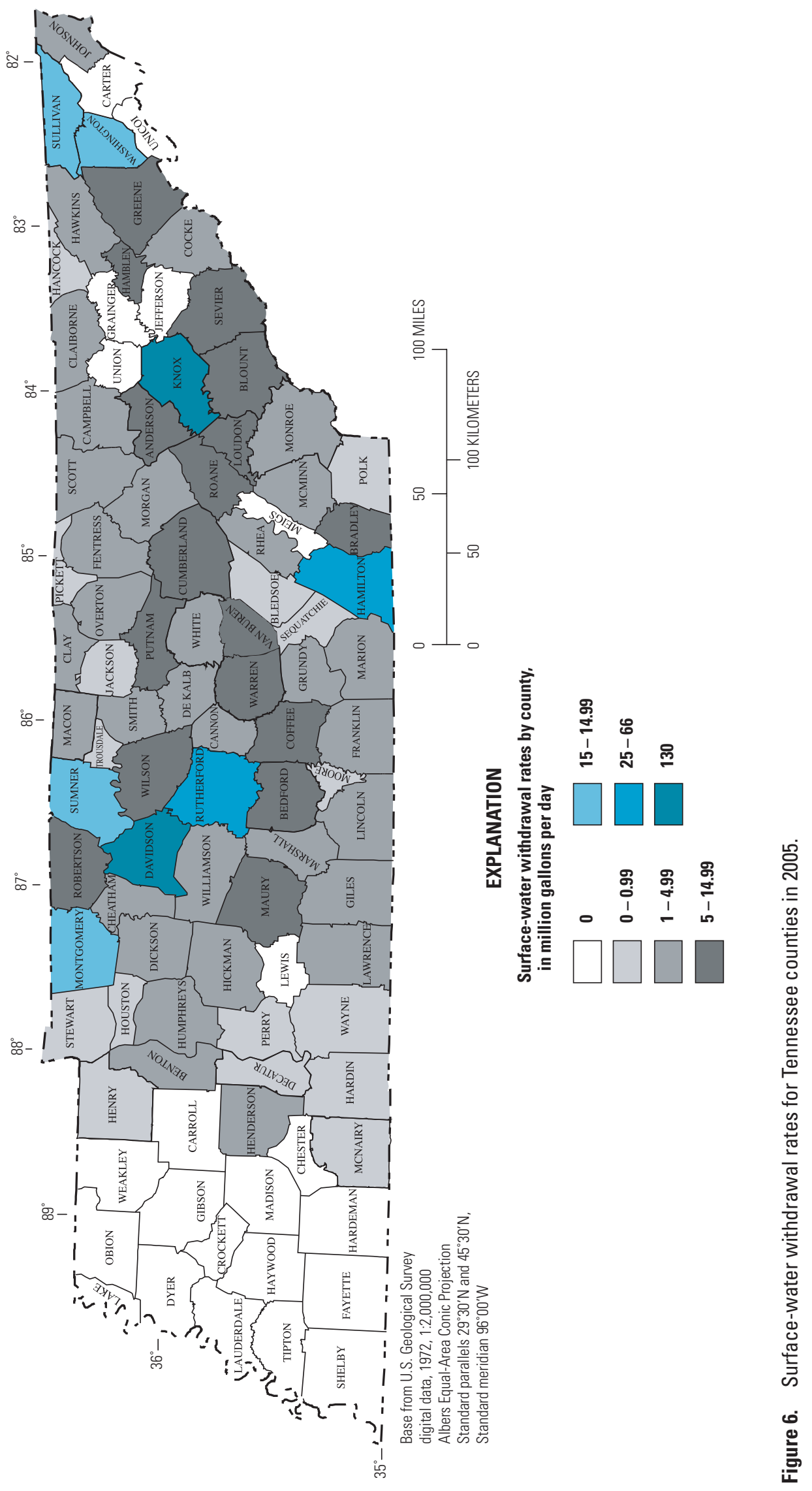


Table 4. Groundwater withdrawals by public water-supply systems in Tennessee using 1 million gallons per day or more.

[-, no groundwater withdrawal reported by system; aquifer names-TRMS, Tertiary sand-Memphis aquifer; TRCF, Tertiary sand-Cockfield aquifer; TRFP, Tertiary sand-Fort Pillow aquifer; CRCS, Cretaceous sand; CMBR, Cambrian-Ordovician carbonate rock; CRYST, Crystalline rock; ALVM, Alluvial; MSSP, Mississippian carbonate; ODVC, Ordovician carbonate rock]

\begin{tabular}{|c|c|c|c|c|c|c|}
\hline \multirow[b]{2}{*}{ Public water-supply system } & \multicolumn{4}{|c|}{ Withdrawal rates, in million gallons per day } & \multirow{2}{*}{$\begin{array}{l}\text { Change in } \\
\text { withdrawals } \\
\text { (1988-2005) }\end{array}$} & \multirow{2}{*}{ Aquifer } \\
\hline & 1988 & 1995 & 2000 & 2005 & & \\
\hline \multicolumn{7}{|c|}{ Lower Mississippi Hydrologic region } \\
\hline Memphis Light, Gas and Water & 141 & 148 & 166.73 & 167.39 & 26.39 & TRMS \\
\hline Jackson Water System & 10.2 & 12.1 & 15.03 & 13.72 & 3.52 & TRMS \\
\hline Germantown Water Department & 4.91 & 3.96 & 7.28 & 6.19 & 1.28 & TRMS \\
\hline $\begin{array}{l}\text { Bartlett Water System/Bartlett- } \\
\text { Ellendale }\end{array}$ & $1.36 / 1.77$ & 4.44 & 5.99 & 6.47 & 5.11 & TRMS \\
\hline Collierville Water Department & 2.37 & 3.41 & 5.82 & 6.06 & 3.69 & TRMS \\
\hline Dyersburg Water Department & 4.35 & 4.12 & 4.00 & 3.22 & -1.13 & TRMS \\
\hline Union City Water Department & 2.85 & 3.45 & 3.96 & 3.96 & 1.11 & TRMS \\
\hline $\begin{array}{l}\text { Gibson Co. Municipal Water } \\
\text { Districts }\end{array}$ & 0.73 & 0.81 & 1.34 & 0.82 & 0.09 & TRMS \\
\hline $\begin{array}{l}\text { Humboldt Utilities Water } \\
\text { Department }\end{array}$ & 1.84 & 2.28 & 2.37 & 1.70 & -0.14 & TRMS \\
\hline Selmer Water System & 2.10 & 2.13 & 2.24 & 2.19 & 0.09 & CRCS \\
\hline Covington Water Department & 1.40 & 1.43 & 2.23 & 2.06 & 0.66 & TRMS \\
\hline Ripley Water System & 1.83 & 1.52 & 2.03 & 1.90 & 0.07 & TRMS \\
\hline Brownsville Water Department & 1.71 & 2.05 & 1.77 & 1.75 & 0.04 & TRMS \\
\hline Poplar Grove Utility District & 0.21 & 1.00 & 1.76 & 1.92 & 1.71 & TRMS \\
\hline Martin Water Department & 1.51 & 1.40 & 1.50 & 1.42 & -0.09 & TRMS \\
\hline Milan Water Department & 1.34 & 1.31 & 1.33 & 1.24 & -0.10 & TRMS \\
\hline County Wide Utility District & 0.96 & 1.13 & 1.01 & 1.01 & 0.05 & $\begin{array}{l}\text { TRMS/ } \\
\text { TRCF }\end{array}$ \\
\hline Bolivar Water System & 1.37 & 1.17 & 1.28 & 1.17 & -0.20 & CRCS \\
\hline McKenzie Water Department & 0.72 & 1.19 & 1.22 & 1.11 & 0.39 & TRFP \\
\hline Henderson Water Department & 0.86 & 1.02 & 1.15 & 1.01 & 0.15 & CRCS \\
\hline Millington Water Department & 1.10 & 1.17 & 1.10 & 0.59 & -0.51 & TRFP \\
\hline Munford Water Department & 0.38 & 0.72 & 1.05 & 1.17 & 0.79 & TRMS \\
\hline Naval Support Activity Memphis & 1.91 & 1.56 & 0.93 & 0.80 & -1.12 & TRFP \\
\hline Newbern Water Department & - & - & - & 1.21 & 1.21 & $\mathrm{TRCF}$ \\
\hline Subtotal & 187.01 & 201.37 & 233.12 & 230.08 & 43.06 & \\
\hline
\end{tabular}


Table 4. Groundwater withdrawals by public water-supply systems in Tennessee using 1 million gallons per day or more-Continued

[-, no groundwater withdrawal reported by system; aquifer names-TRMS, Tertiary sand-Memphis aquifer; TRCF, Tertiary sand-Cockfield aquifer; TRFP, Tertiary sand-Fort Pillow aquifer; CRCS, Cretaceous sand; CMBR, Cambrian-Ordovician carbonate rock; CRYST, Crystalline rock; ALVM, Alluvial; MSSP, Mississippian carbonate; ODVC, Ordovician carbonate rock]

\begin{tabular}{|c|c|c|c|c|c|c|}
\hline \multirow{2}{*}{ Public water-supply system } & \multicolumn{4}{|c|}{ Withdrawal rates, in million gallons per day } & \multirow{2}{*}{$\begin{array}{l}\text { Change in } \\
\text { withdrawals } \\
\text { (1988-2005) }\end{array}$} & \multirow{2}{*}{ Aquifer } \\
\hline & 1988 & 1995 & 2000 & 2005 & & \\
\hline \multicolumn{7}{|c|}{ Tennessee Hydrologic region } \\
\hline Hixson Utility District & 5.61 & 6.19 & 6.70 & 6.54 & 0.93 & CMBR \\
\hline Elizabethton Water Department & 5.26 & 5.35 & 5.39 & 5.70 & 0.44 & CMBR \\
\hline Johnson City Water Department & 3.18 & 3.93 & 3.72 & 3.91 & 0.73 & CRYST \\
\hline Jefferson City Water and Sewer Comm. & 1.51 & 2.34 & 2.70 & 3.88 & 2.37 & CMBR \\
\hline Athens Utilities Board & 1.76 & 1.12 & 2.60 & 3.17 & 1.41 & CMBR \\
\hline Paris Board of Public Utilities & 2.17 & 2.41 & 2.57 & 2.28 & 0.11 & CRCS \\
\hline Savannah Public Utilities Department & 1.73 & 1.60 & 2.27 & 2.26 & 0.53 & ALVM \\
\hline Erwin Utilities & 1.28 & 2.08 & 2.21 & 1.95 & 0.67 & CMBR \\
\hline Lincoln County Board of Public Utilities \#1 & 0.74 & 1.42 & 1.68 & 1.91 & 1.17 & MSSP \\
\hline Savannah Valley Utility District & 0.80 & 0.90 & 1.66 & 2.06 & 1.26 & CMBR \\
\hline Hohenwald Water System & 0.90 & 1.18 & 1.48 & 1.52 & 0.62 & MSSP \\
\hline Ocoee Utility District & 0.56 & 1.47 & 1.33 & 1.41 & 0.85 & CMBR \\
\hline Lawrenceburg Water System & 1.07 & 1.32 & 1.27 & 0.63 & -0.44 & MSSP \\
\hline Cleveland Utilities & 1.25 & 1.47 & 1.23 & 1.14 & -0.11 & CMBR \\
\hline First Utility District of Carter County & 0.76 & 1.06 & 1.12 & 1.90 & 1.14 & CMBR \\
\hline Eastside Utility District & 3.77 & - & - & - & -3.77 & CMBR \\
\hline Jasper Water Department & - & - & - & 1.42 & - & CMBR \\
\hline Waverly Water Department & - & - & - & 1.07 & 1.07 & MSSP \\
\hline Mount Pleasant Water System \#1 & 0.93 & 1.06 & 1.03 & 1.07 & 0.14 & MSSP \\
\hline Sweetwater Utility Board & 1.10 & 0.47 & 0.00 & 0.00 & -1.10 & CMBR \\
\hline Mountain City Water Department & 1.10 & 0.45 & 0.83 & 0.64 & -0.46 & CMBR \\
\hline Subtotal & 35.48 & 35.82 & 39.79 & 44.44 & 7.55 & \\
\hline \multicolumn{7}{|c|}{ Ohio (Cumberland River) Hydrologic Region } \\
\hline Fort Campbell Water System & 4.98 & 4.69 & 4.42 & 4.90 & -0.08 & MSSP \\
\hline Lafayette Water System & 0.64 & 0.81 & 1.48 & 0.76 & 0.12 & MSSP \\
\hline Gladeville Utility District \#1 & - & 0.97 & 1.06 & 1.44 & 1.44 & ODVC \\
\hline Subtotal & 5.62 & 6.47 & 6.96 & 7.09 & 1.48 & \\
\hline Totals Statewide & 228.11 & 243.66 & 279.87 & 281.61 & 52.09 & \\
\hline
\end{tabular}




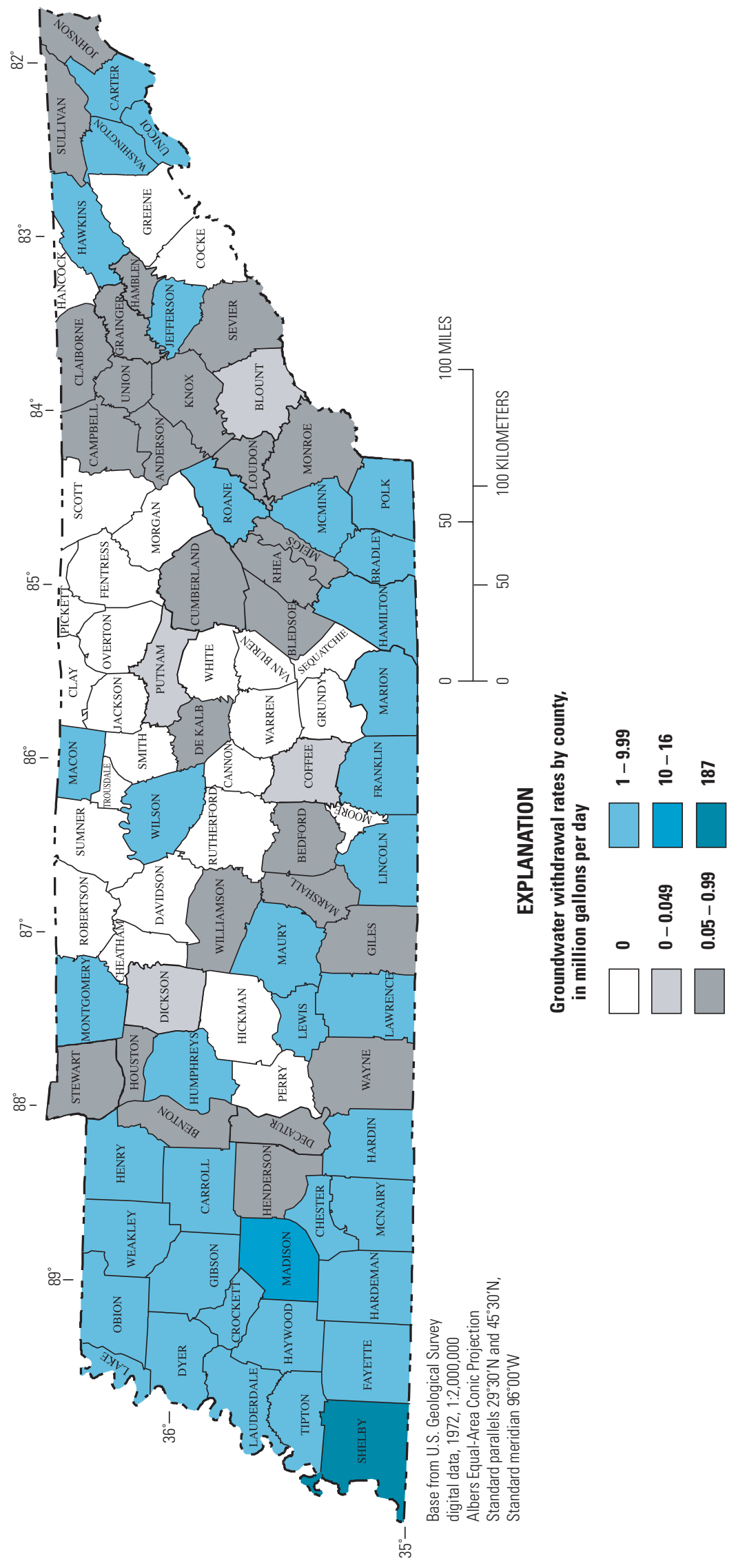

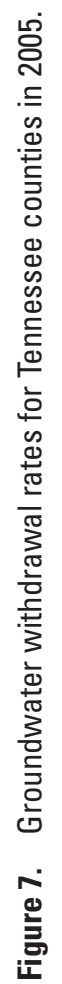




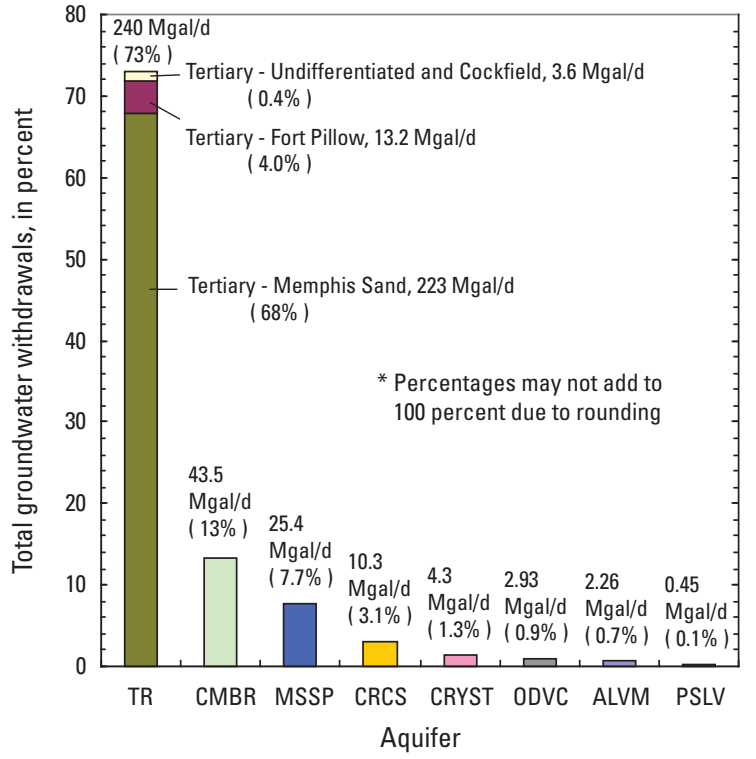

EXPLANATION

Aquifer name

\begin{tabular}{|c|c|c|c|}
\hline TR & Tertiary sand & CRYST & Crystalline rock \\
\hline CMBR & $\begin{array}{l}\text { Cambrian-Ordovician } \\
\text { carbonate }\end{array}$ & ODVC & $\begin{array}{l}\text { Ordovician carbonate } \\
\text { rock }\end{array}$ \\
\hline & Mississippian carbonate & ALVM & Alluvial \\
\hline CRCS & Cretaceous sand & PSLV & $\begin{array}{l}\text { Pennsylvanian } \\
\text { sandstone }\end{array}$ \\
\hline
\end{tabular}

Figure 8. Groundwater withdrawals, in million gallons per day, from principal aquifers in Tennessee in 2005.

A review of historical groundwater use reported by large public water-supply systems withdrawing $1 \mathrm{Mgal} / \mathrm{d}$ or more in Tennessee from 1988 through 2005 indicates that, within the 18-year period, several of these systems substantially increased their withdrawal rates (table 4). Thirty-four systems reported increased withdrawals in 2005, and 15 of these systems increased withdrawals by more than $1 \mathrm{Mgal} / \mathrm{d}$. The greatest total increase in withdrawal rates was reported by systems located in the Lower Mississippi hydrologic region of West Tennessee (43.1 Mgal/d). More than 50 percent (about $167 \mathrm{Mgal} / \mathrm{d}$ ) of the groundwater withdrawals in this region in 2005 were by MLGW, which reported an increase of about $26 \mathrm{Mgal} / \mathrm{d}$ in withdrawals since 1988.

\section{Summary}

In 2005, public water-supply systems provided approximately $920 \mathrm{Mgal} / \mathrm{d}$ of non-purchased surface water and groundwater to the population in Tennessee. Public water supplies in Tennessee came from 144 systems that withdrew about $591 \mathrm{Mgal} / \mathrm{d}$ of surface water and 235 systems that withdrew about $329 \mathrm{Mgal} / \mathrm{d}$ of groundwater, with 16 systems withdrawing from both sources. A separate source category for supply is water purchased from other systems.

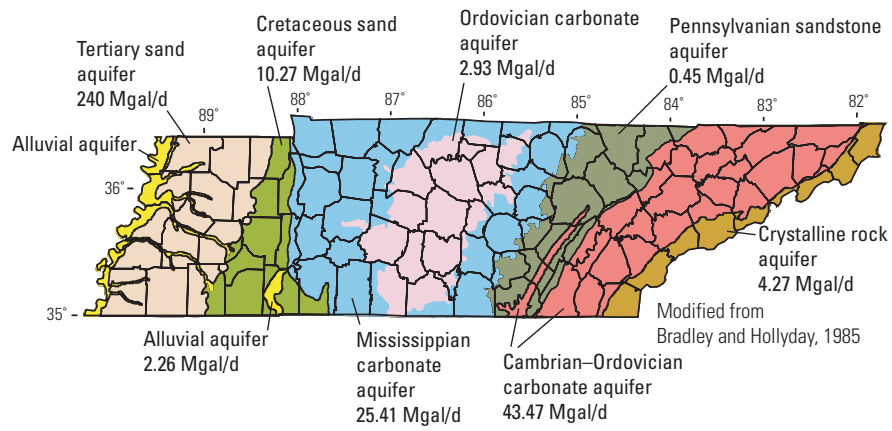

Figure 9. Principal aquifers in Tennessee and rate of water withdrawal, in million gallons per day, 2005.

Tennessee water-supply systems purchased about $88 \mathrm{Mgal} / \mathrm{d}$ of their water from other systems in 2005. The largest surface-water withdrawals by public water-supply systems in the State occurred in counties located in the Tennessee and Ohio hydrologic regions and came primarily from the Lower Cumberland (233 Mgal/d), French Broad-Holston River Basin (127 Mgal/d), Upper Tennessee (71.0 Mgal/d), and the Middle Tennessee-Hiwassee River Basins (70.9 Mgal/d). Other river basins in Tennessee provided about $88 \mathrm{Mgal} / \mathrm{d}$ of the municipal water supplies in 2005.

The sources of water used for public water supplies in Tennessee are directly related to the diversity of the physiographic and hydrologic regions across the State. Surface water is the primary source for water systems in Middle and East Tennessee. In West Tennessee, groundwater is the primary source for public water supply systems. The Tertiary sand aquifers supply about 73 percent of the State's potable groundwater withdrawals.

Historical data available for public water use in Tennessee from 1950 to 2005 indicate that surface-water and ground-water withdrawals have increased significantly. During this period, surface water provided most of the public water supplies in Tennessee. Within the last 5 years, surfacewater withdrawals have increased more than groundwater withdrawals. Since 1988, the number of public water-supply systems distributing water supplies for the State has declined; however, the number of systems distributing only groundwater supplies has increased during the same time period. 


\section{References}

Alexander, F.M., Keck, L.A., Conn, L.G., and Wentz, S.J., 1984, Drought-related impacts on municipal and major selfsupplied industrial water withdrawals in Tennessee-Part B: U.S. Geological Survey Water-Resources Investigations Report 84-4074, 398 p.

Bradley, M.W., and Hollyday, E.F., 1985, Tennessee groundwater resources, in National Water Summary 1980Hydrologic events, selected water-quality trends, and ground-water resources: U.S. Geological Survey WaterSupply Paper 2275, p. 391-396.

Brahana, J.V., and Bradley, M.W., 1985, Delineation and description of regional aquifers of TennesseeThe Knox aquifer in central and West Tennessee: U.S. Geological Survey Water-Resources Investigations Report 83-4012, 32 p.

Brahana, J.V., Macy, J.A., Mulderink, Dolores, and Zemo, Dawn, 1986, Preliminary delineation and description of the regional aquifers of Tennessee-Cumberland Plateau aquifer system: U.S. Geological Survey Water-Resources Investigations Report 82-338, 24 p.

Brahana, J.V., Mulderink, Dolores, and Bradley, M.W., 1986, Preliminary delineation and description of the regional aquifers of Tennessee-The Cretaceous aquifer system of West Tennessee: U.S. Geological Survey Water-Resources Investigations Report 83-4039, 20 p.

Brahana, J.V., Mulderink, Dolores, Macy, J.A., and Bradley, M.W., 1986, Preliminary delineation and description of the regional aquifers of Tennessee-The East Tennessee aquifer system: U.S. Geological Survey Water-Resources Investigations Report 82-4091, 30 p.

Fenneman, N.M., 1946, Physical divisions of the United States: U.S. Geological Survey map, scale 1:7,000,000.

Gonthier, G.J., 2000, Water quality in the deep tertiary aquifers of the Mississippi Embayment, 1996: U.S. Geological Survey Water-Resources Investigations Report 99-4131, $91 \mathrm{p}$.

Hollyday, E.F., and Bradley, M.W., 1985, Tennessee groundwater resources, in National water summary 1984: Hydrologic events, selected water-quality trends, and groundwater resources: U.S. Geological Survey Water-Supply Paper 2275, $467 \mathrm{p}$.

Hutson, S.S., 1989, Ground-water use by public-supply systems in Tennessee in 1985: U.S. Geological Survey WaterResources Investigations Report 89-4092, 1 sheet.

Hutson, S.S., 1990, Tennessee water supply and use, in National water summary 1987-Hydrologic events and water supply and use: U.S. Geological Survey Water-Supply Paper 2350, p. 467-474.
Hutson, S.S., 1991, Ground-water use by public-supply systems in Tennessee in 1988: U.S. Geological Survey OpenFile Report 91-176, 1 sheet.

Hutson, S.S., 1999, Public water-supply systems and associated water use in Tennessee, 1995: U.S. Geological Survey Water-Resources Investigations Report 99-4052, 91 p.

Hutson, S.S., and Morris, A.J., 1992, Public water-supply systems and water use in Tennessee, 1988: U.S. Geological Survey Water-Resources Investigations Report 91-4195, $74 \mathrm{p}$.

Kingsbury, J.A., and Parks, W.S., 1993, Hydrogeology of the principal aquifers and relation of faults to interaquifer leakage in the Memphis area, Tennessee: U.S. Geological Survey Water-Resources Investigations Report 93-4075, 18 p.

MacKichan, K.A., 1951, Estimated use of water in the United States, 1950: U.S. Geological Survey Circular 115, 13 p.

MacKichan, K.A., 1957, Estimated use of water in the United States, 1955: U.S. Geological Survey Circular 398, 18 p.

Miller, R.A., 1974, The geology history of Tennessee: Tennessee Division of Geology Bulliten 74, 63 p.

Murray, C.R., and Reeves, E.B., 1972, Estimated use of water in the United States in 1970: U.S. Geological Survey Circu$\operatorname{lar} 676,37 \mathrm{p}$.

Murray, C.R., and Reeves, E.B., 1977, Estimated use of water in the United States in 1975: U.S. Geological Survey Circu$\operatorname{lar} 765,39 \mathrm{p}$.

Parks, W.S., and Carmichael, J.K., 1989, Geology and groundwater resources of the Fort Pillow Sand in western Tennessee: U.S. Geological Survey Water Resources Investigations Report 89-4120, 20 p.

Solley, W.B., Pierce, R.R., and Perlman, H.W., 1993, Estimated use of water in the United States in 1990: U.S. Geological Survey Circular 1081, 76 p.

Tennessee Department of Environment and Conservation, Division of Water Supply, 2007; unpublished data on file in the USGS Tennessee Water Science Center office, updated by the U.S. Geological Survey in 2007.

U.S. Census Bureau, 2006, State and county quickfactsTennessee, accessed July 16, 2007, at http://factfinder. census.gov/.

U.S. Geological Survey, 1978, Public water supply, chapter 11, accessed January 27, 2009, at http://pubs.usgs.gov/ chapter11/chapter11C.html.

Webbers, Ank, 2003, Public water supply systems and associated water use in Tennessee, 2000: U.S. Geological Survey Water-Resources Investigations Report 03-4264, 90 p. 
Supplement A-Public water-supply systems and associated water use in the Tennessee hydrologic region 


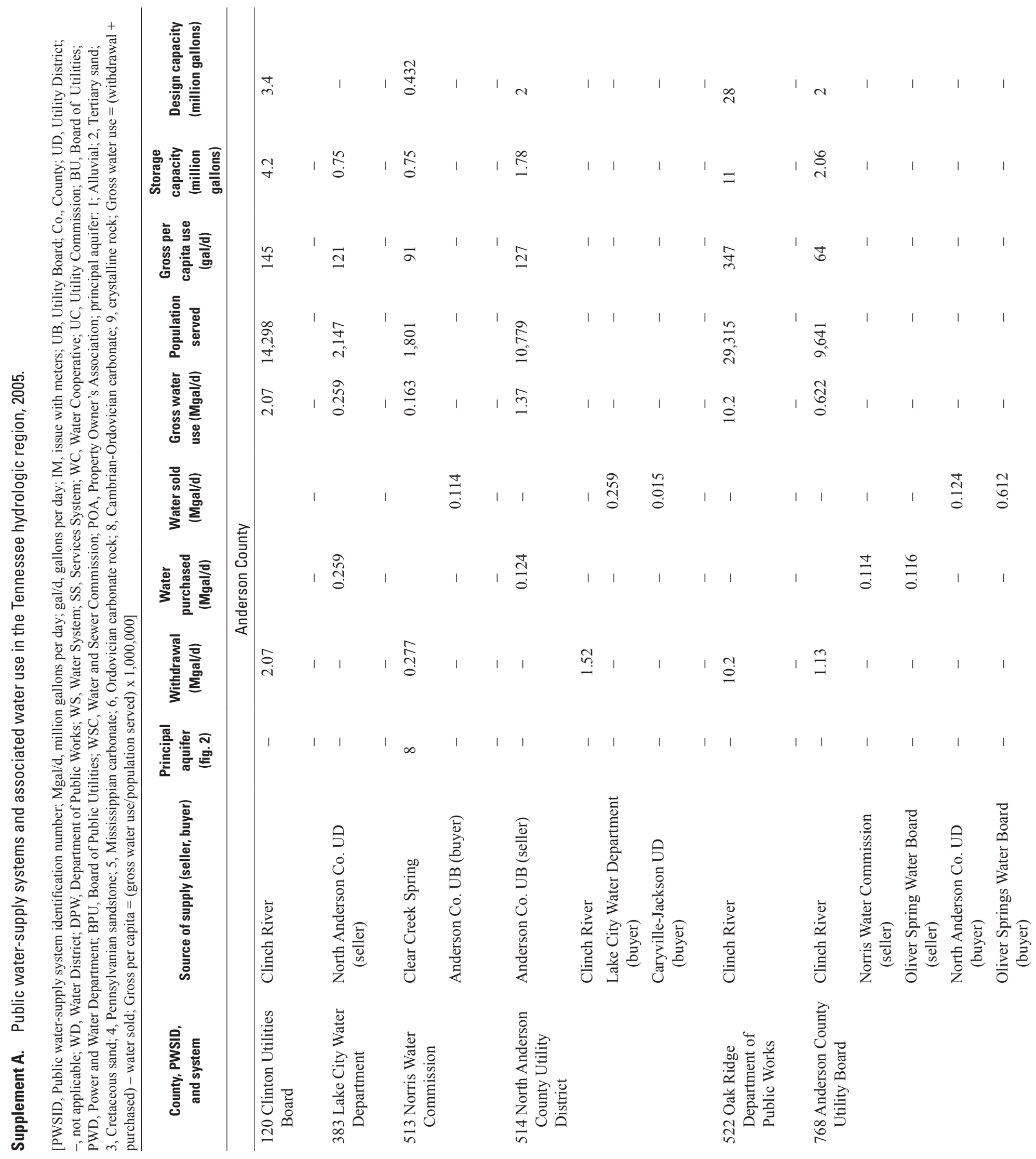




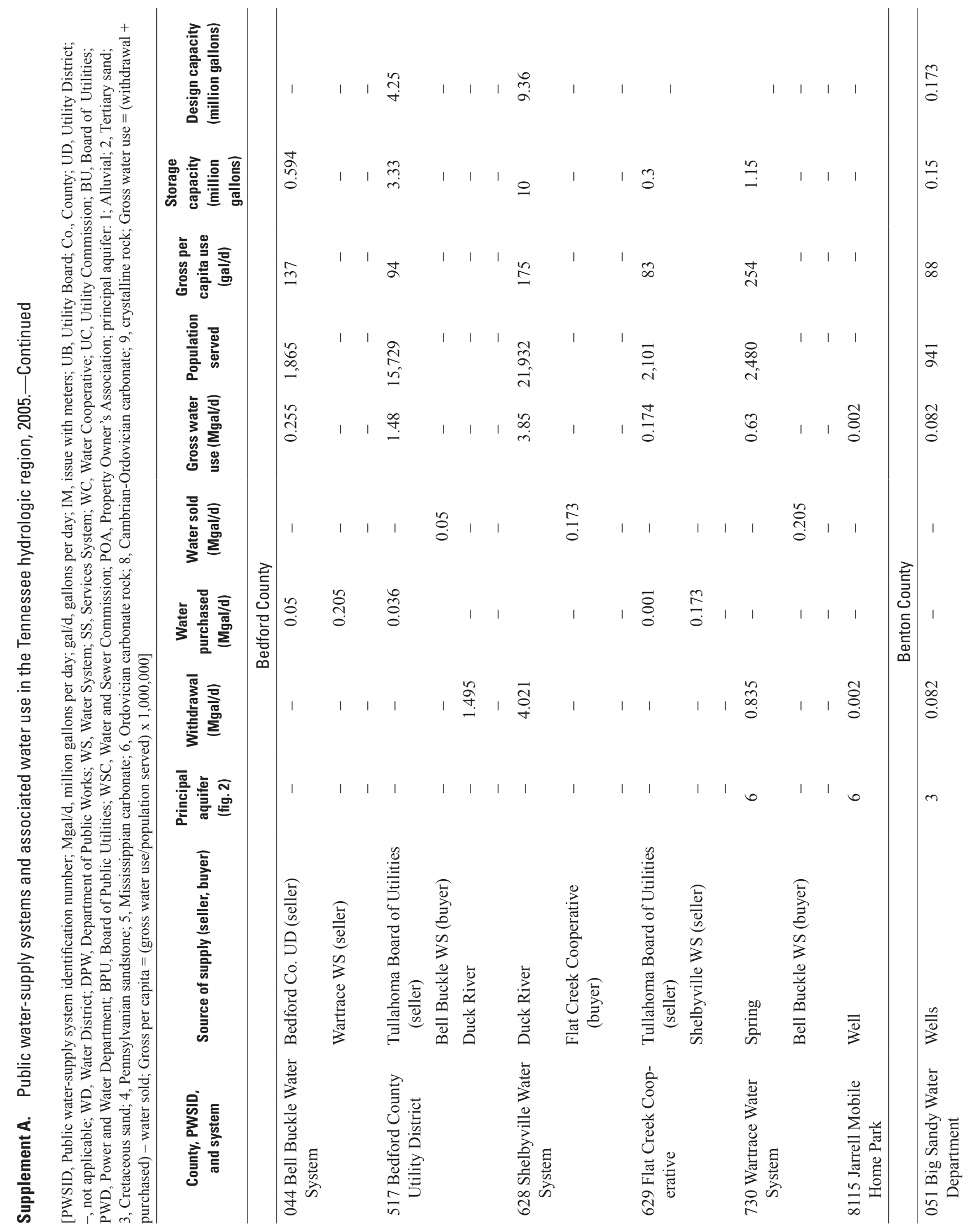




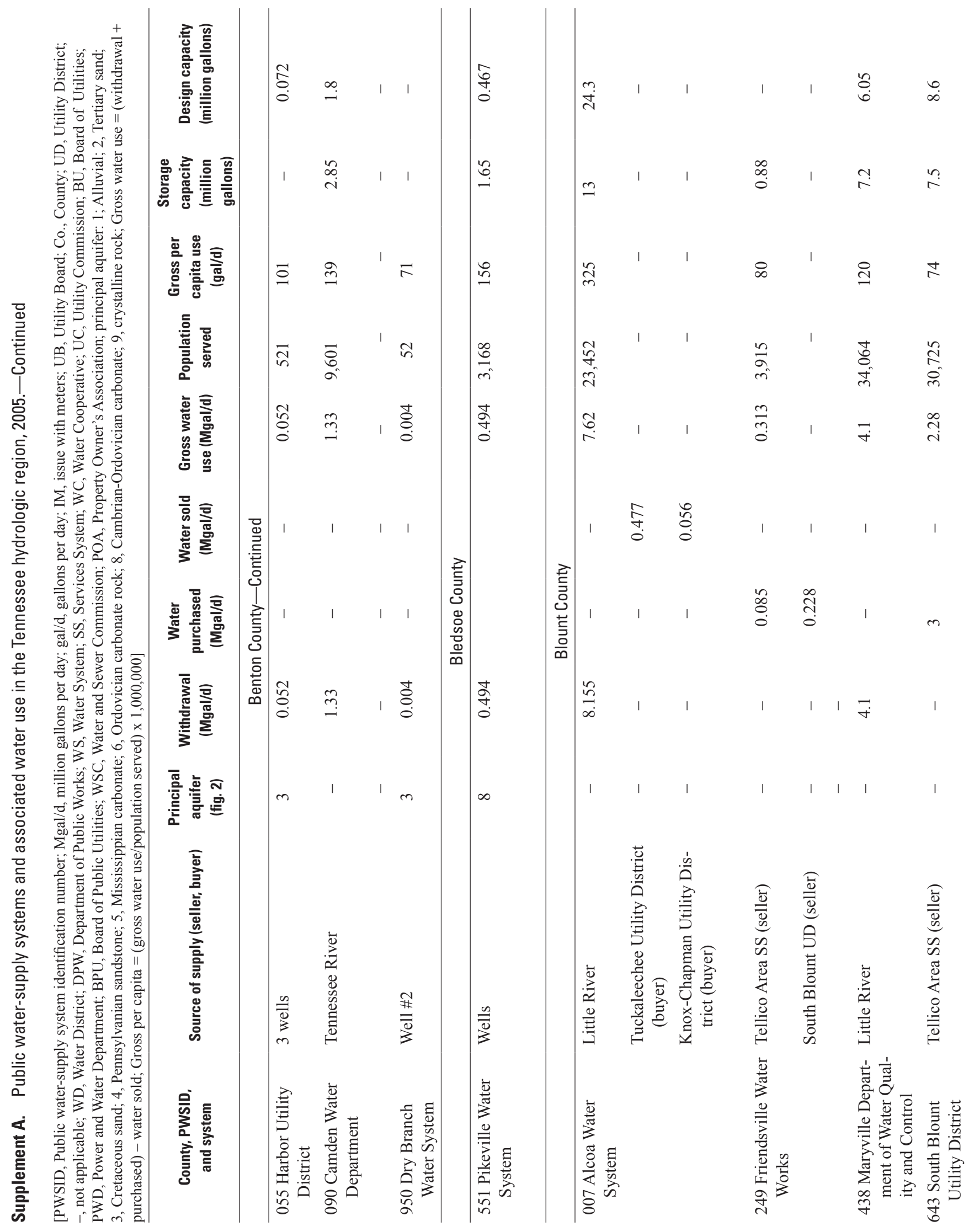




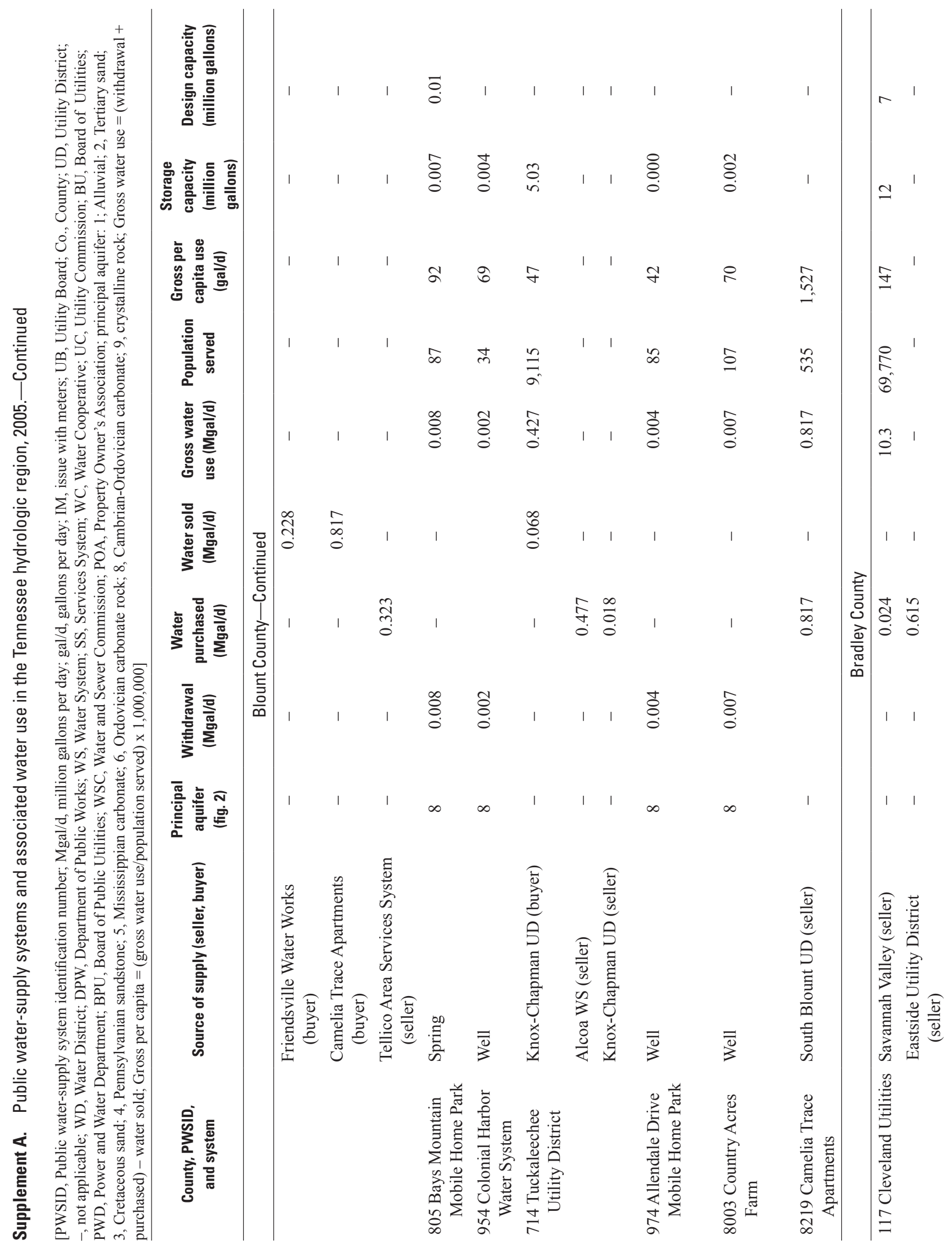




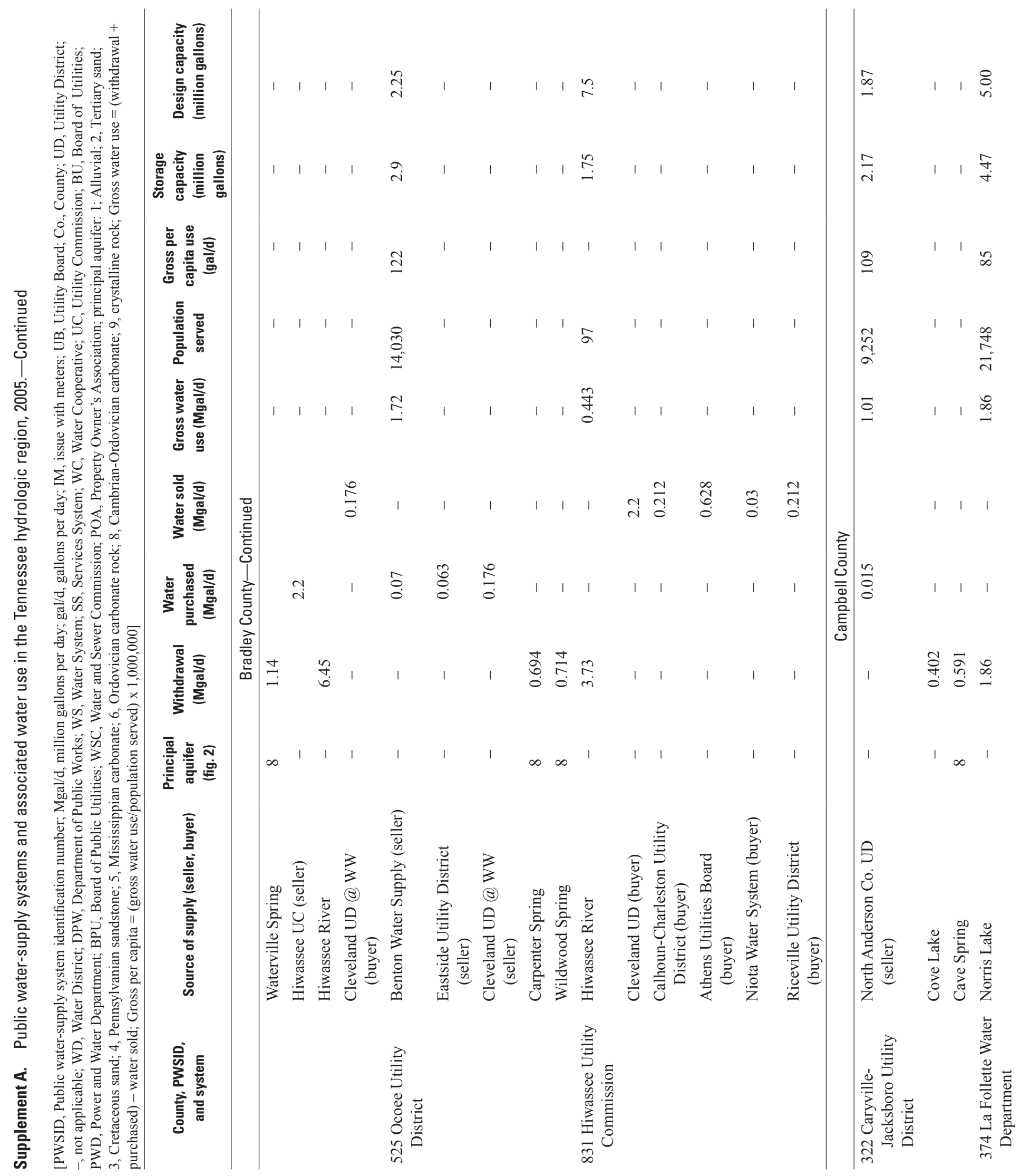




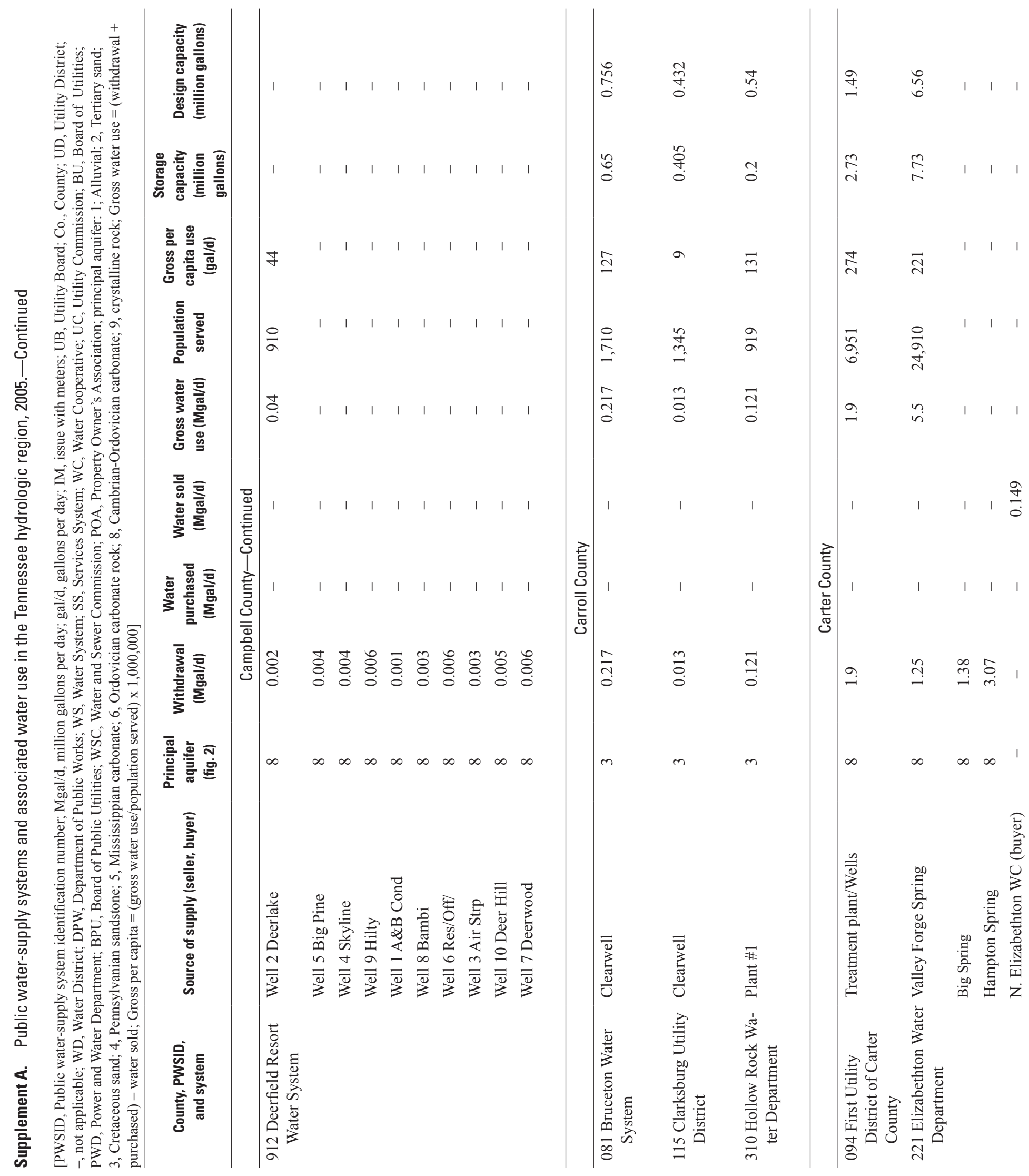




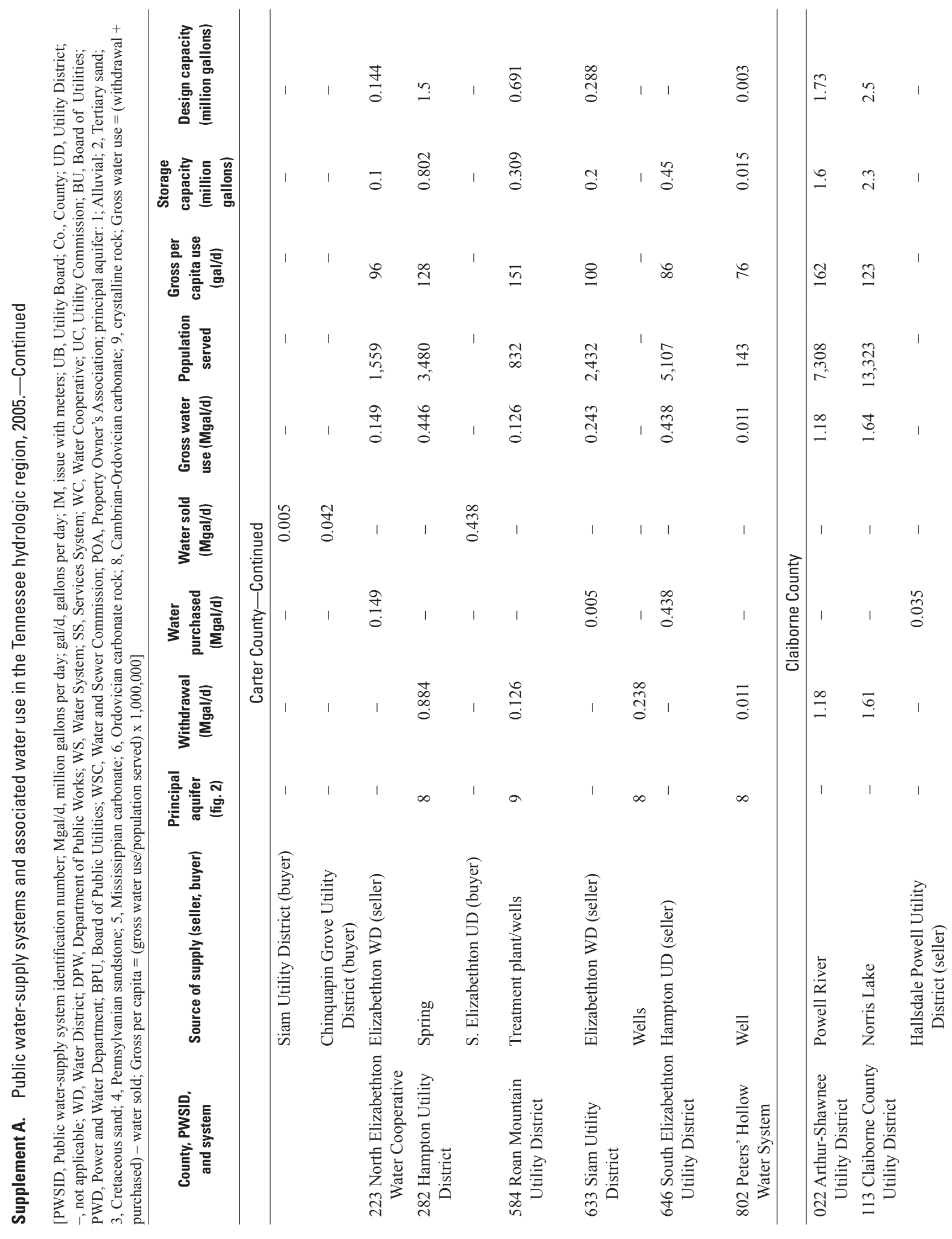




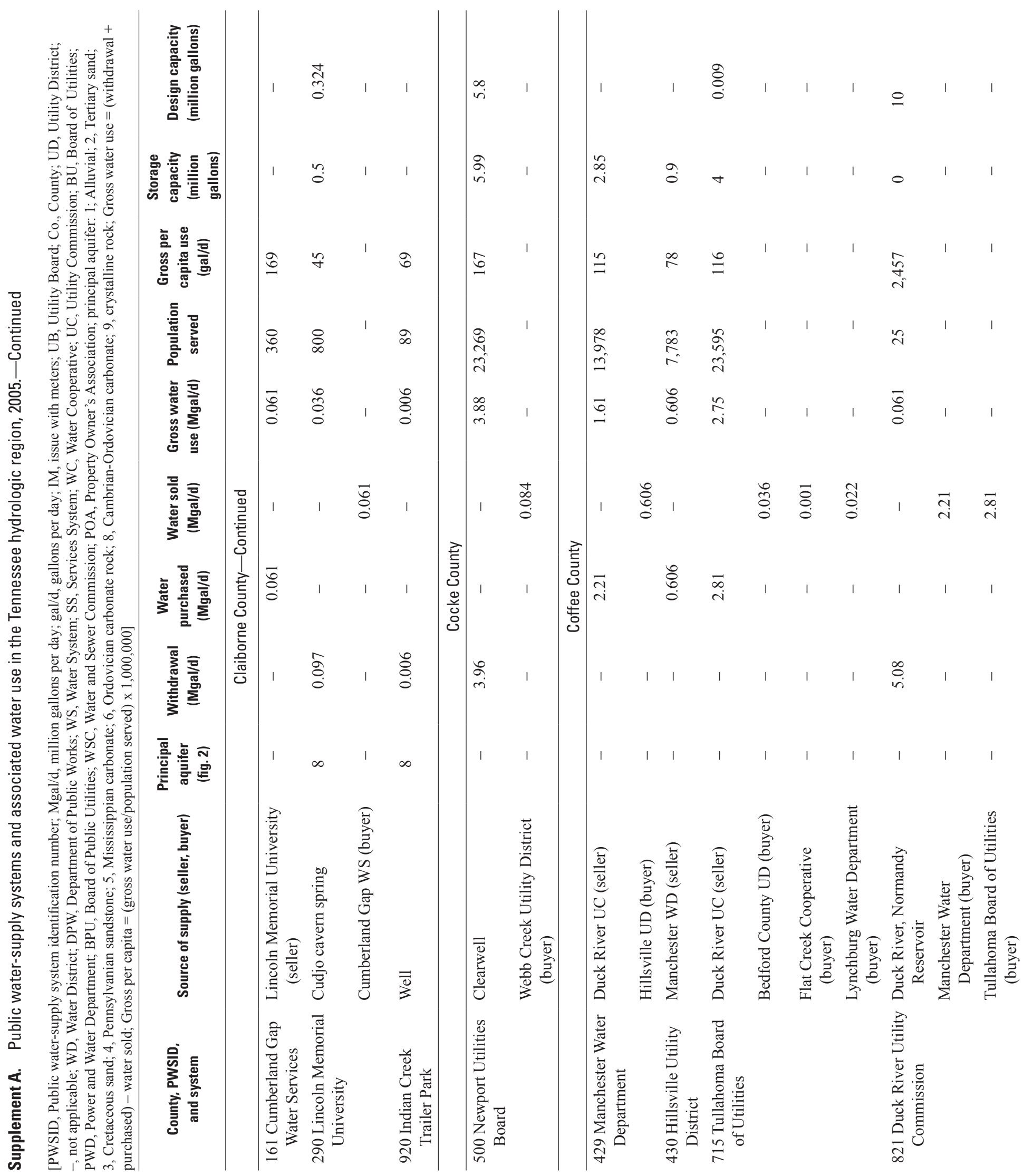




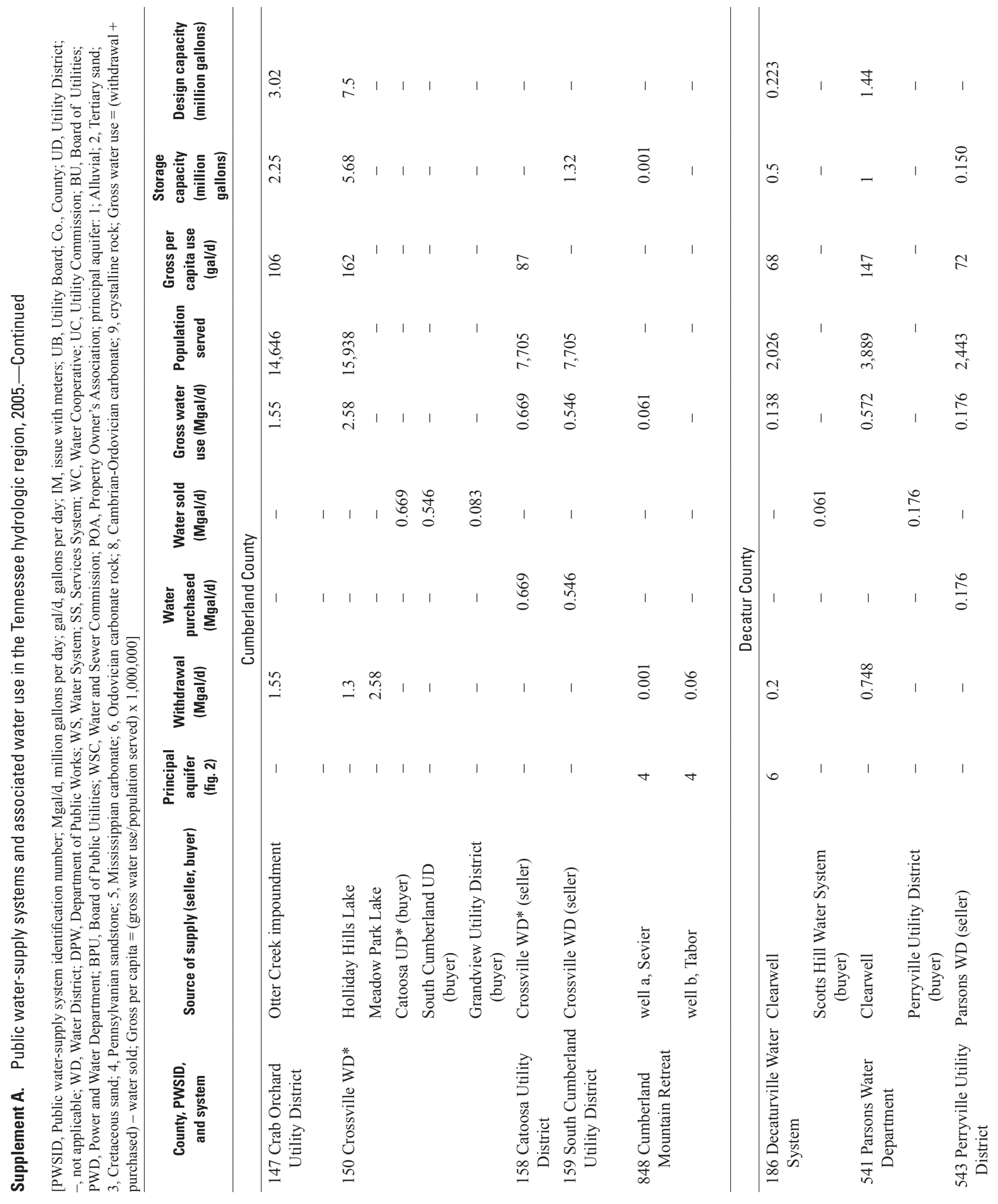




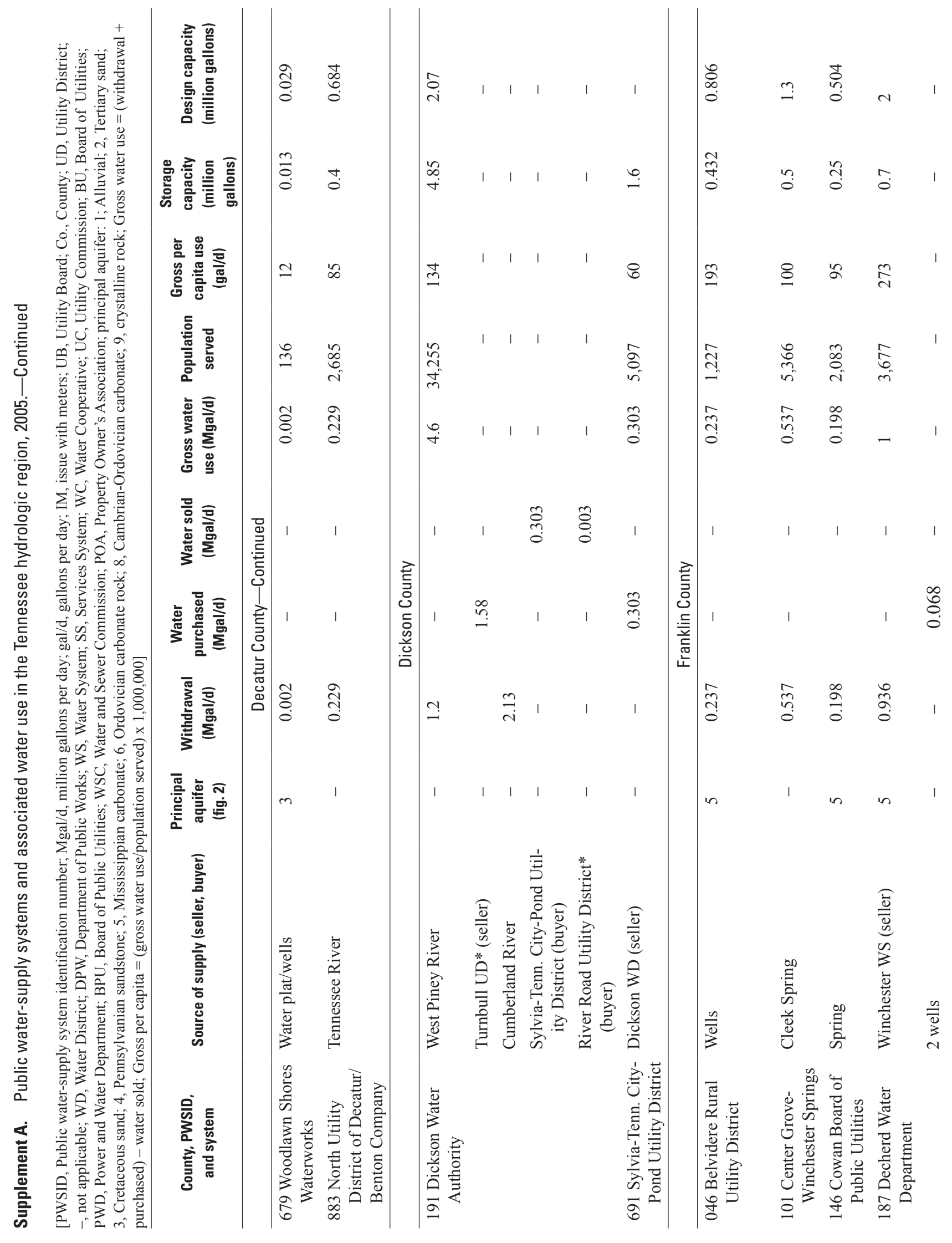




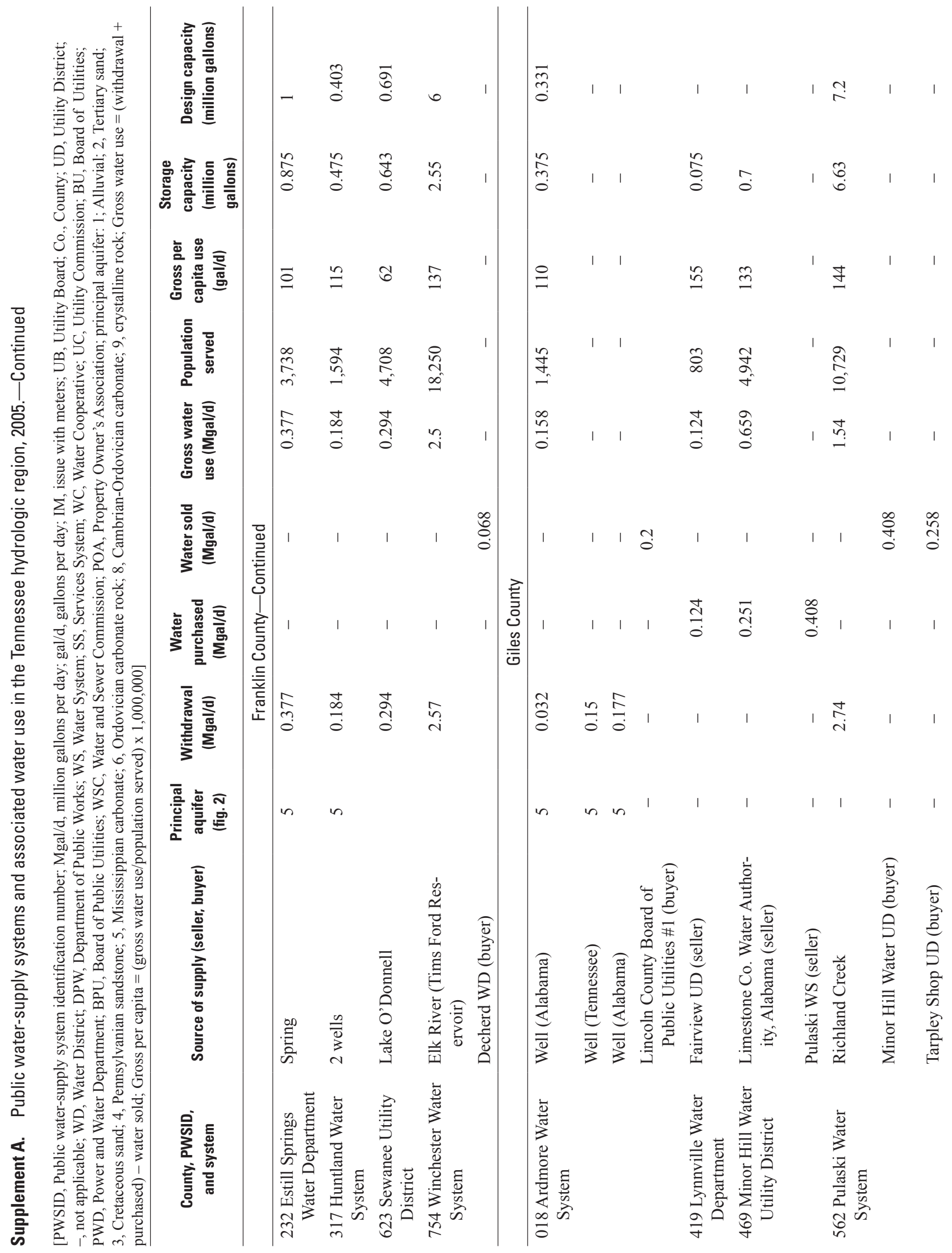




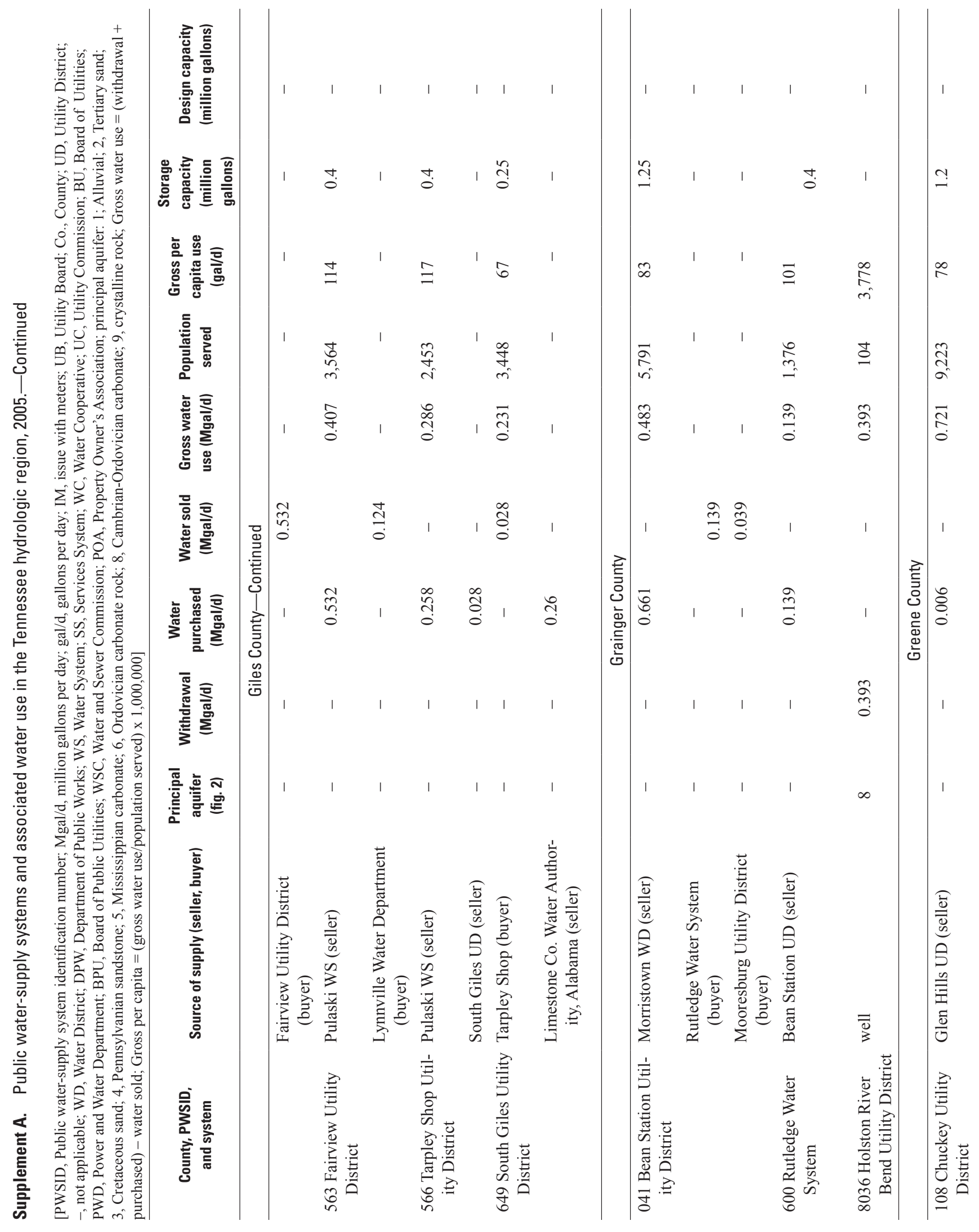




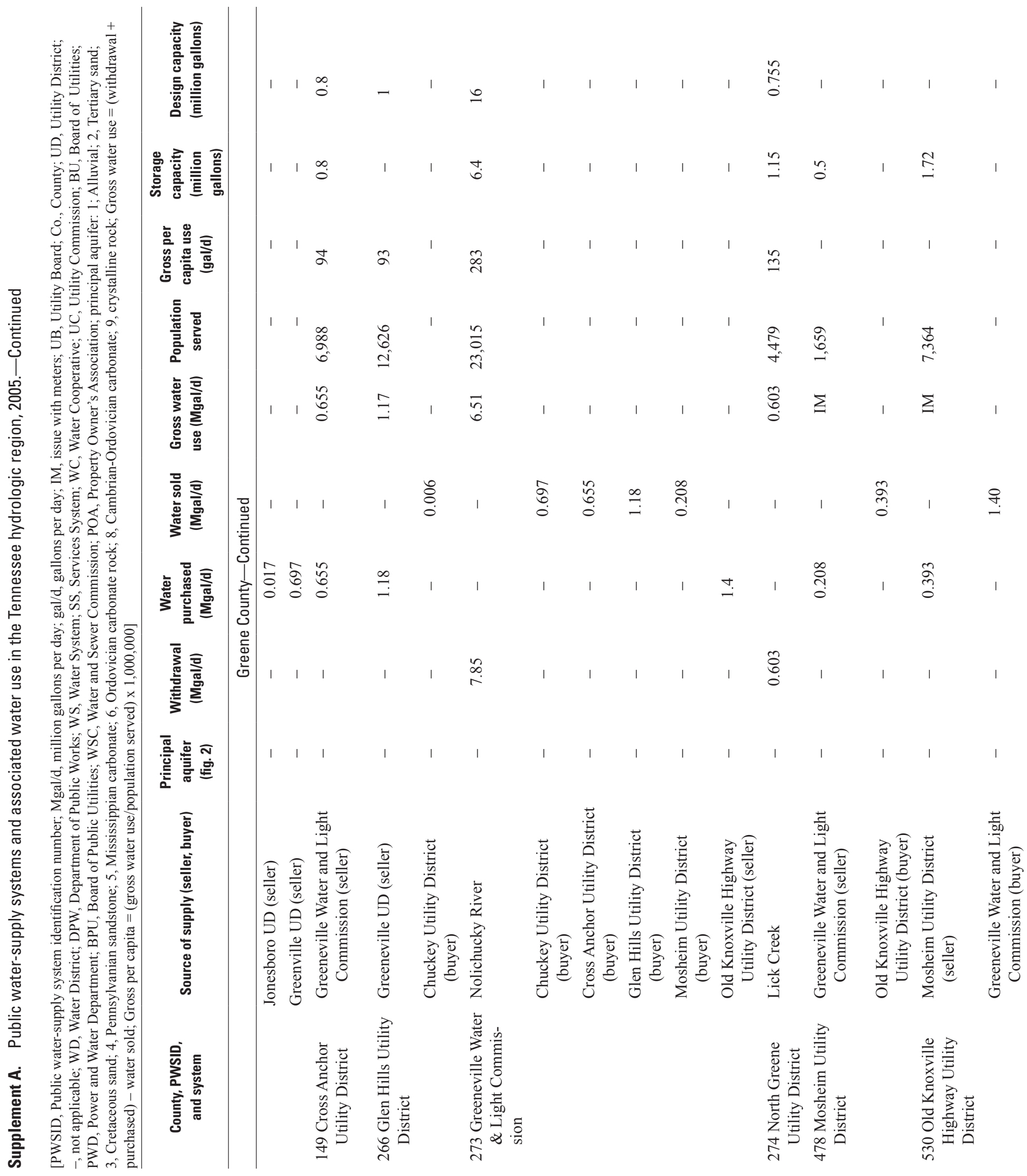




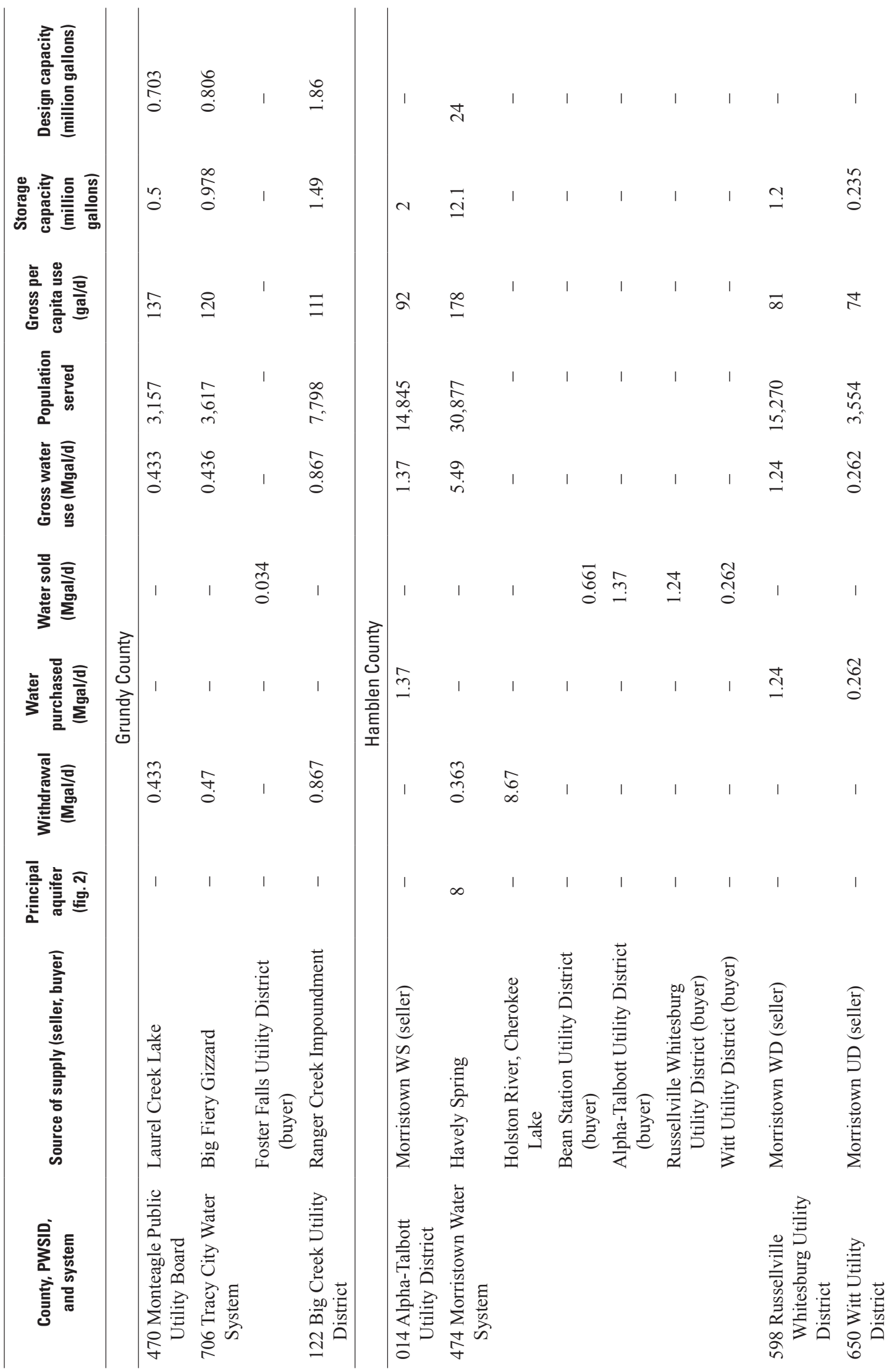




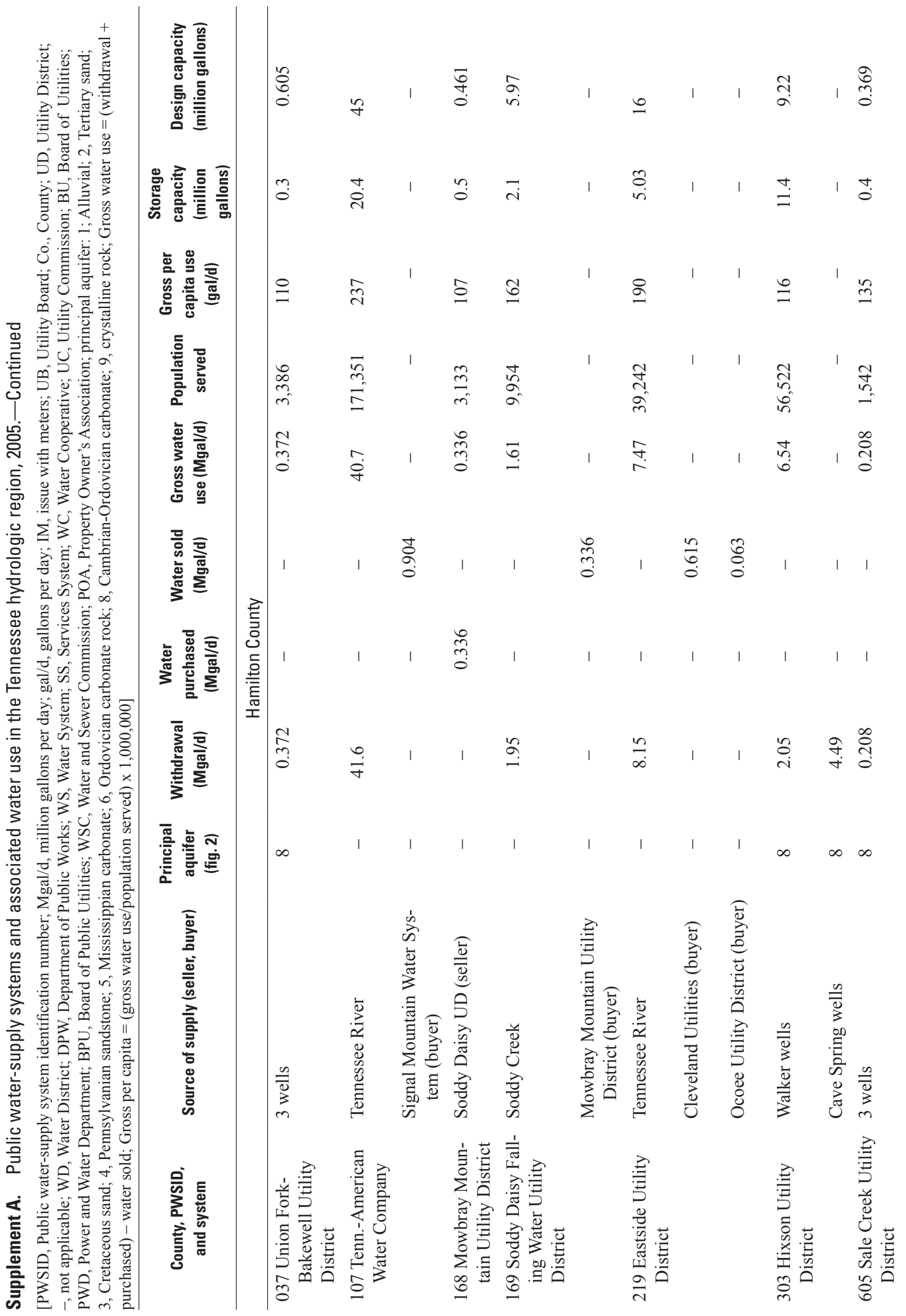



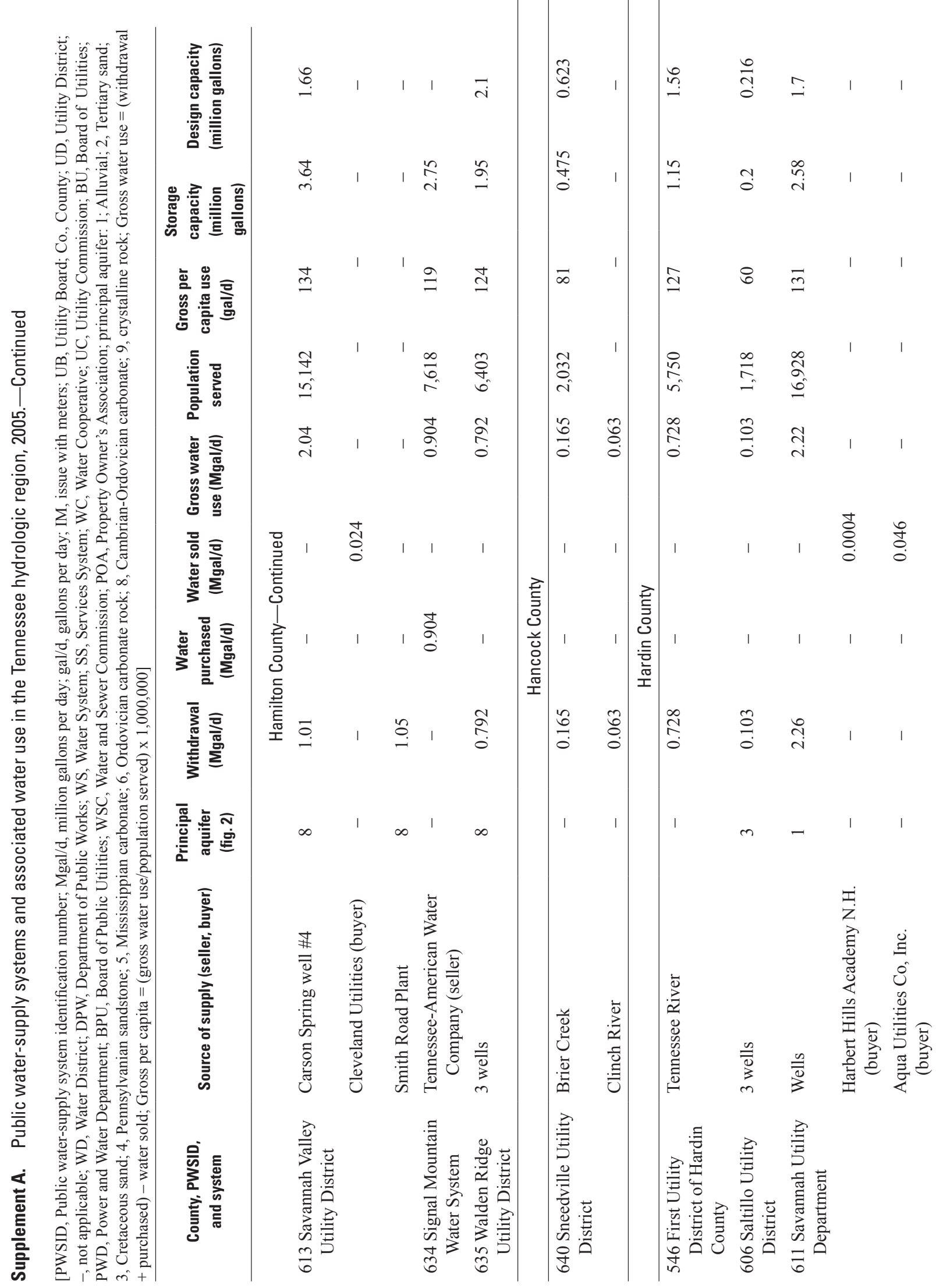


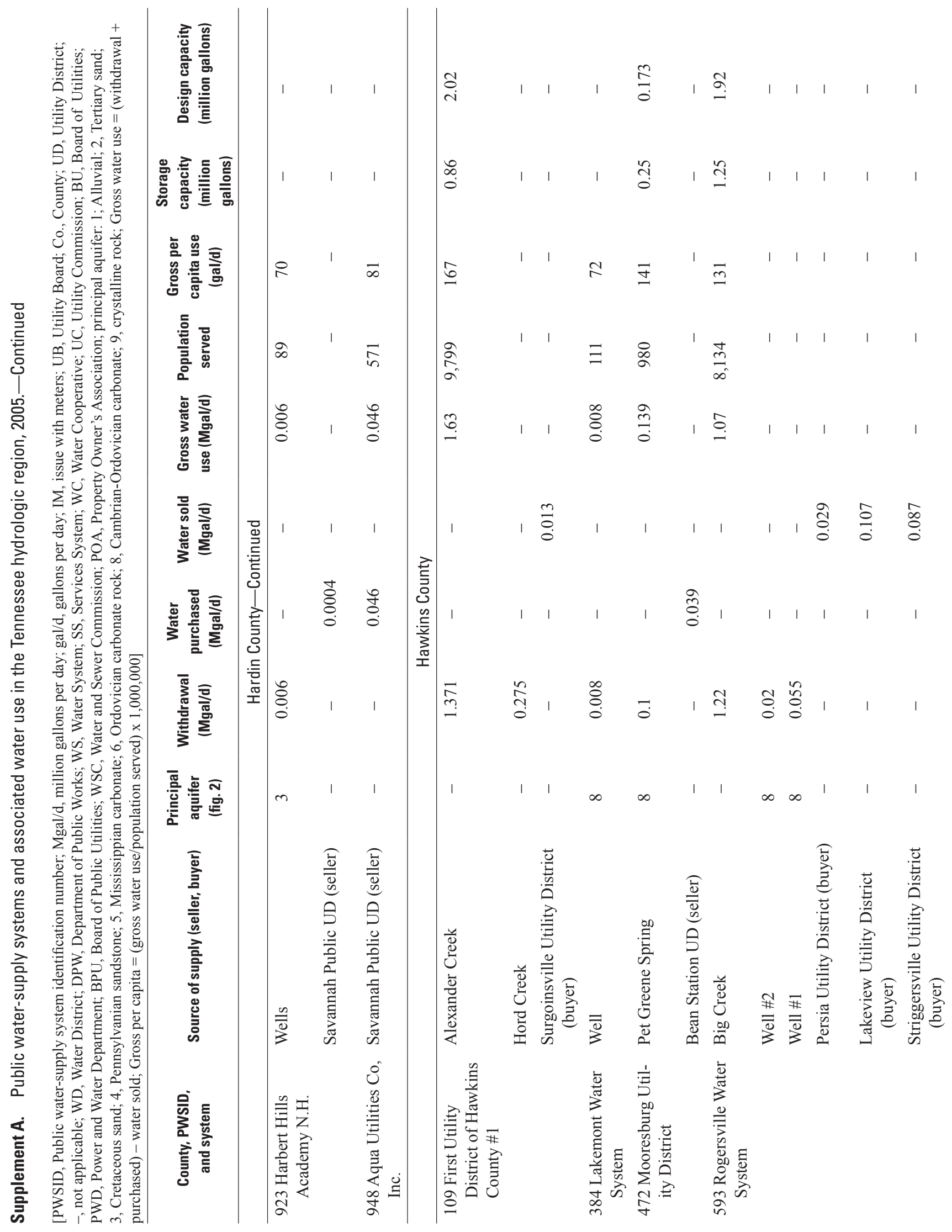




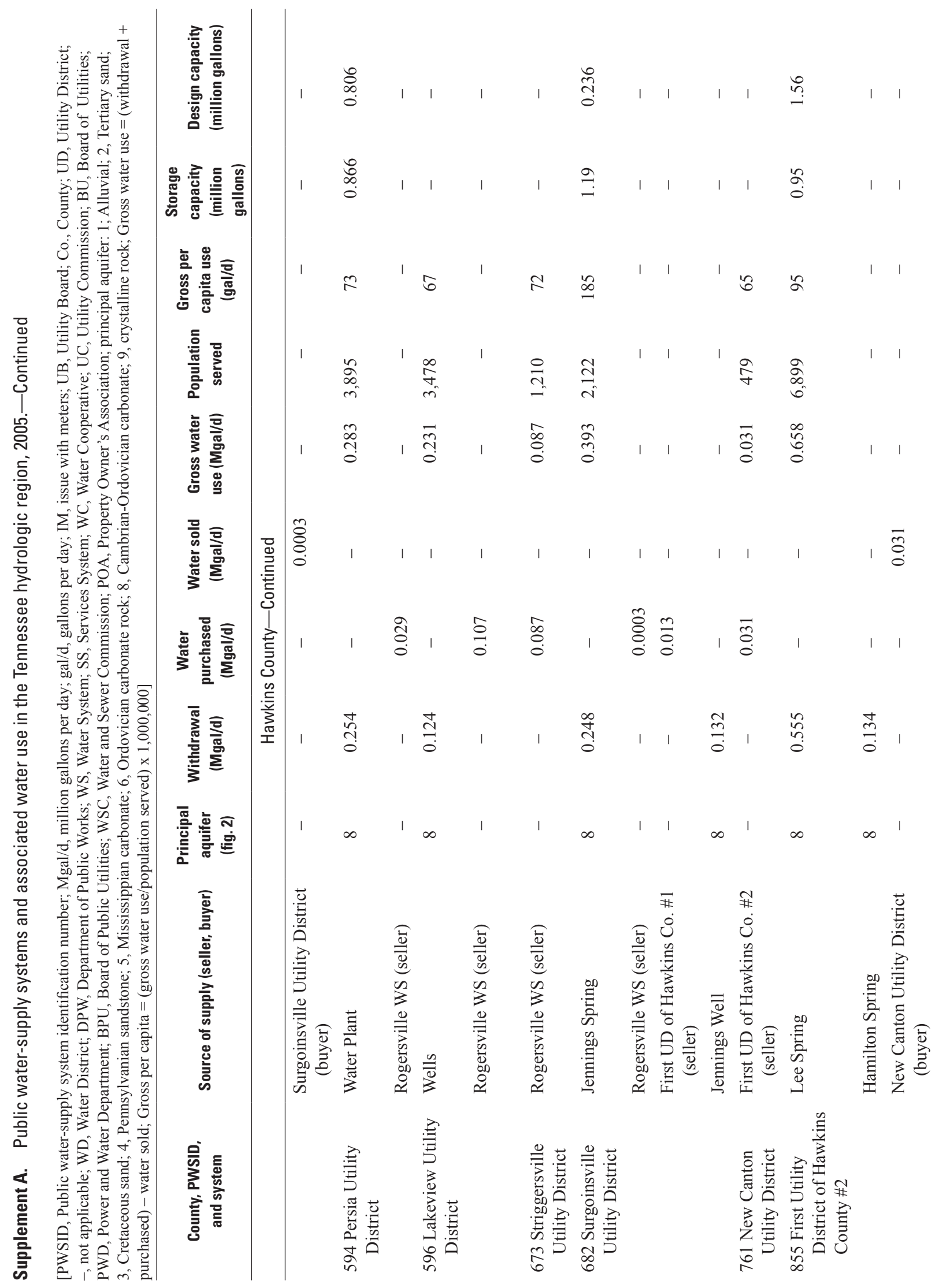




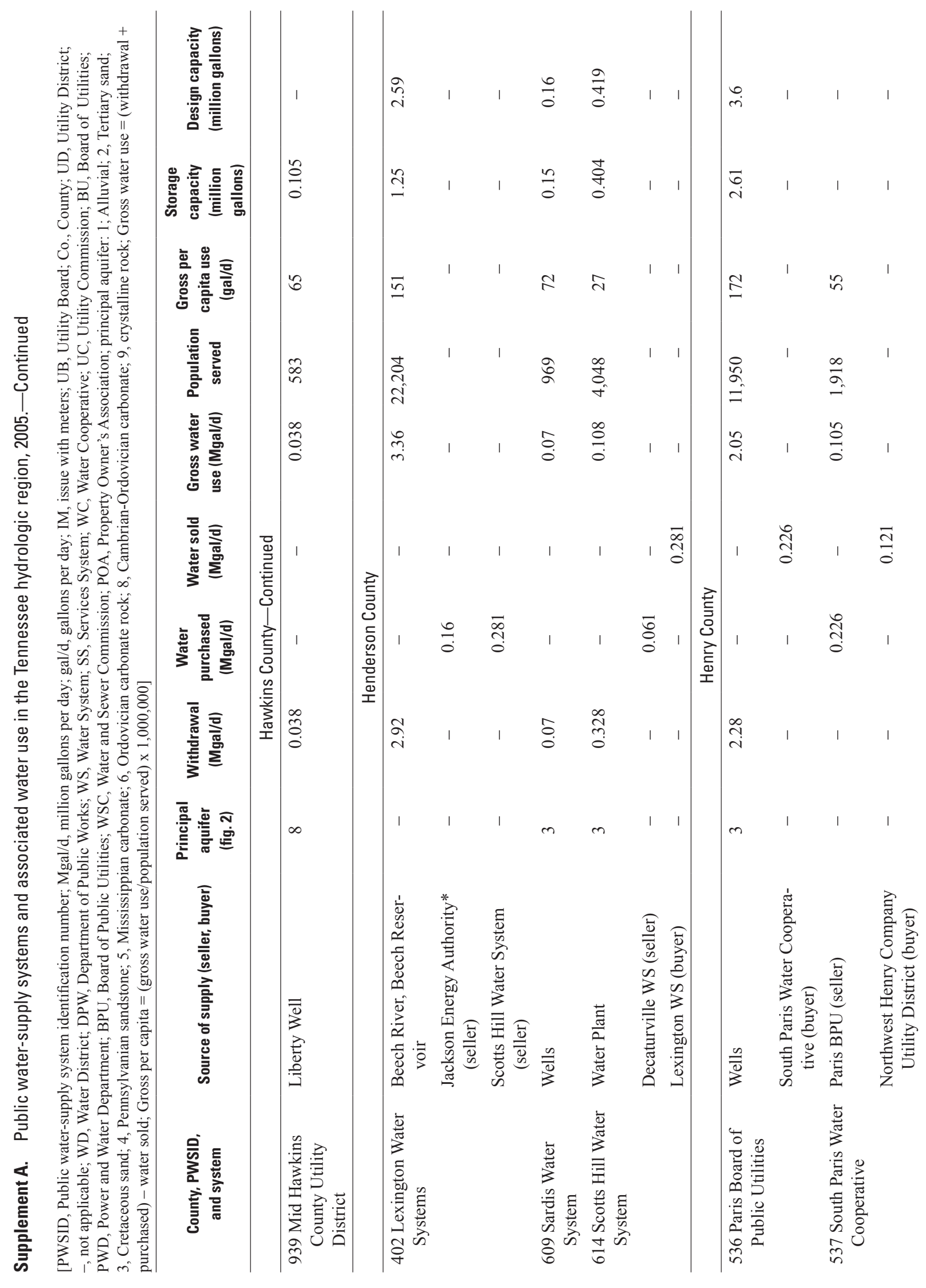



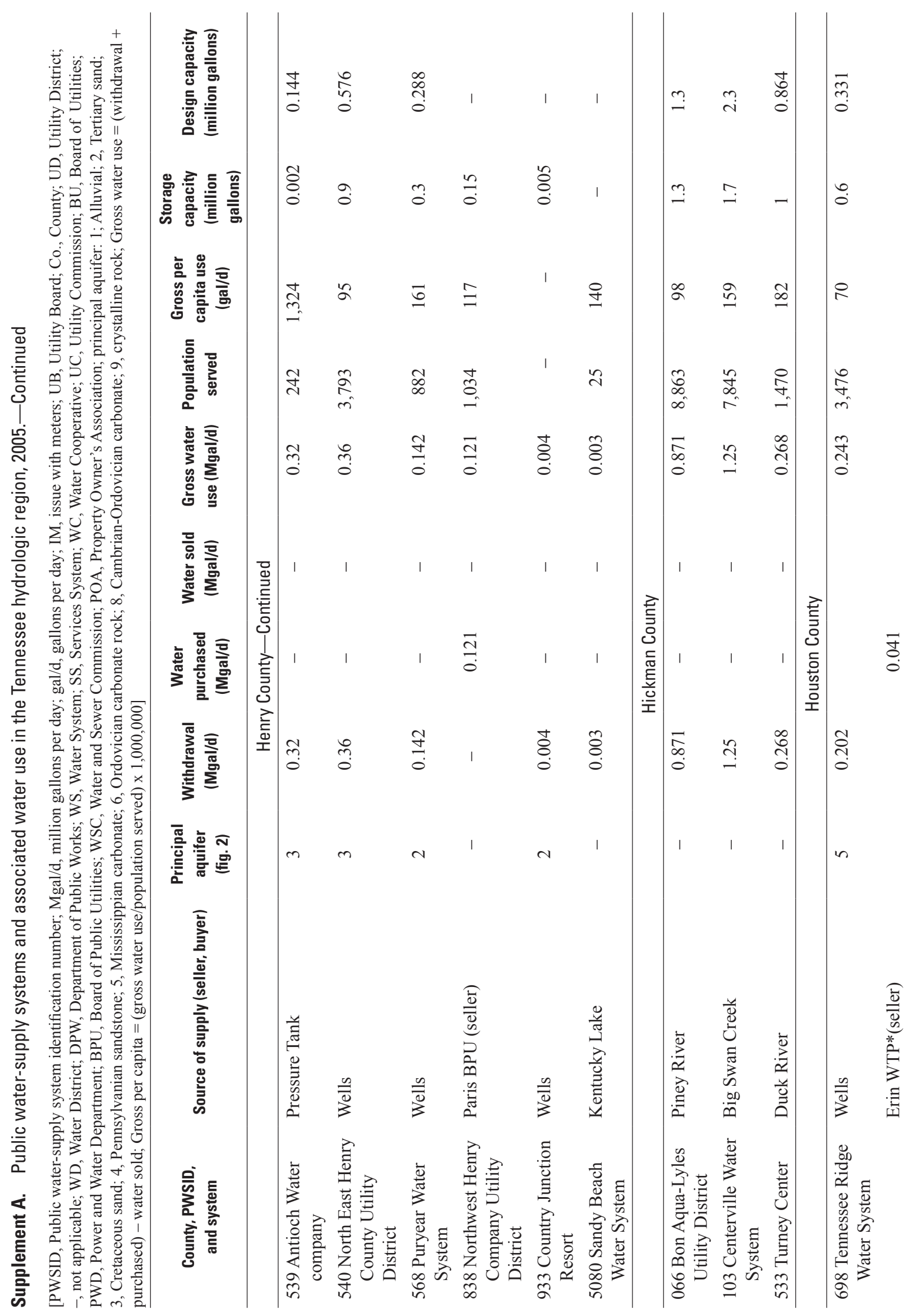


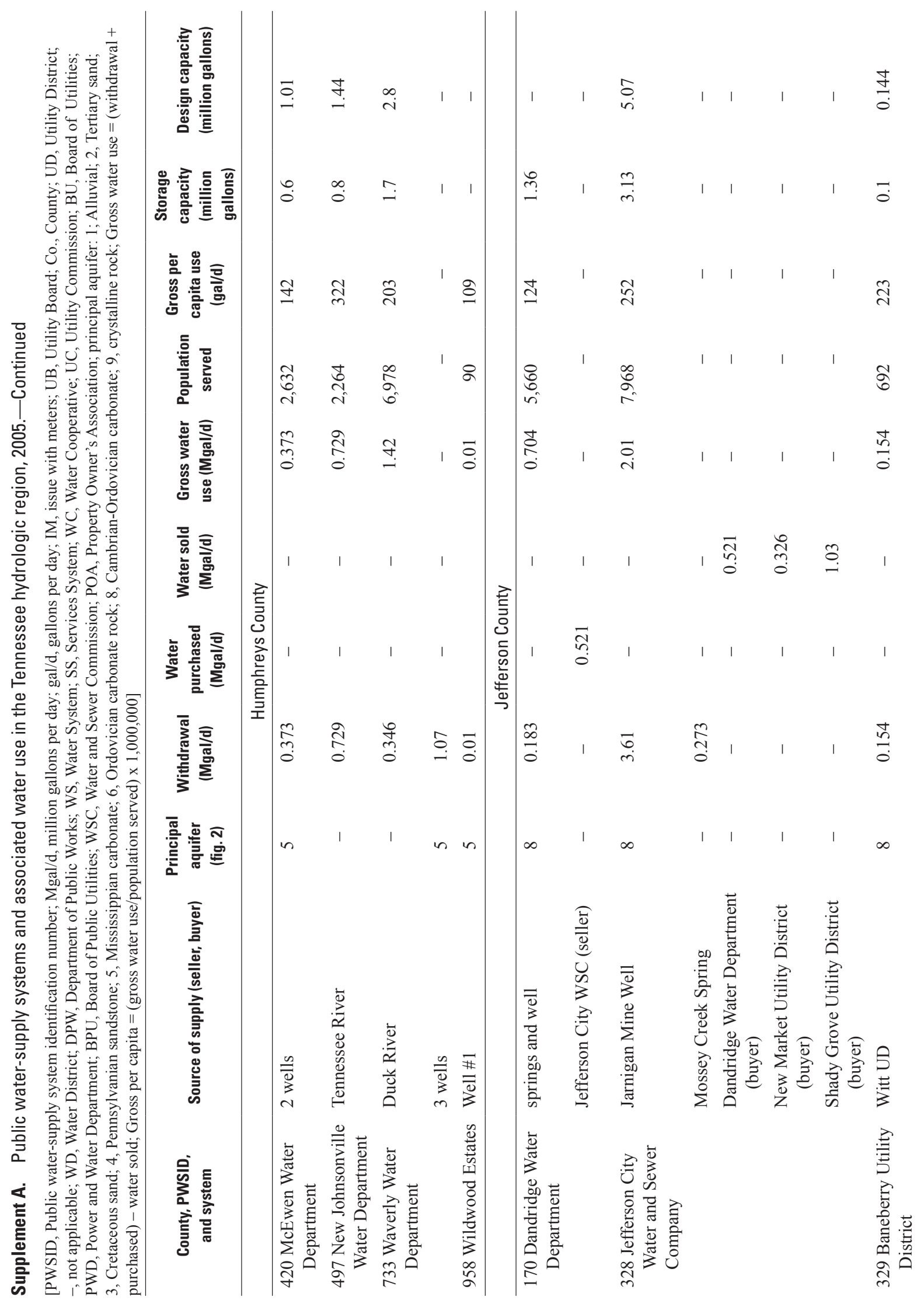



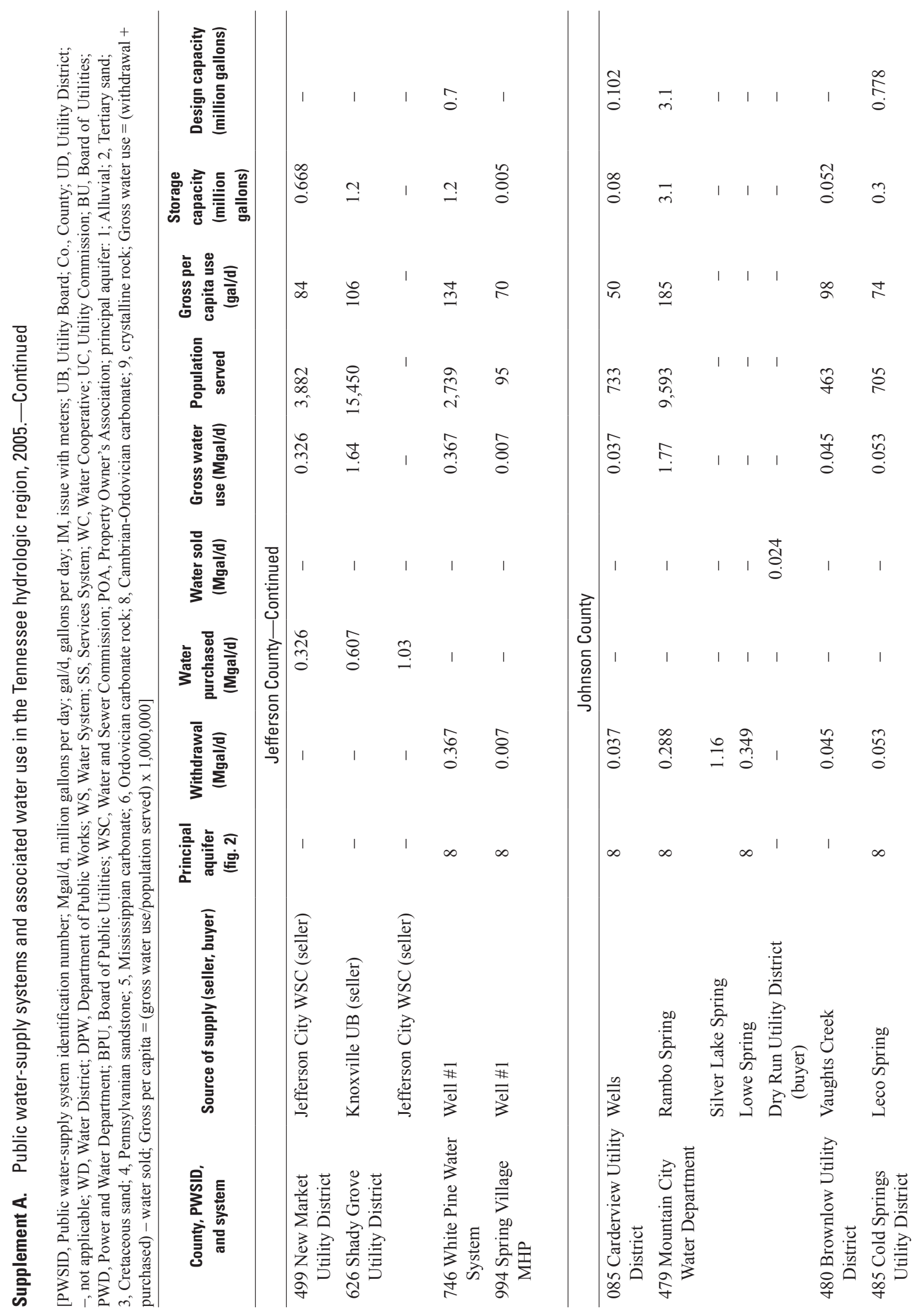


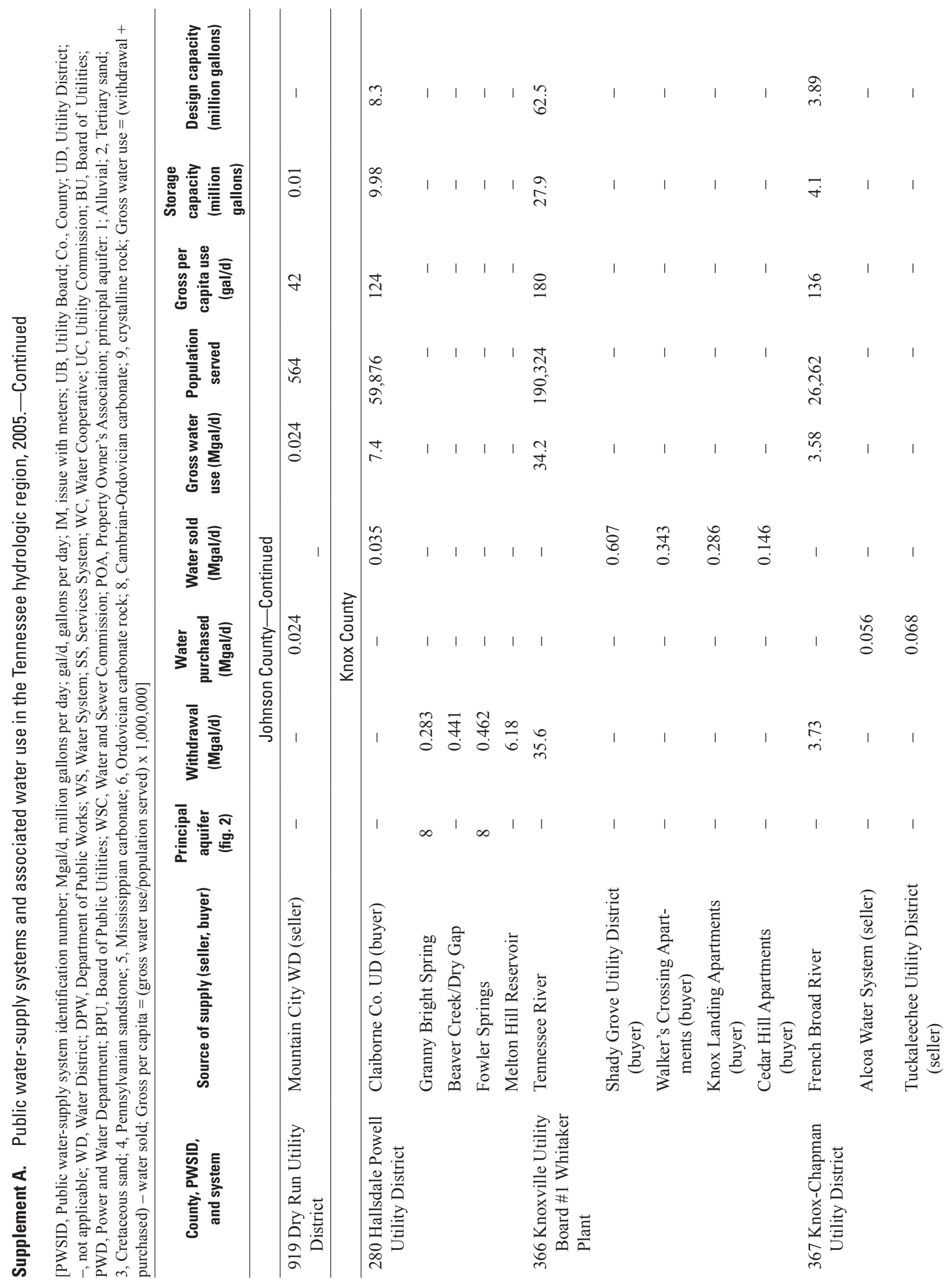




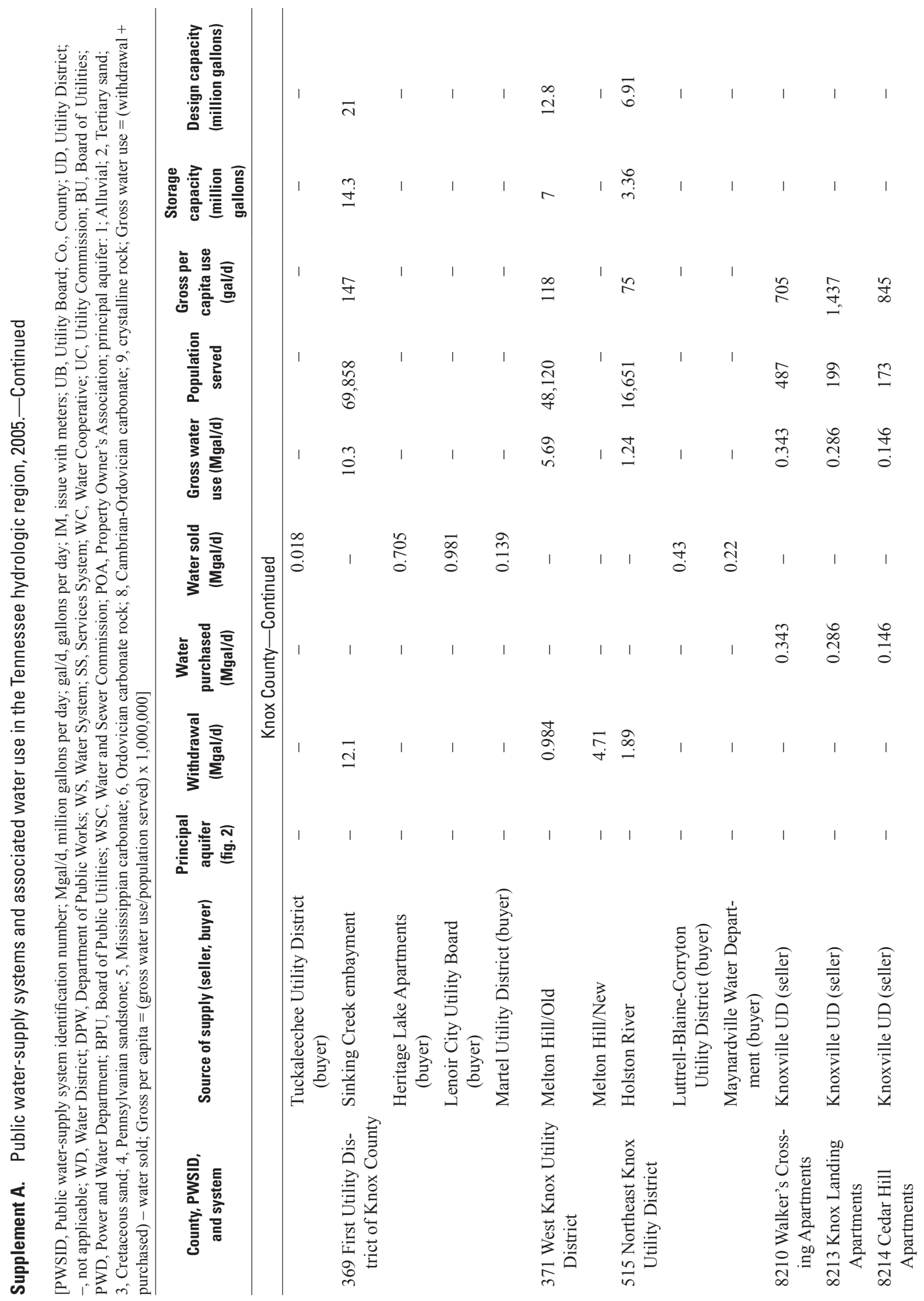




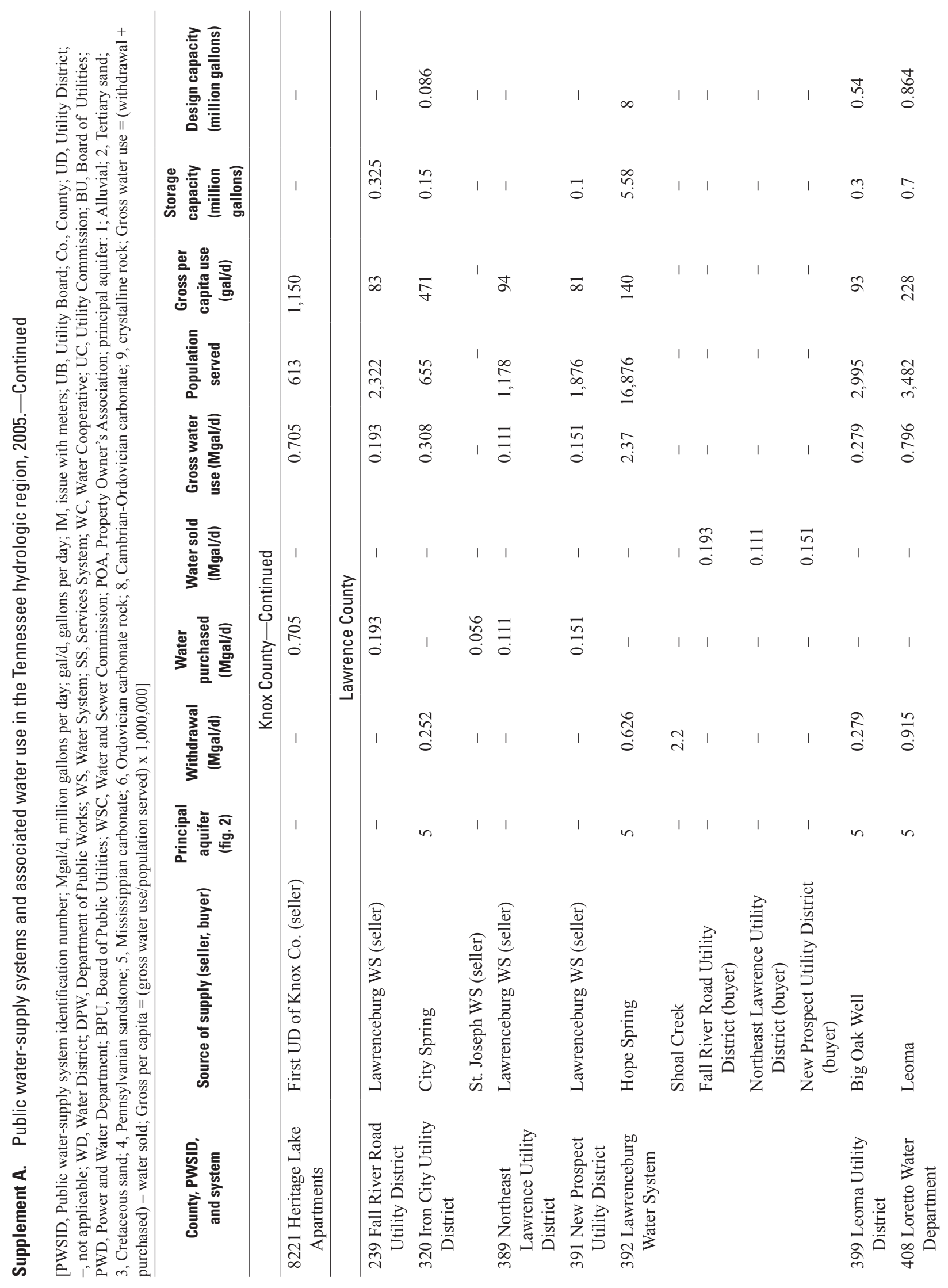




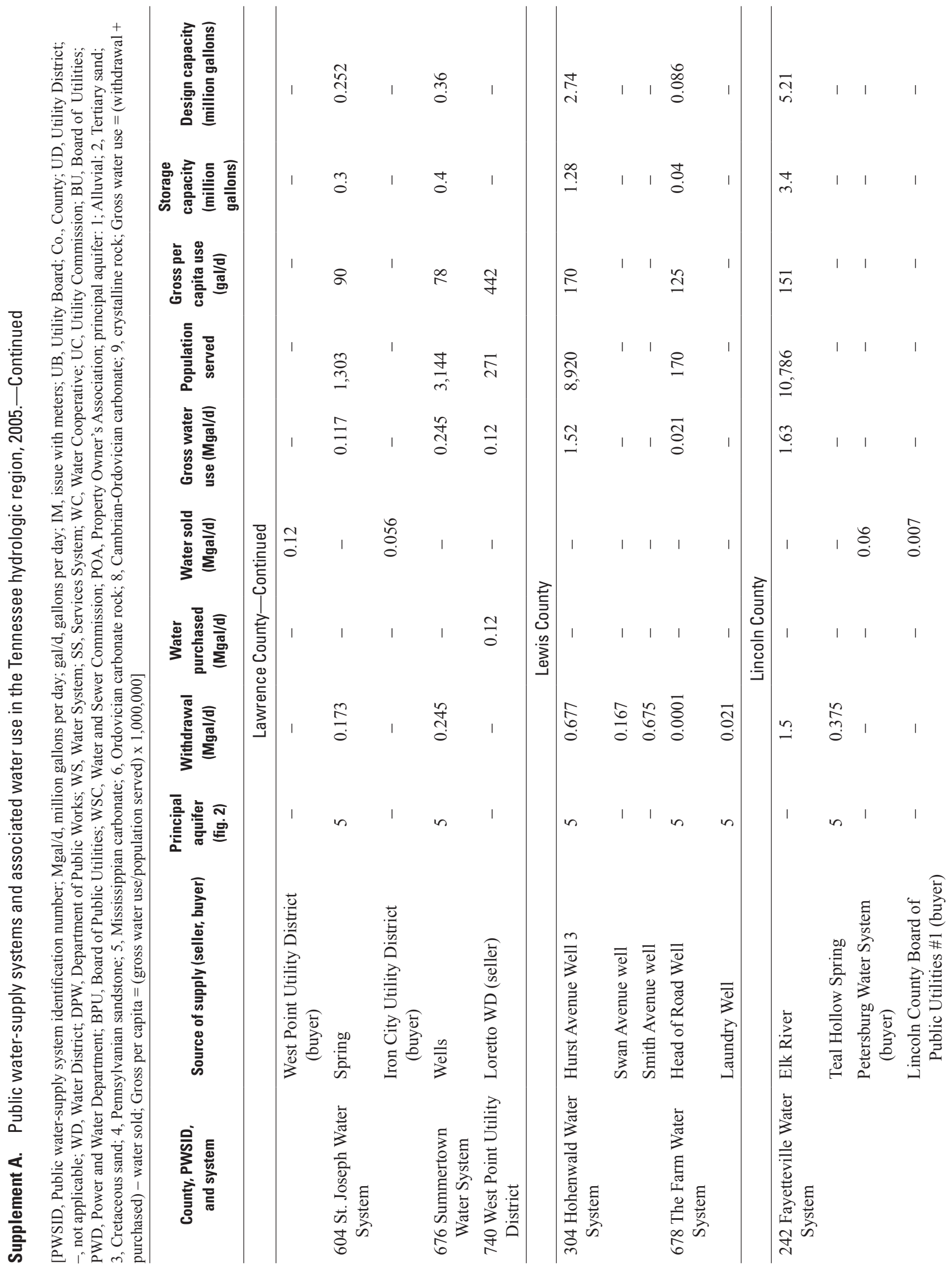




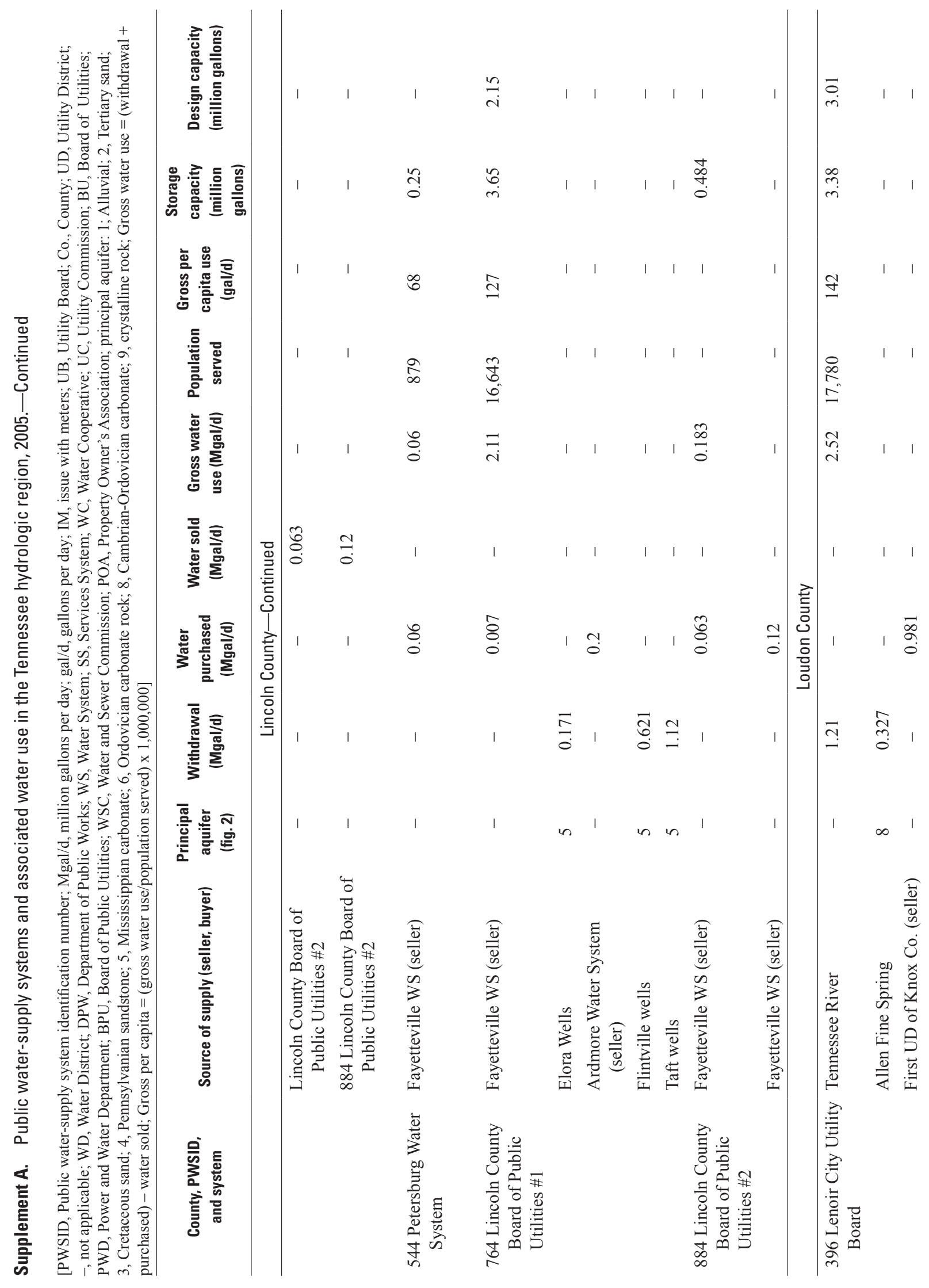




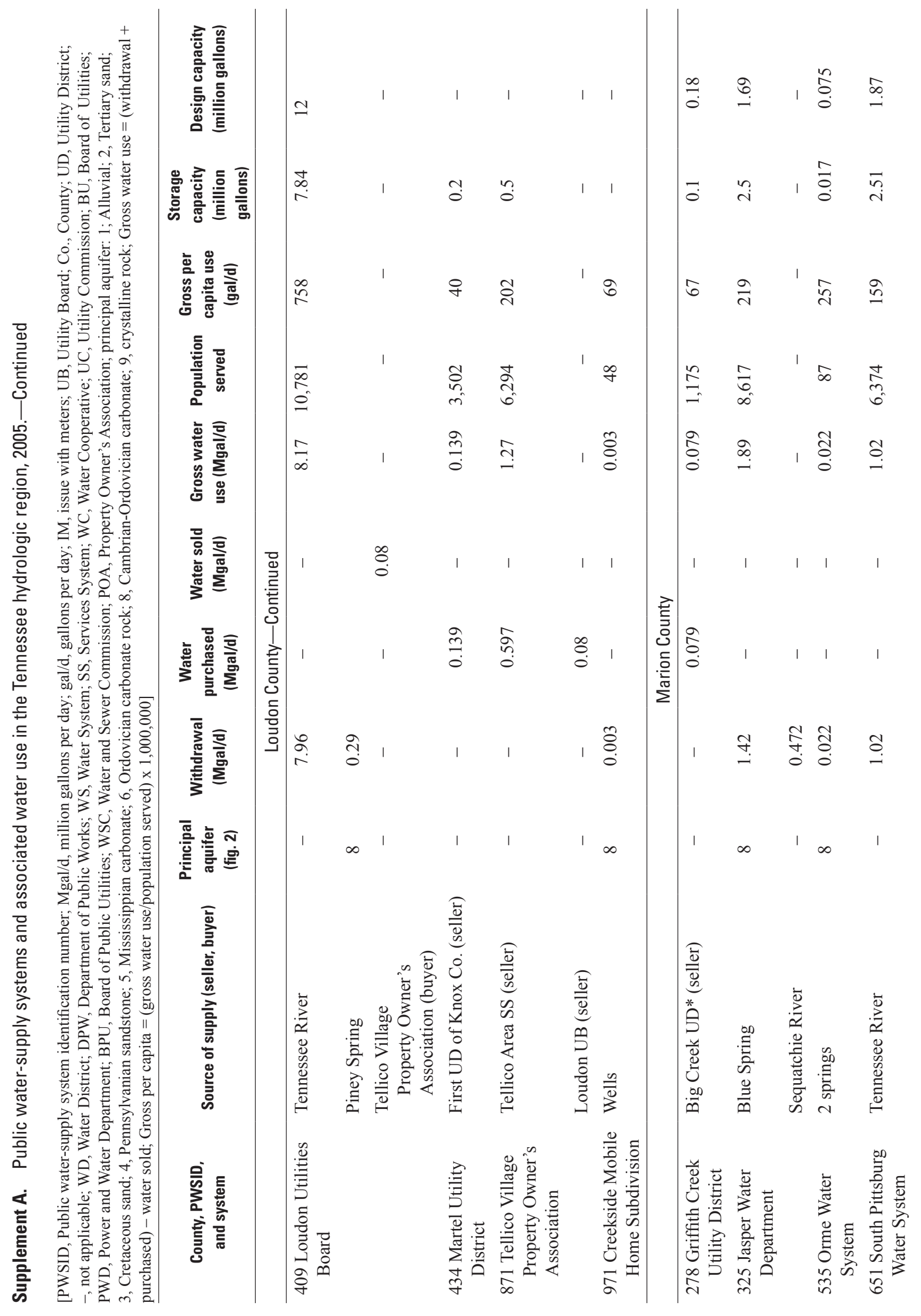




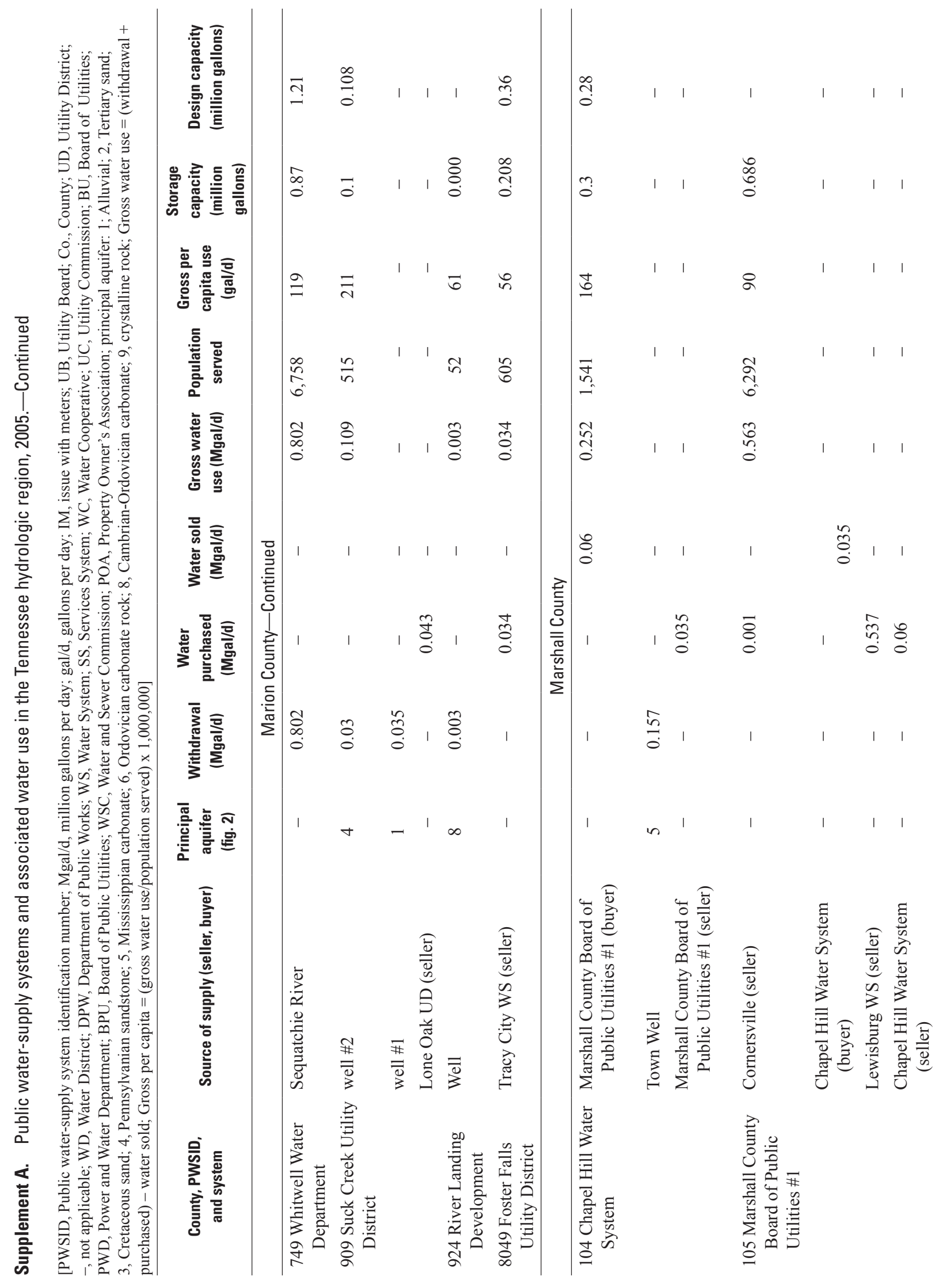




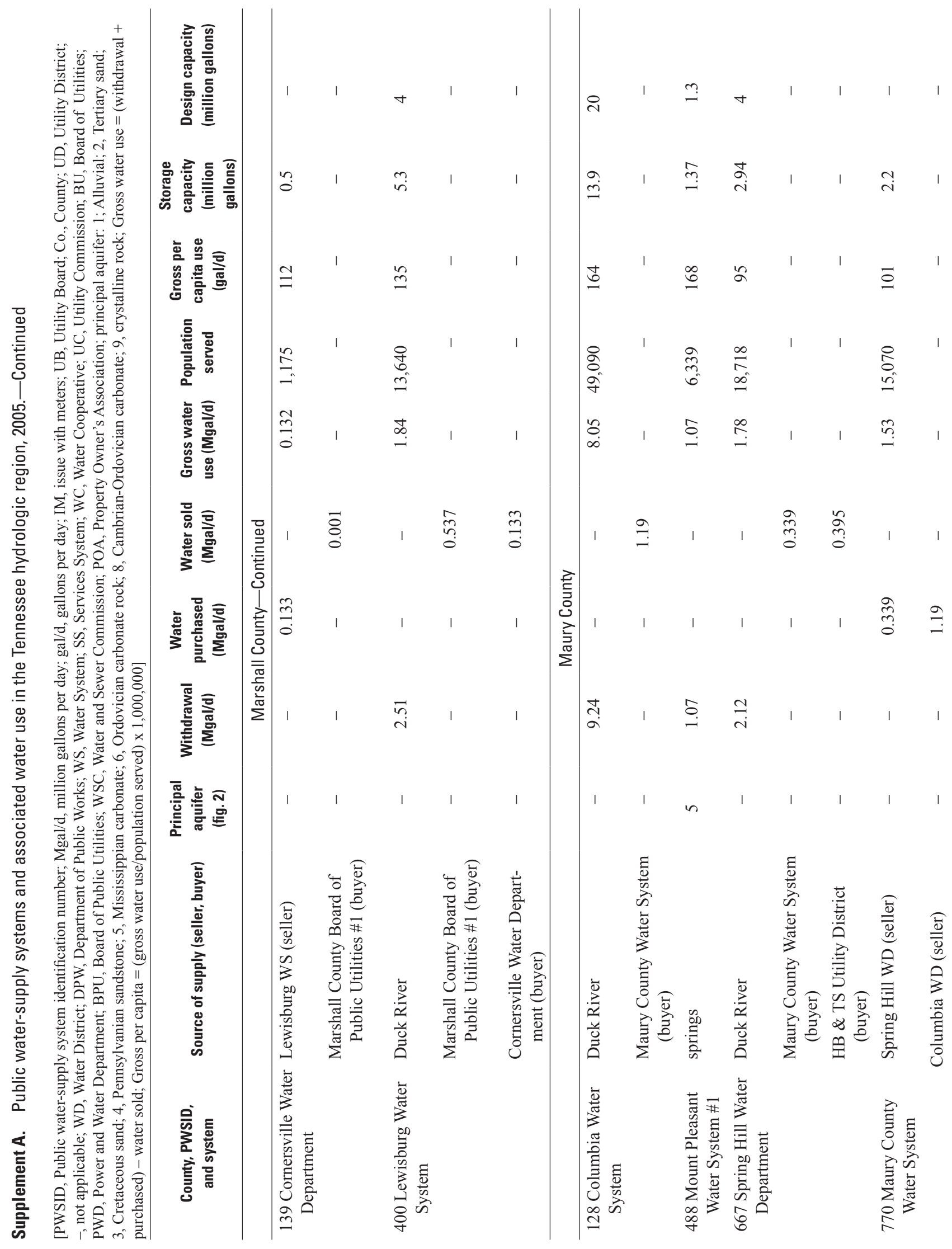




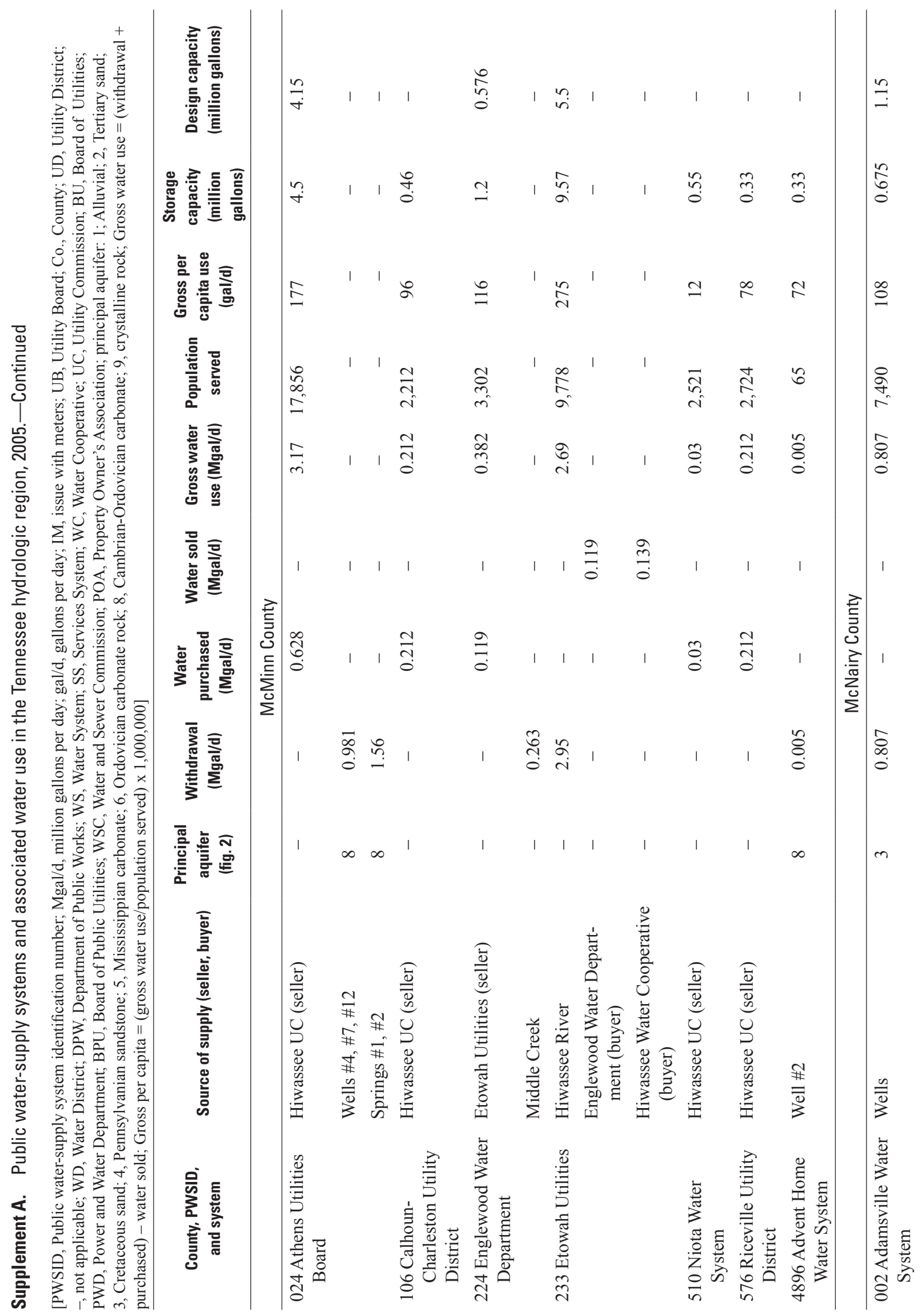




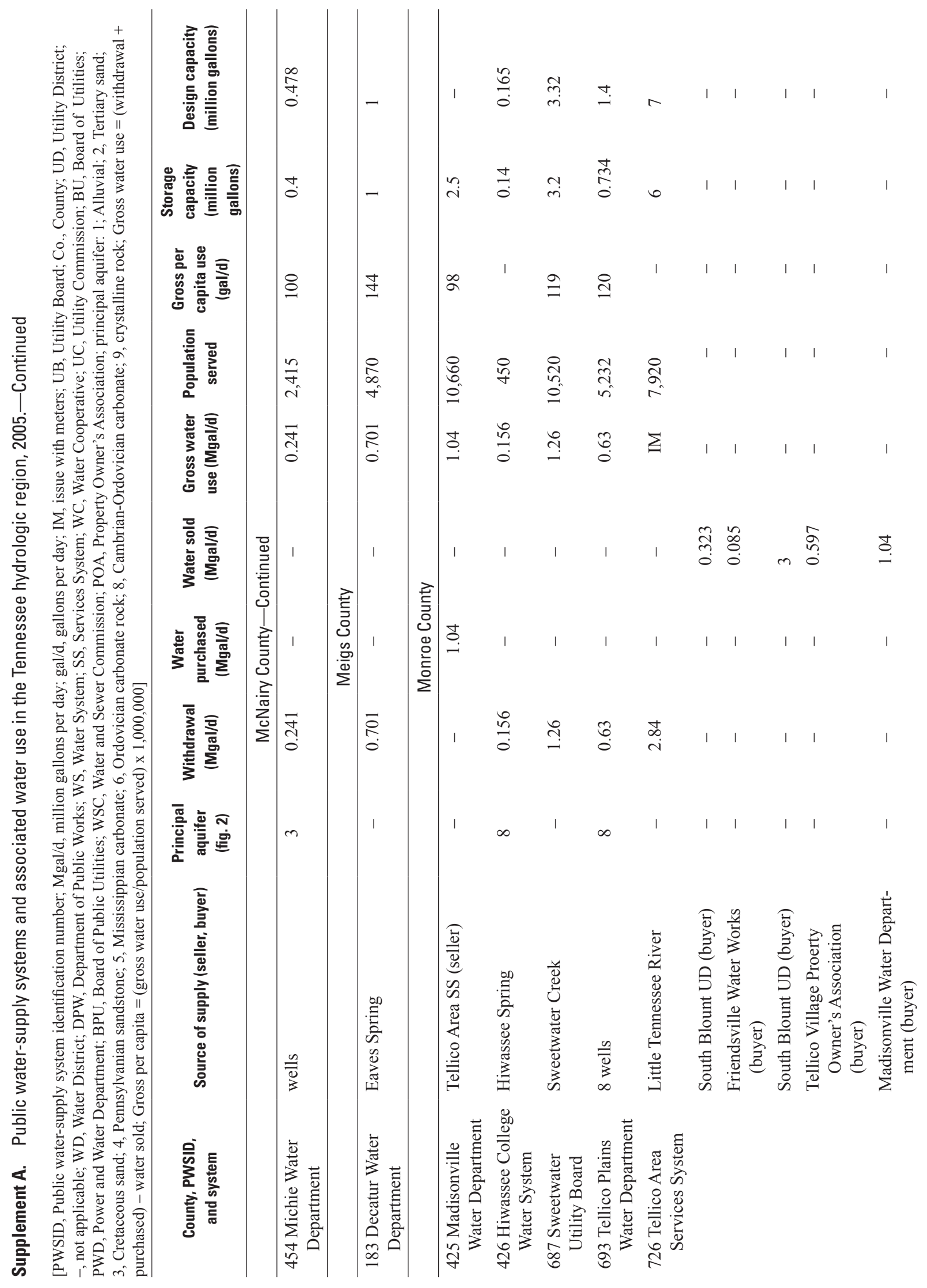




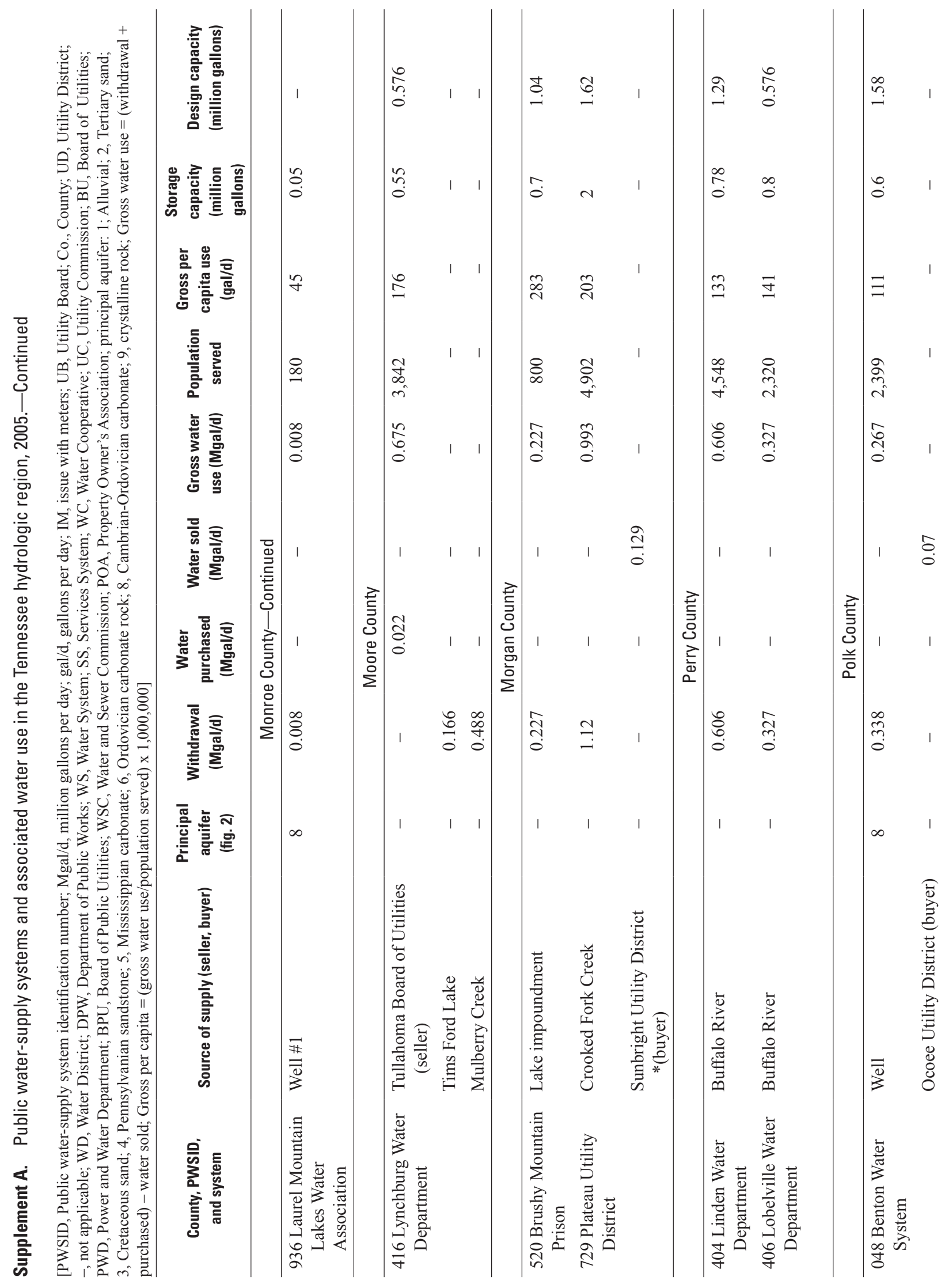




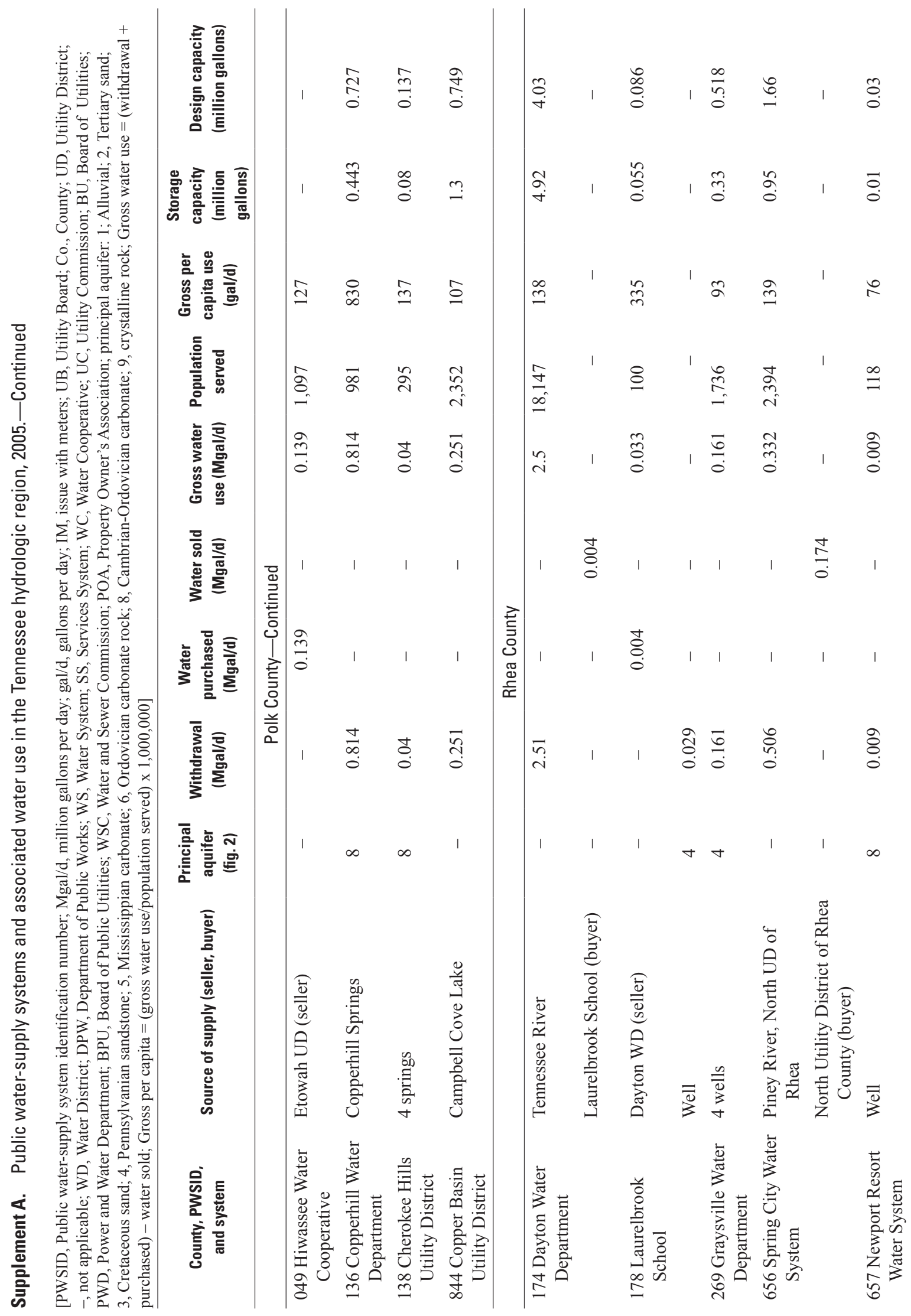




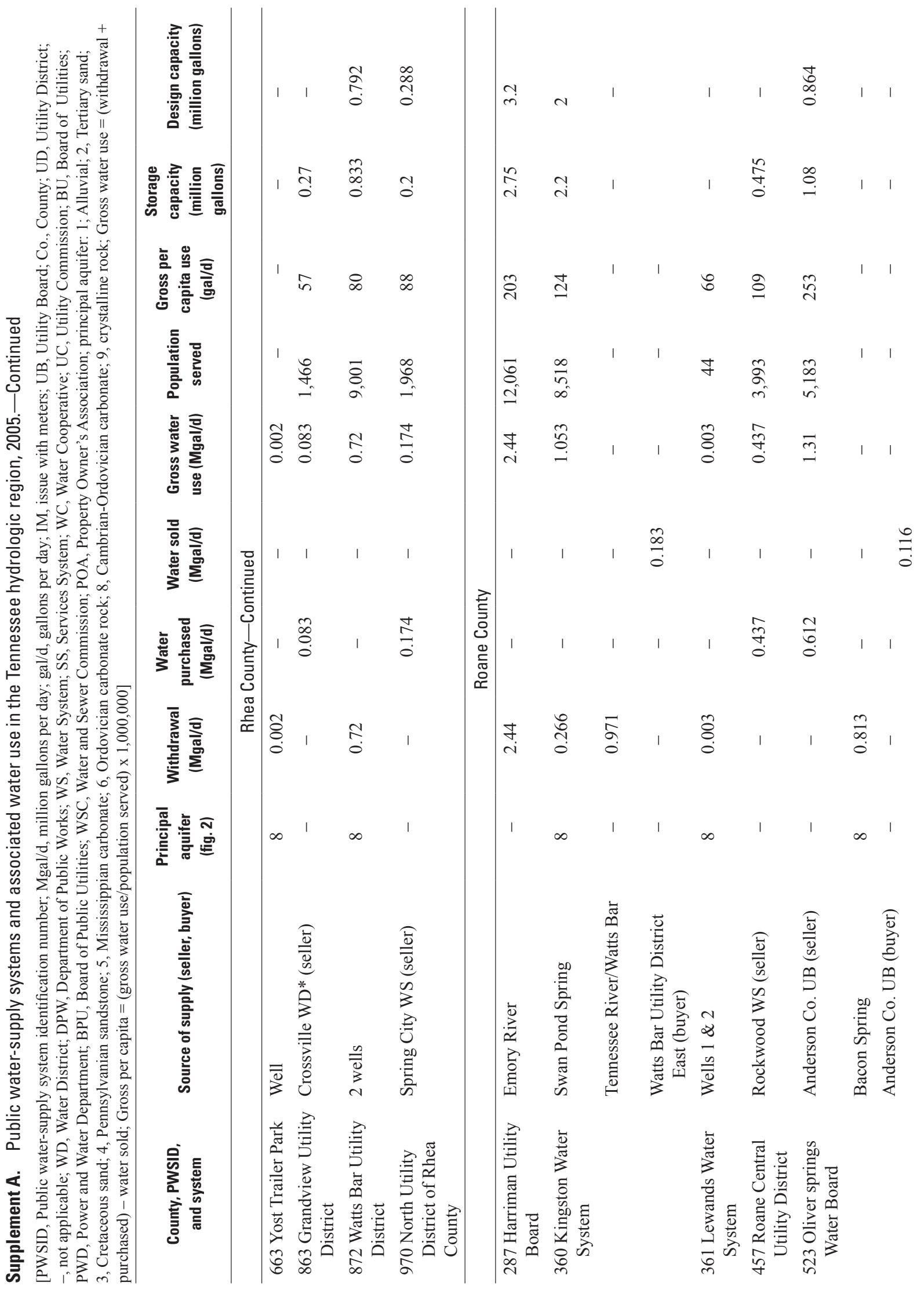




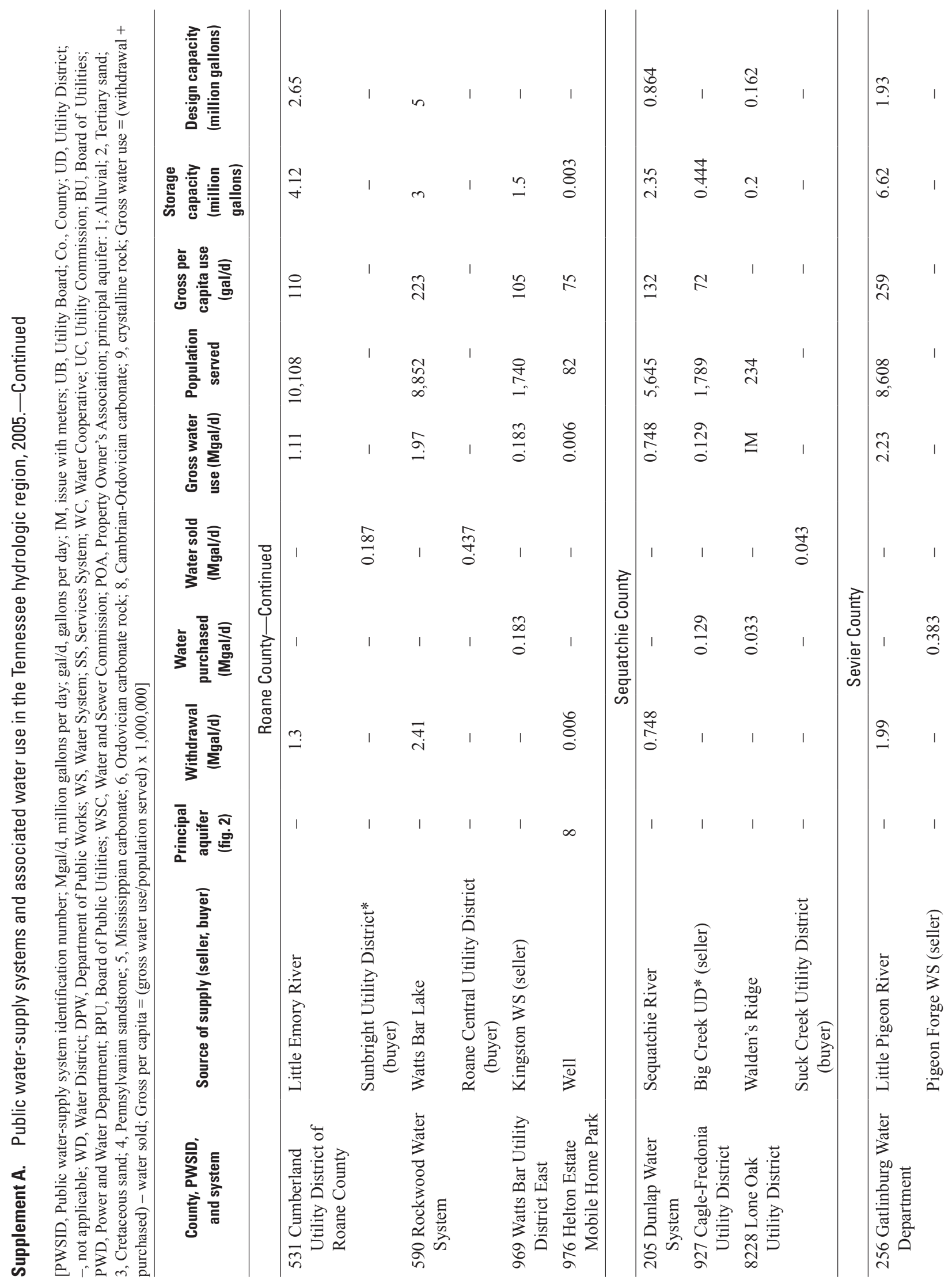




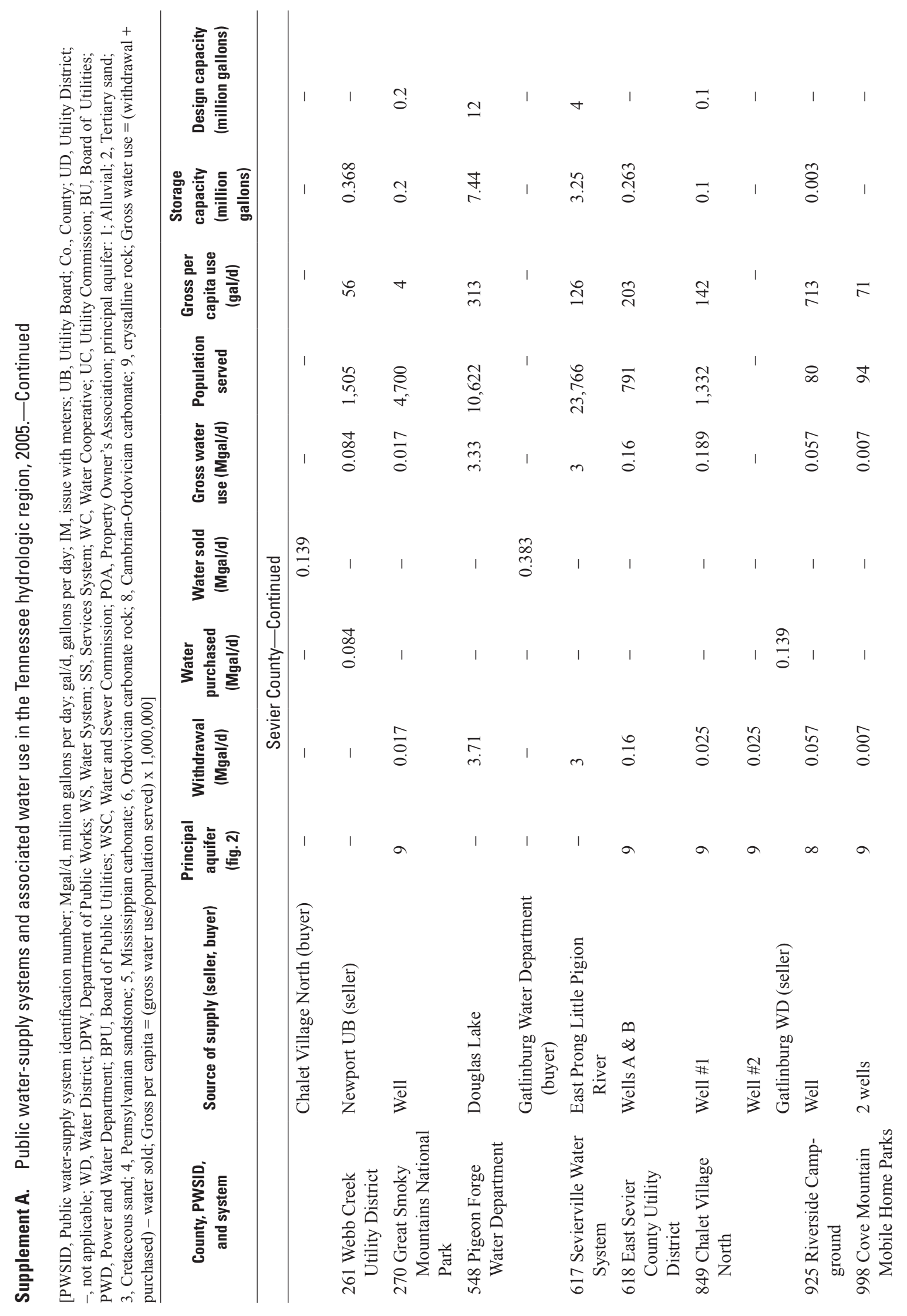




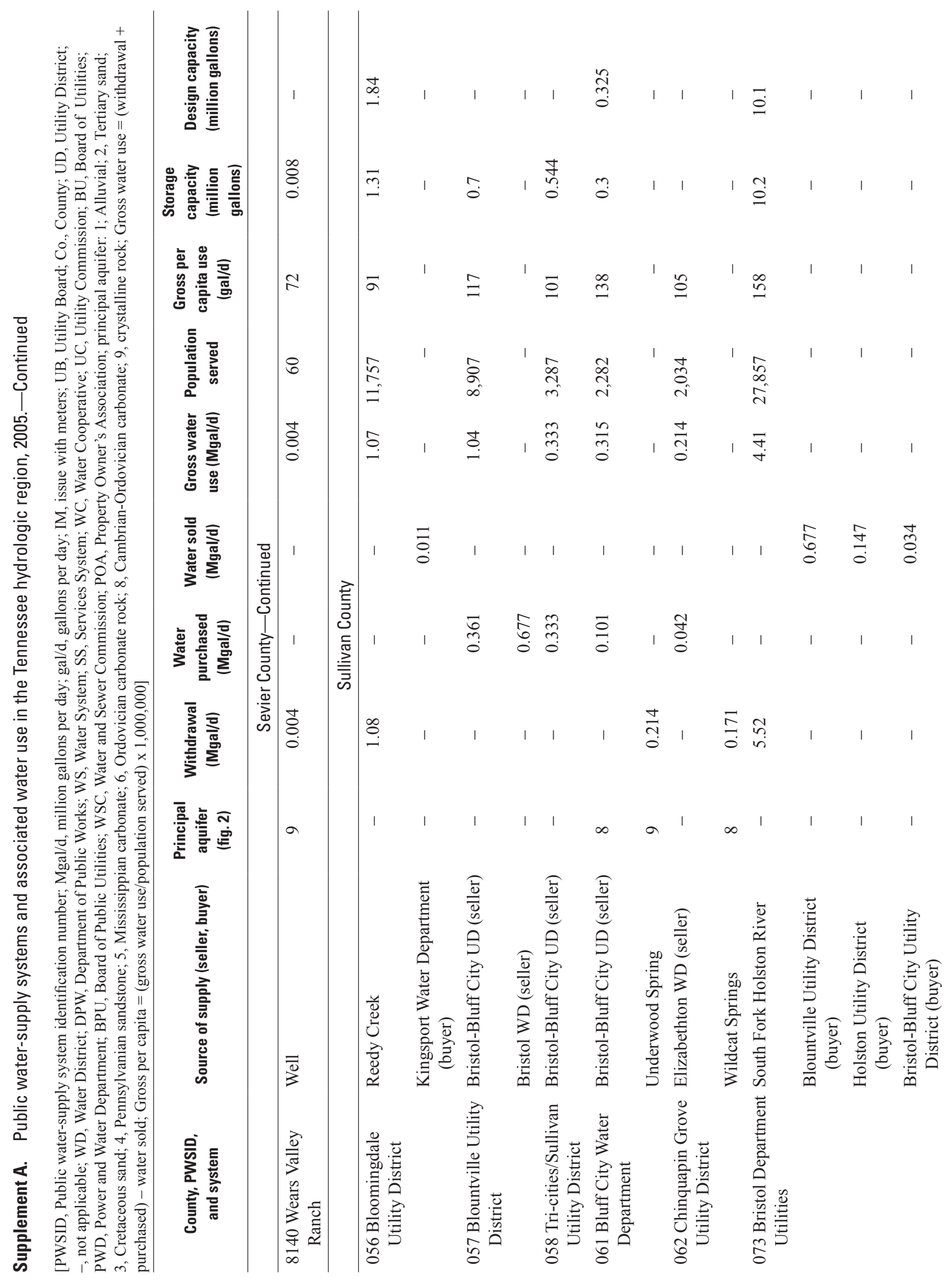




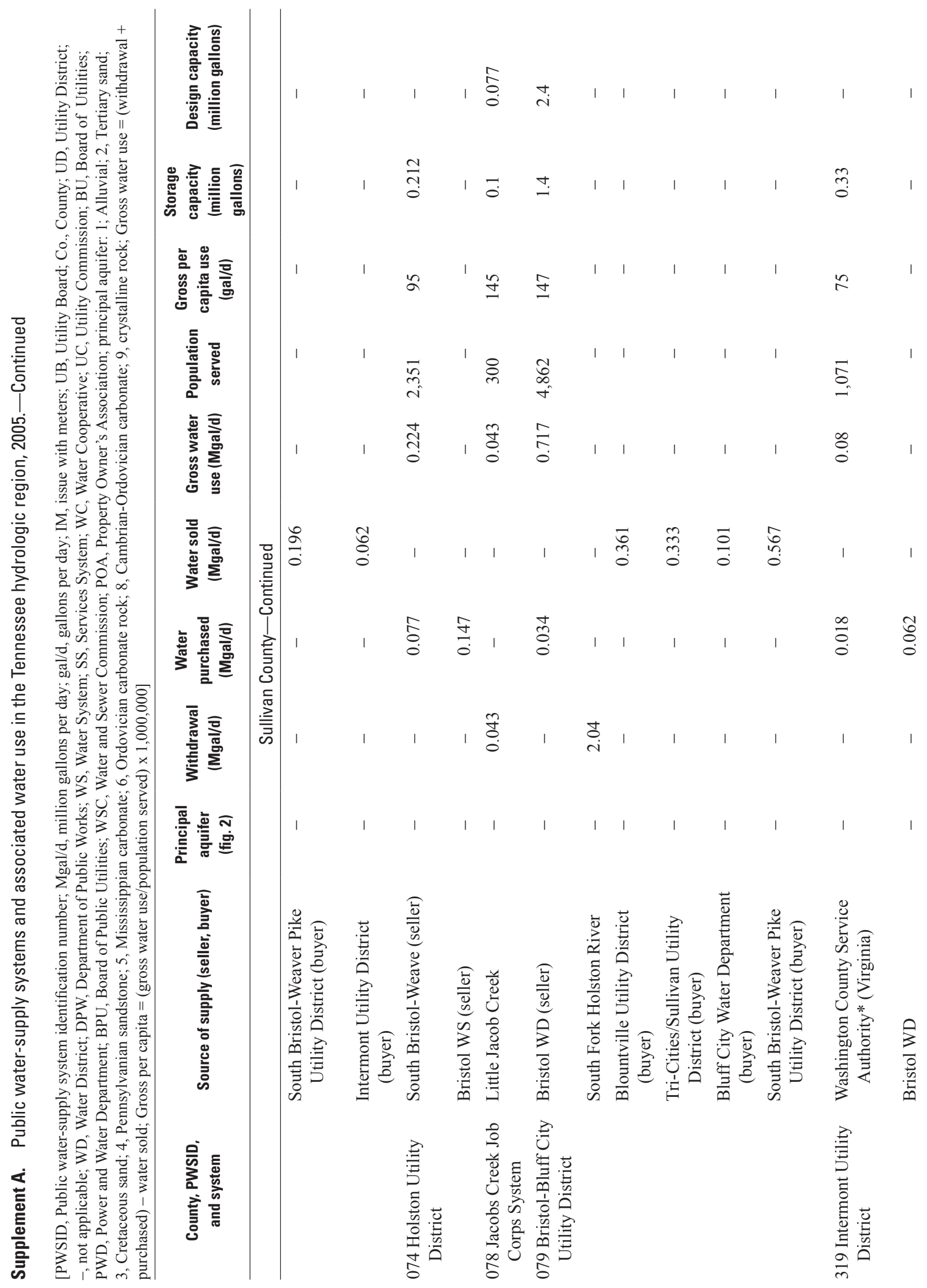




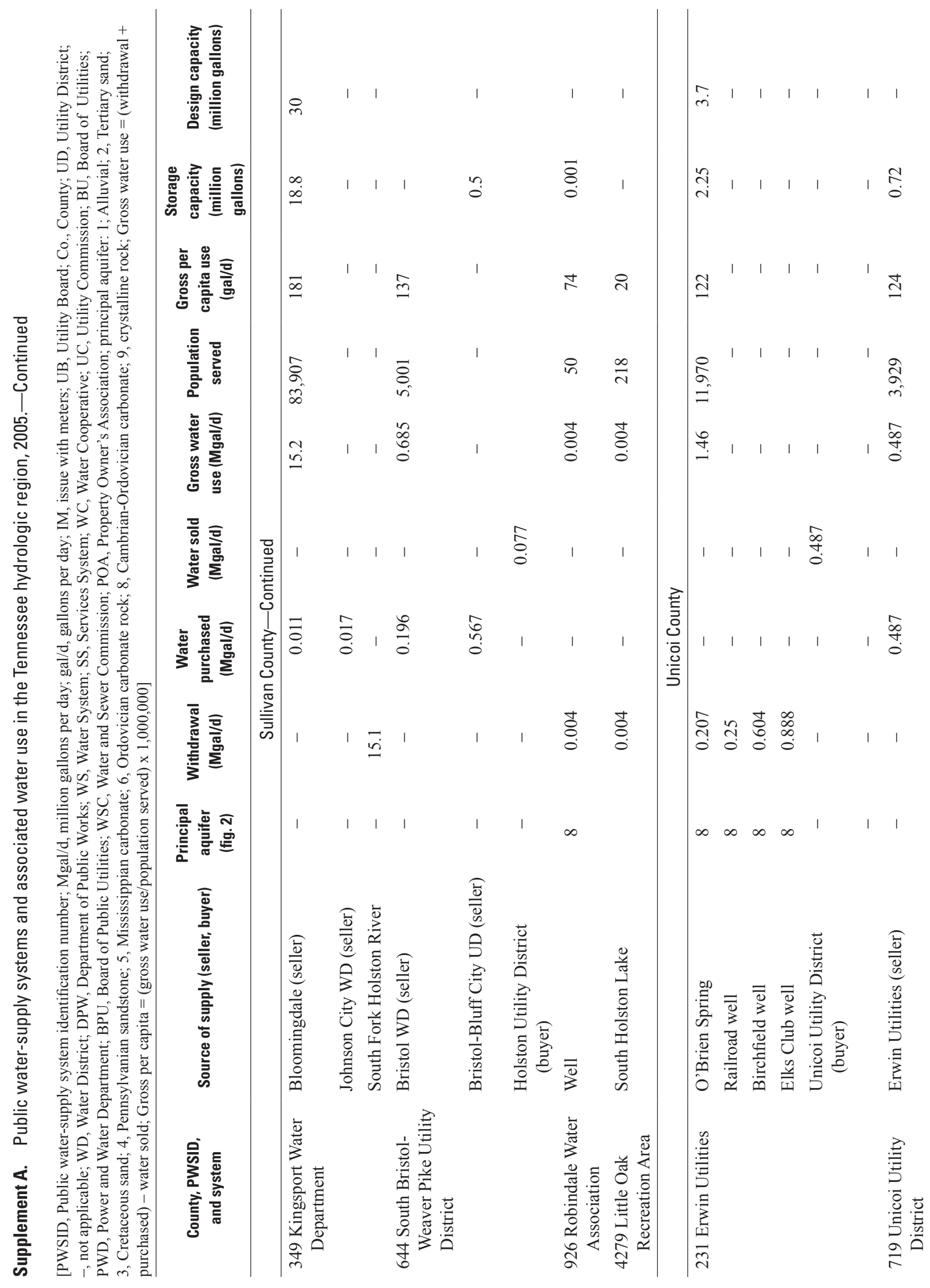




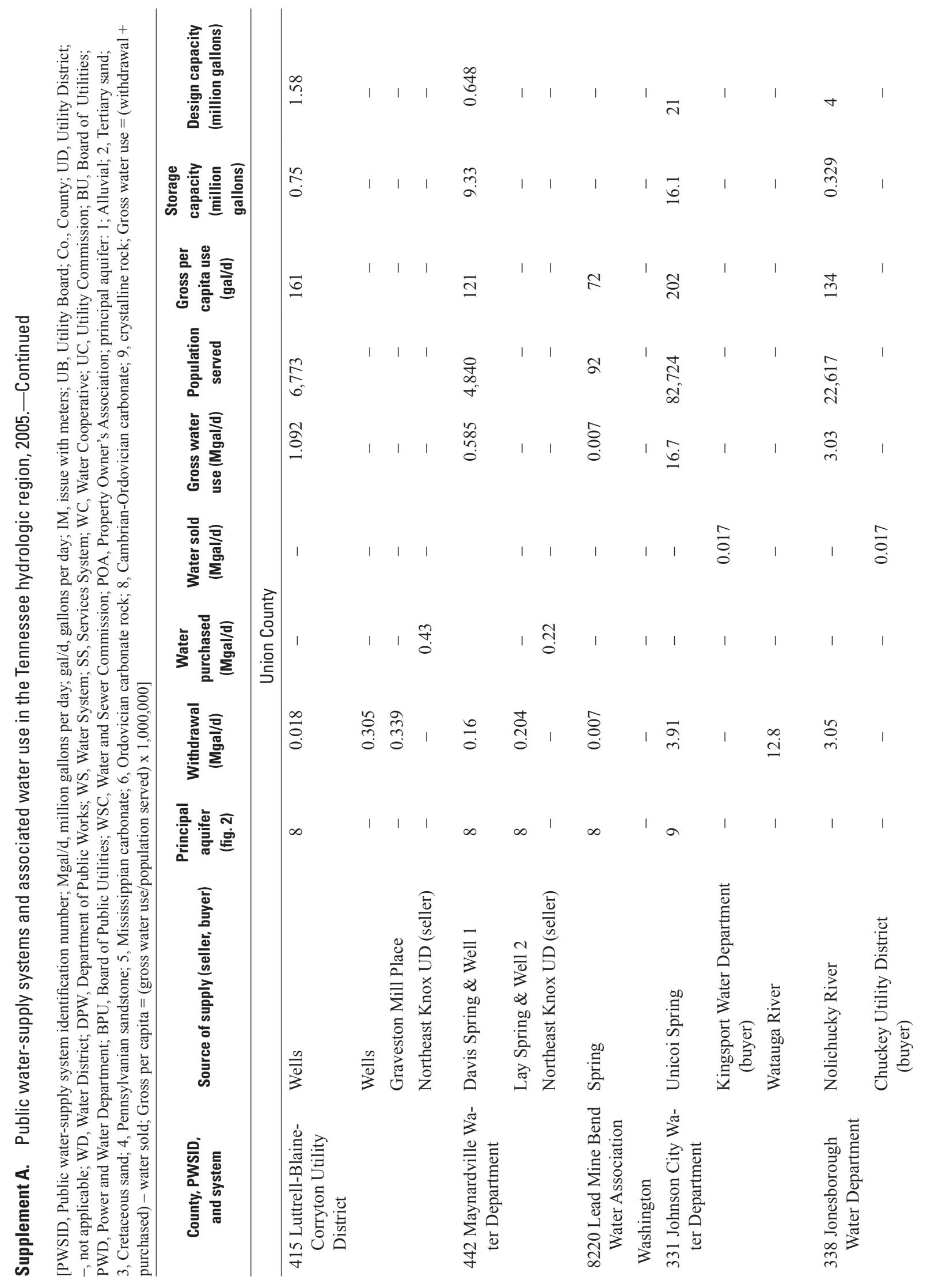




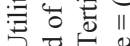

Sิ

家部

के

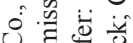

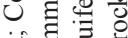

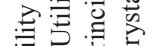

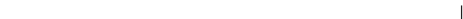

홍

总莺总 兽

高 象 $\begin{array}{lll}0 & n \\ \vdots & 0 \\ 0 & 0\end{array}$

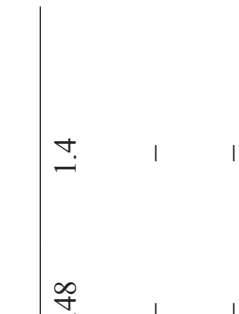

岁芯

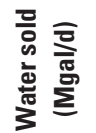

票 $\overline{\mathrm{a}}$

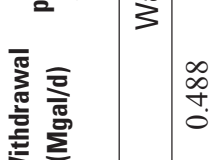

$\stackrel{\substack{\infty \\ \infty}}{0}$

ฮั ส

产富兽

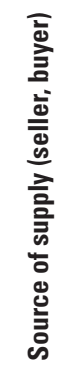

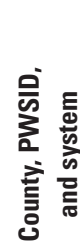
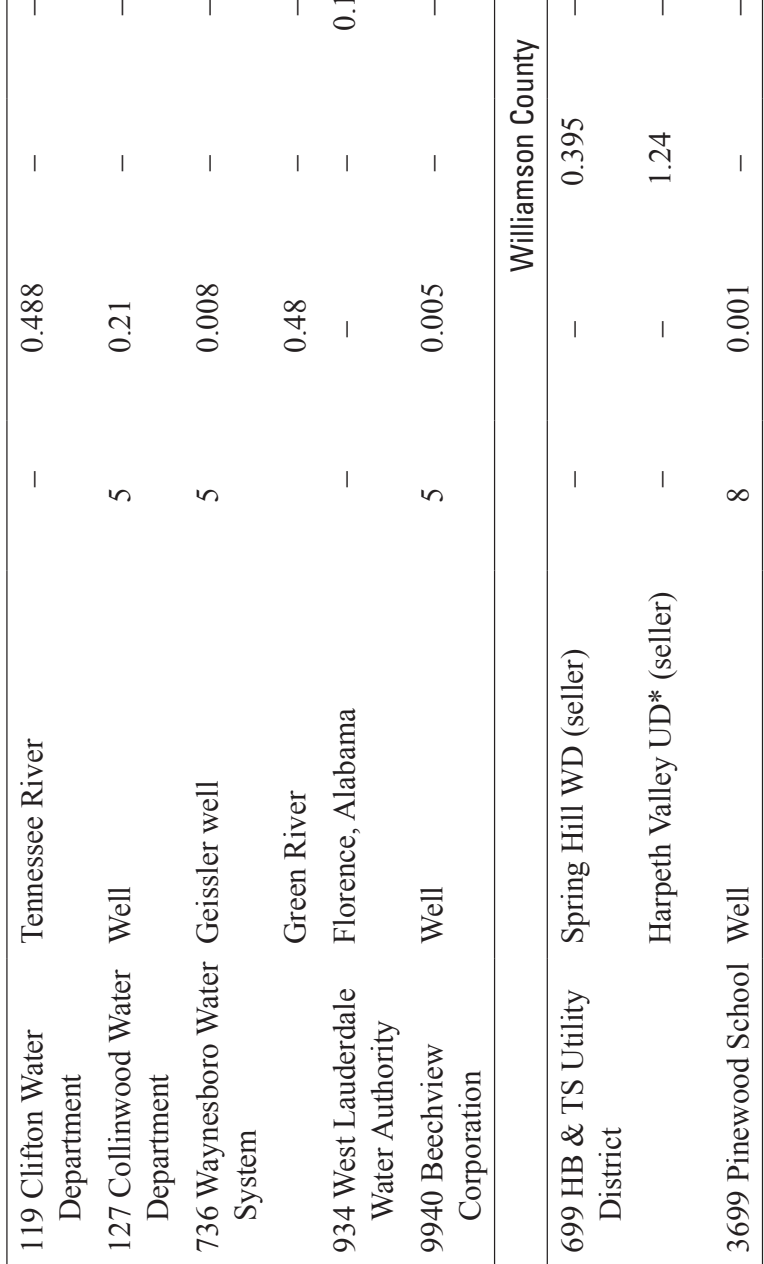

Suppliment B-Public water-supply systems and associated water use in the Ohio hydrologic region 


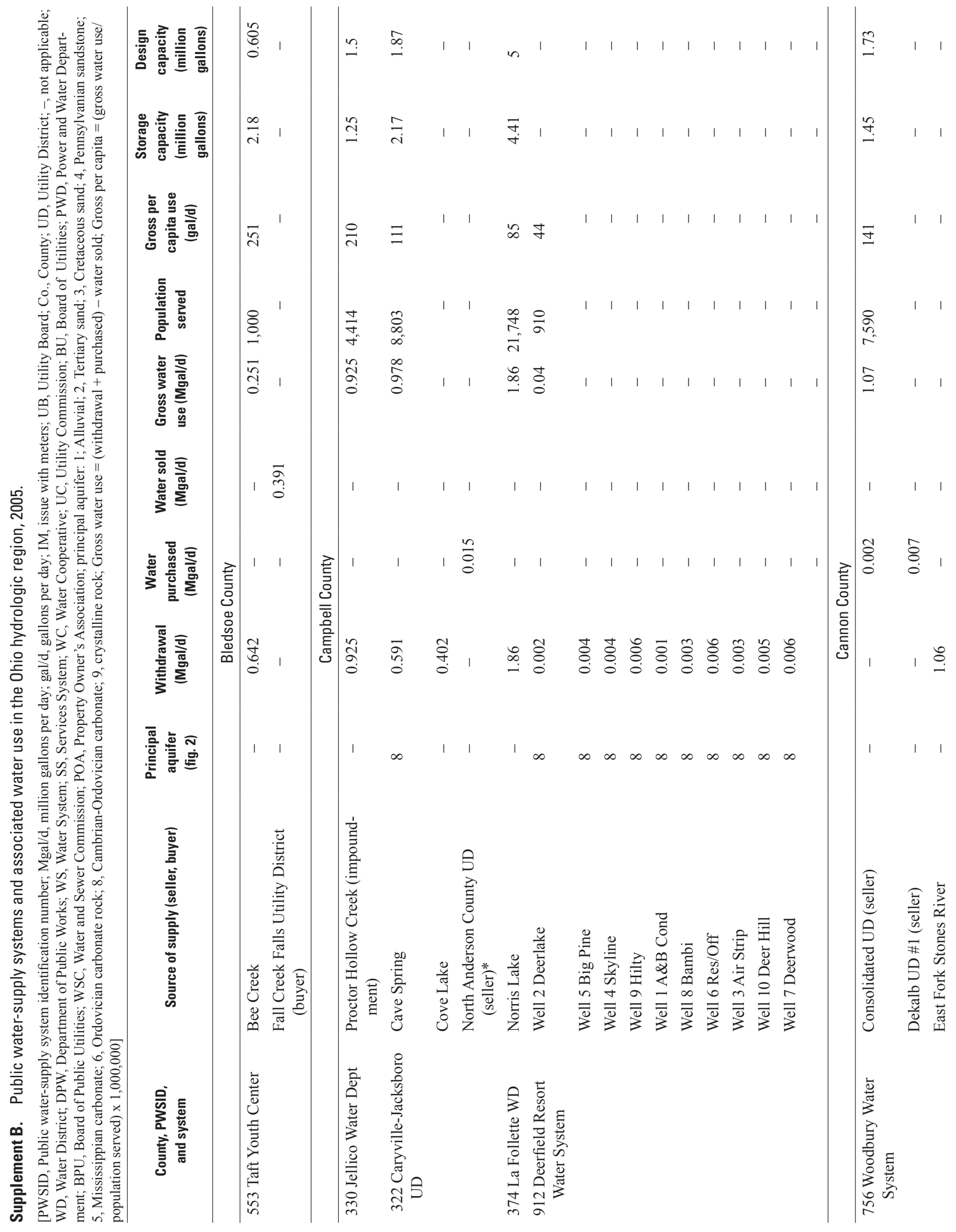




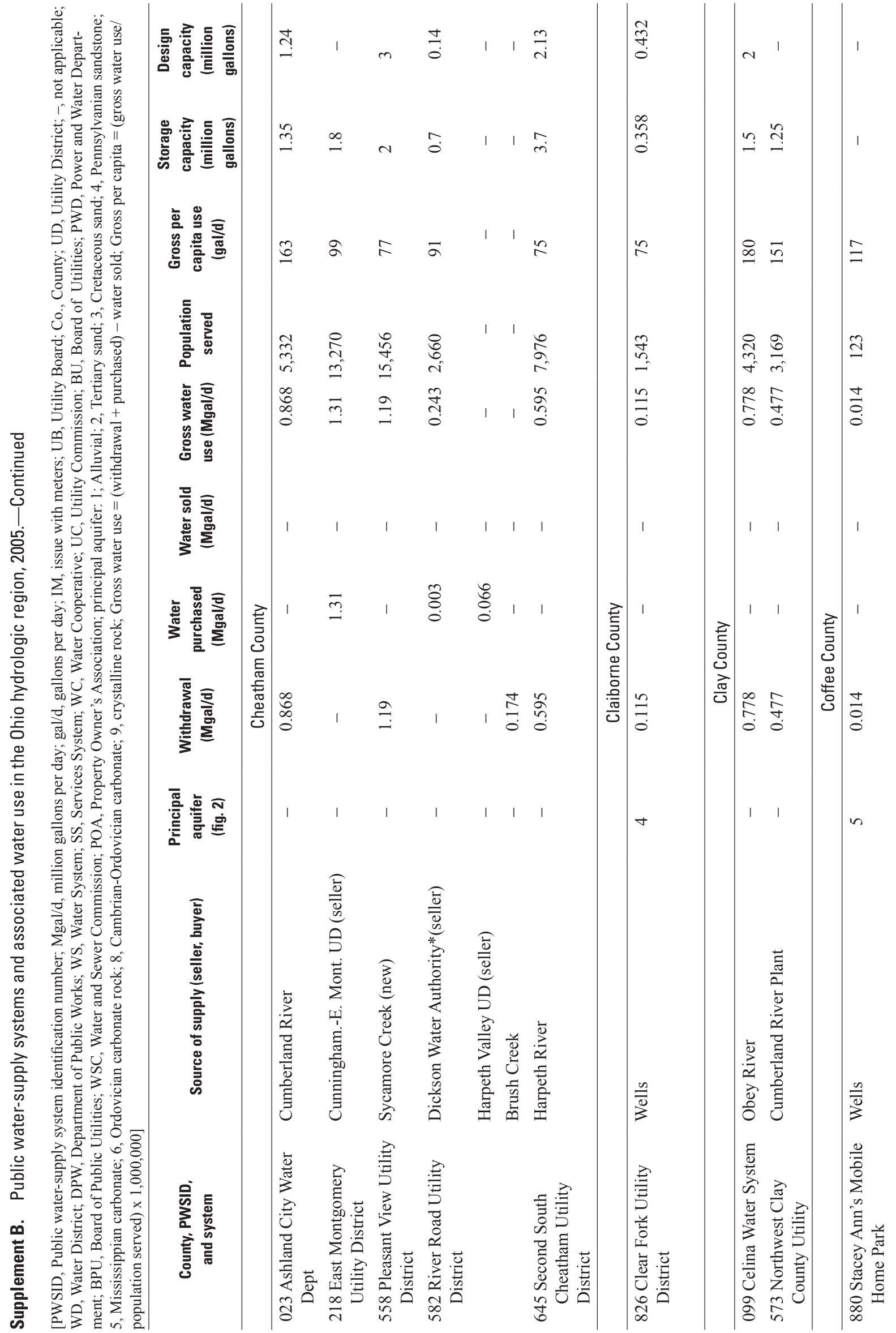




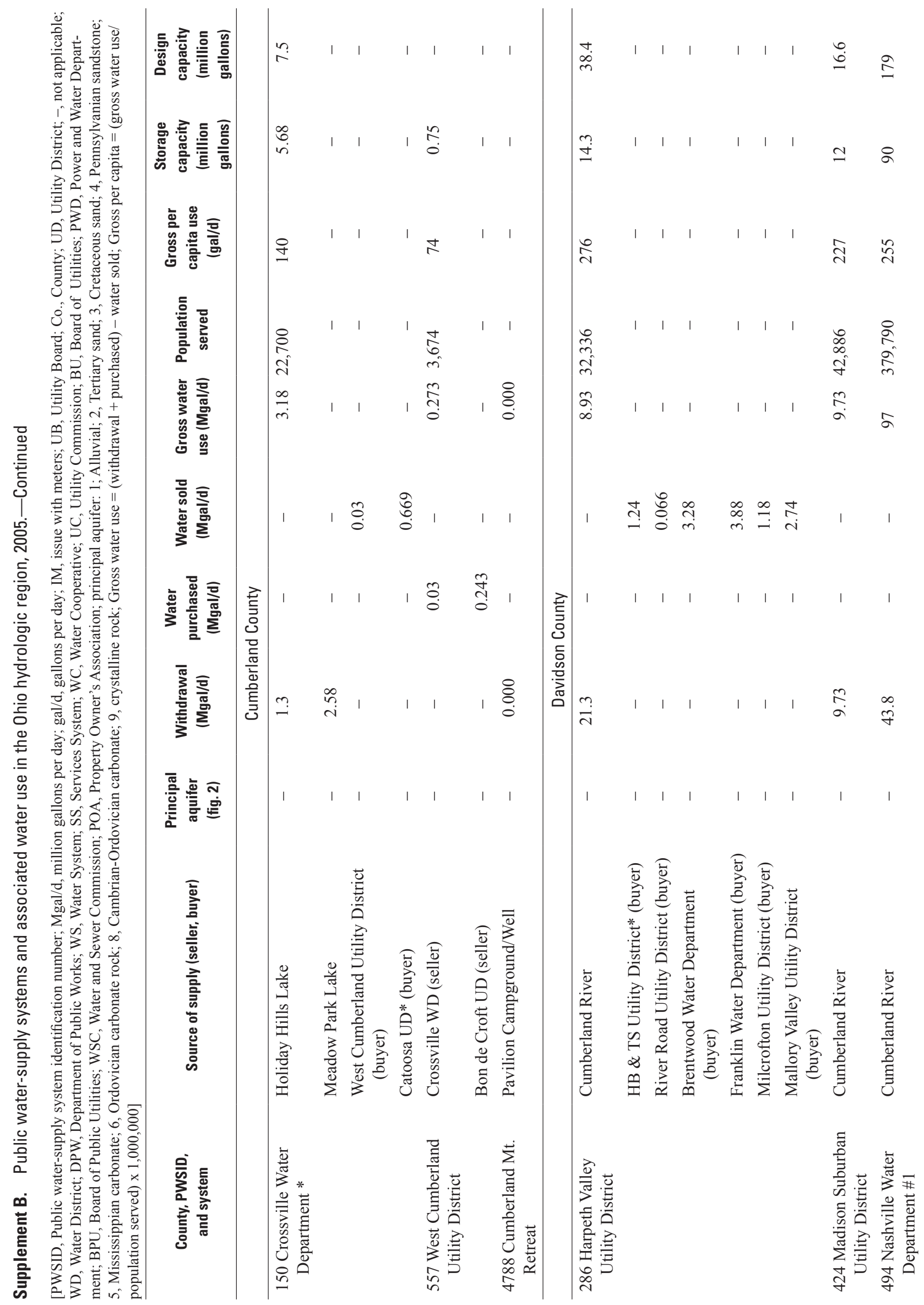




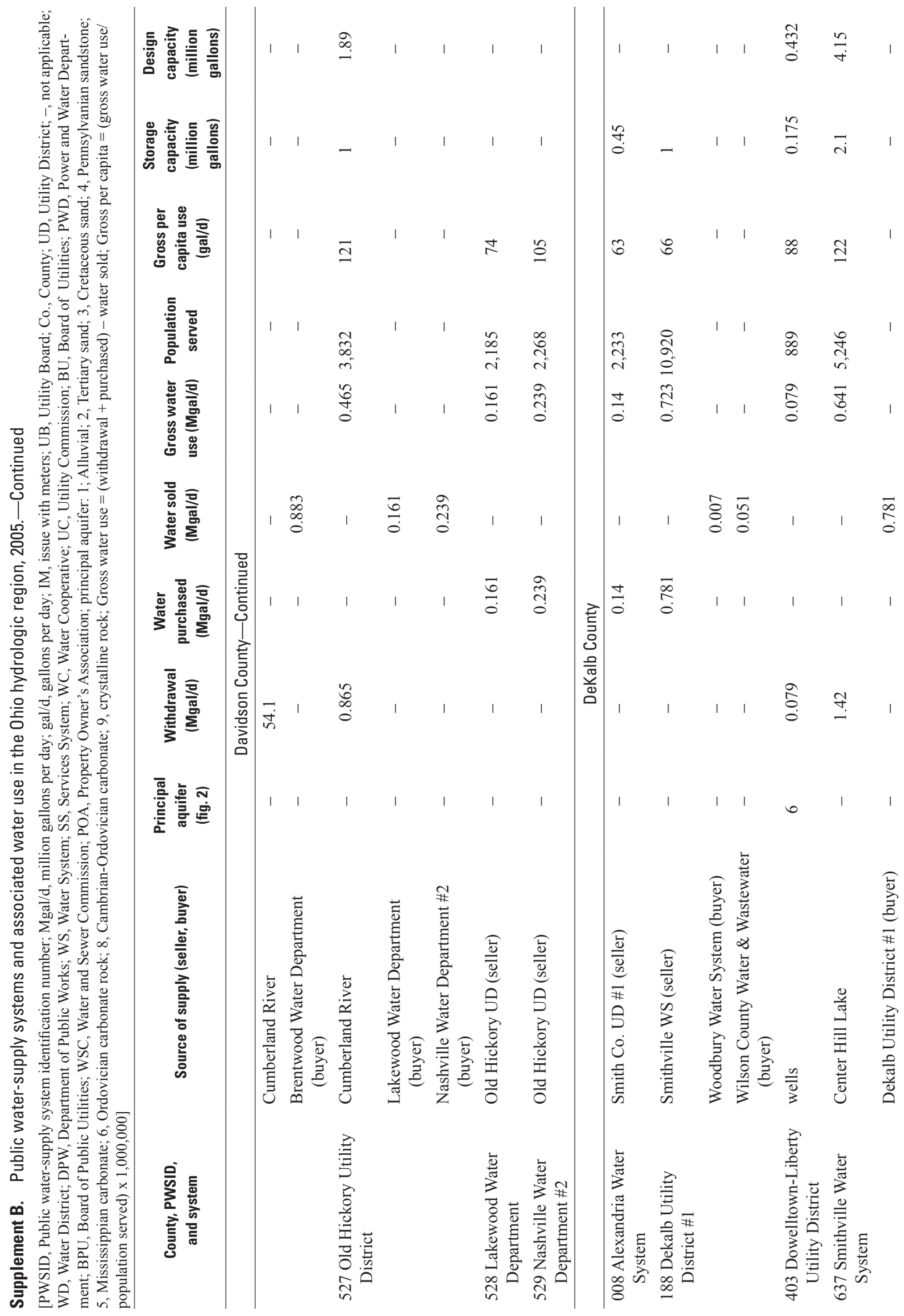




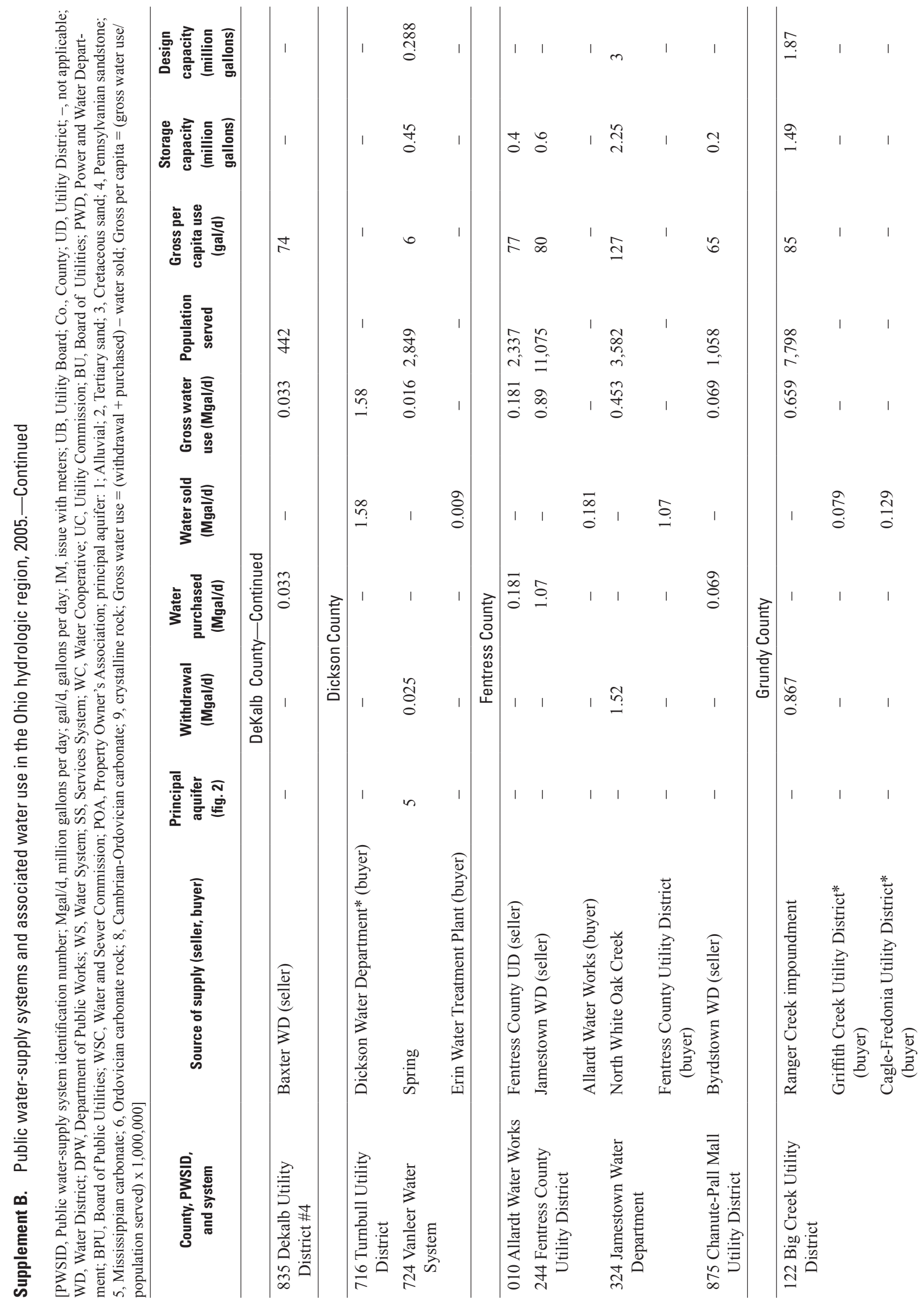




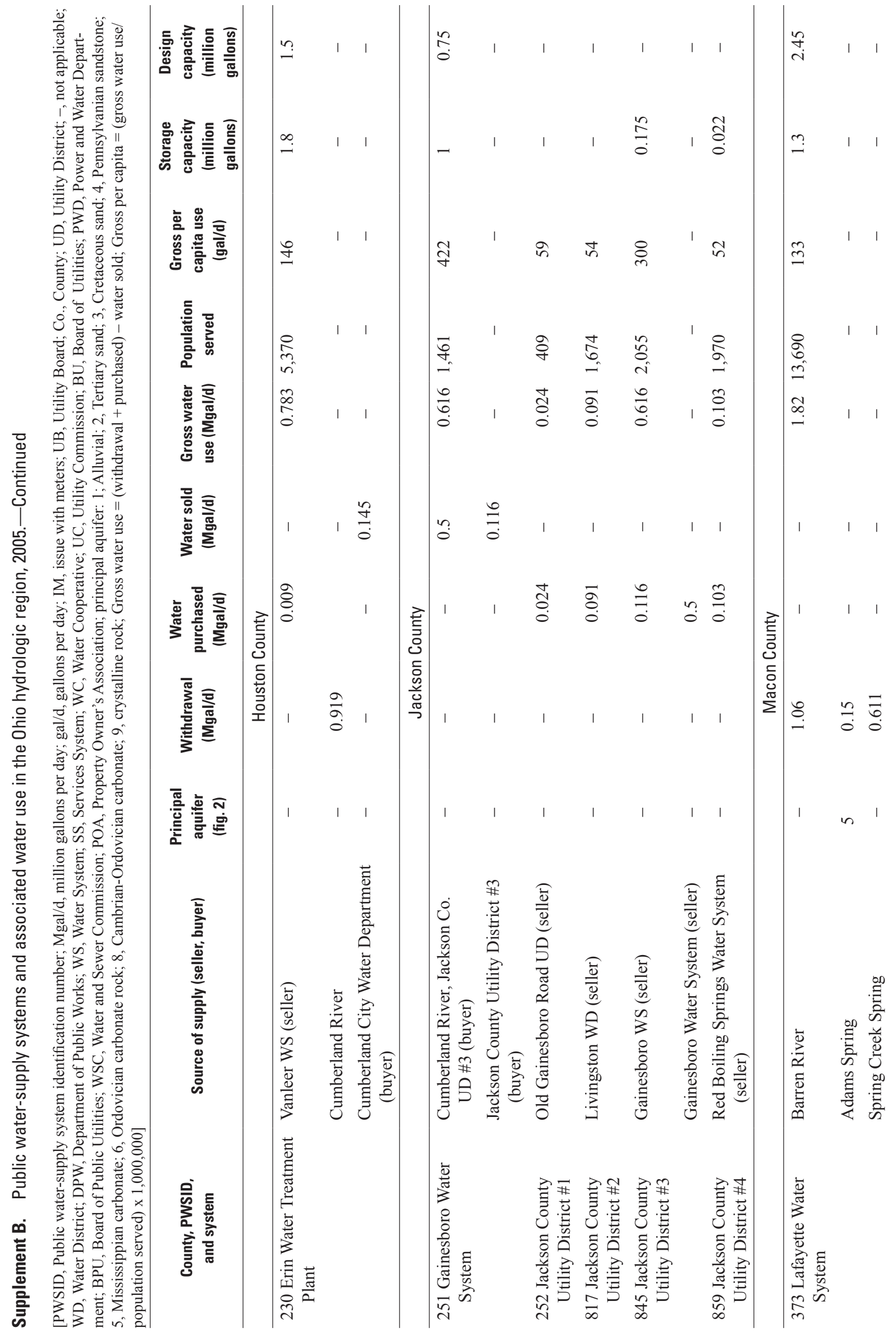




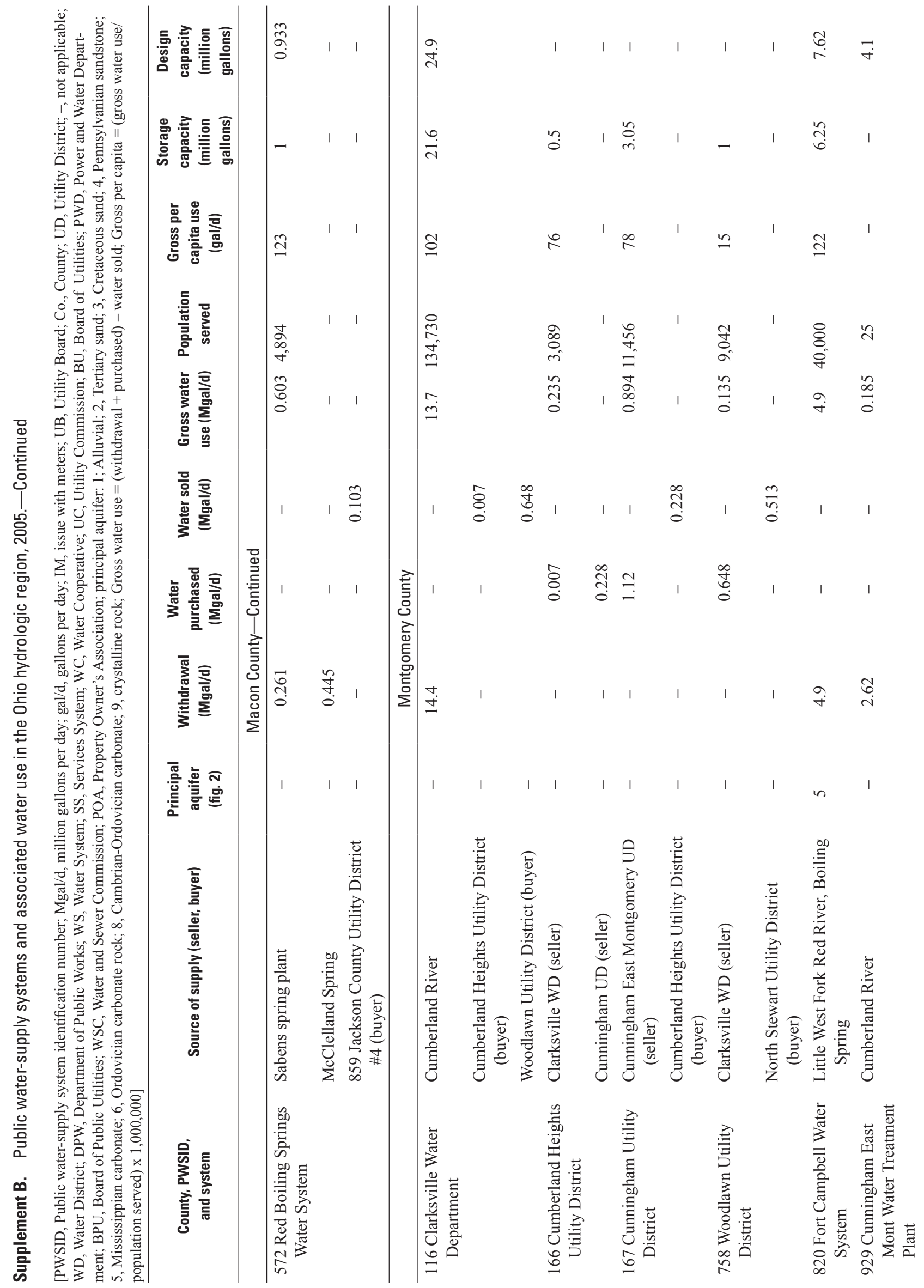




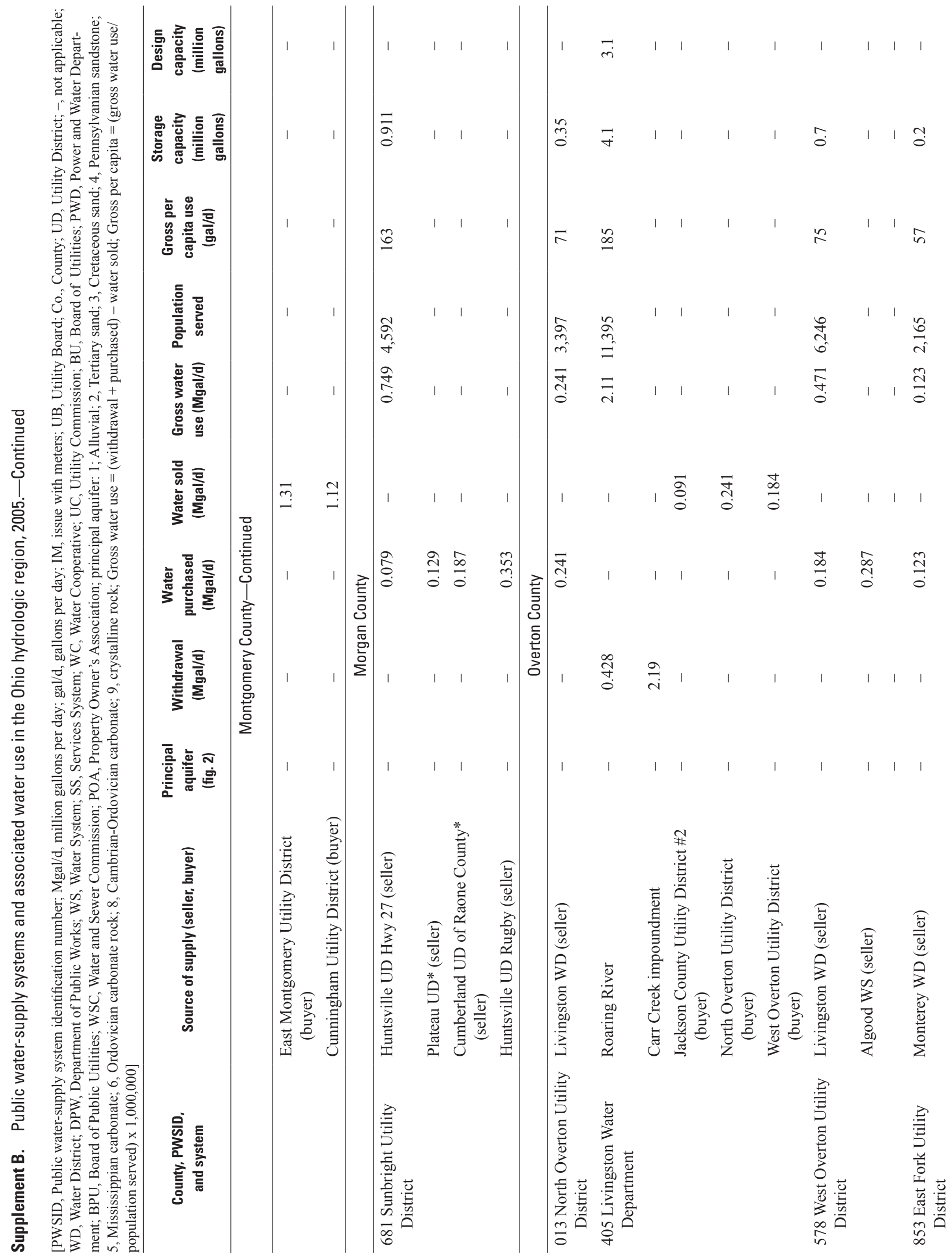




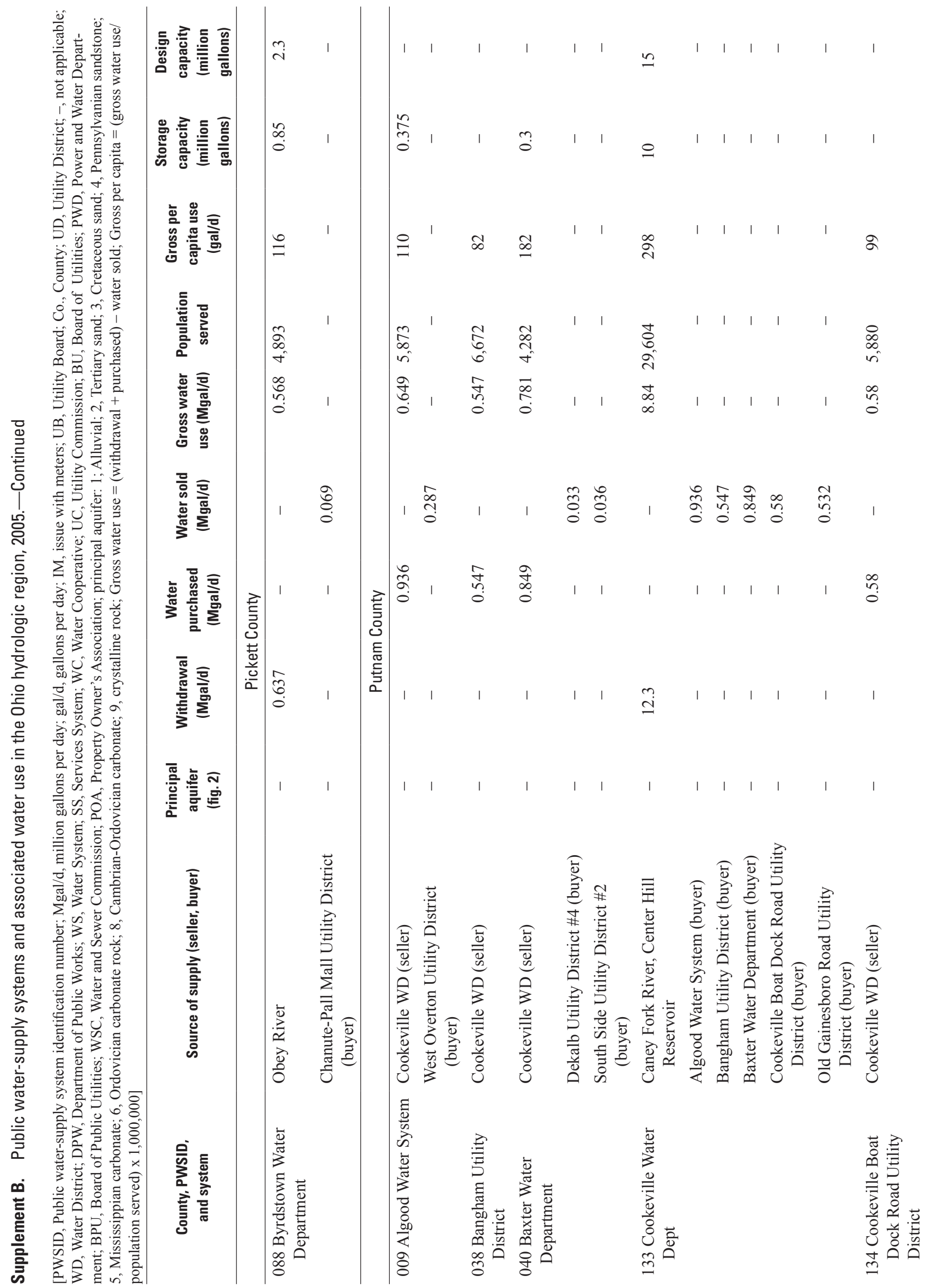




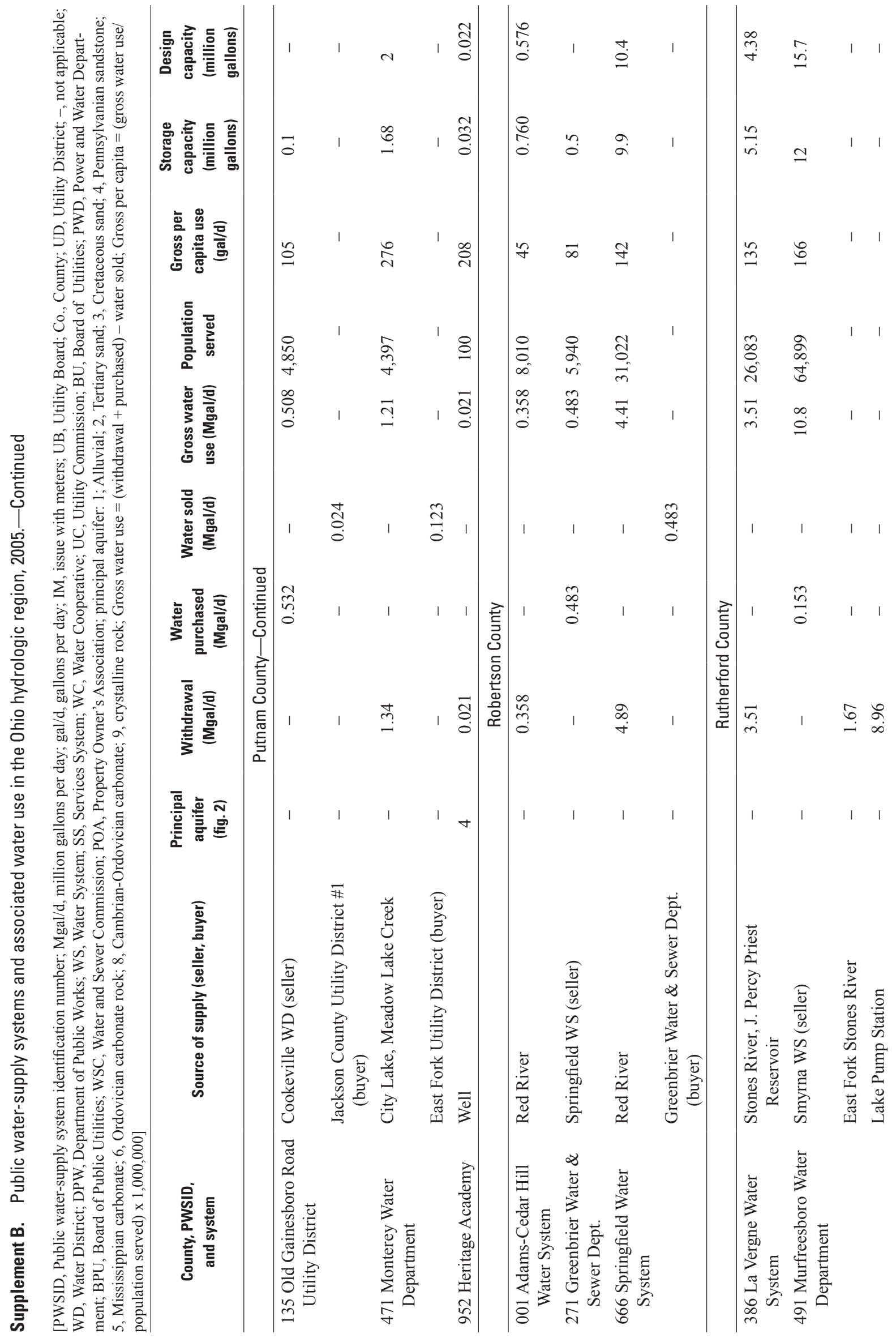




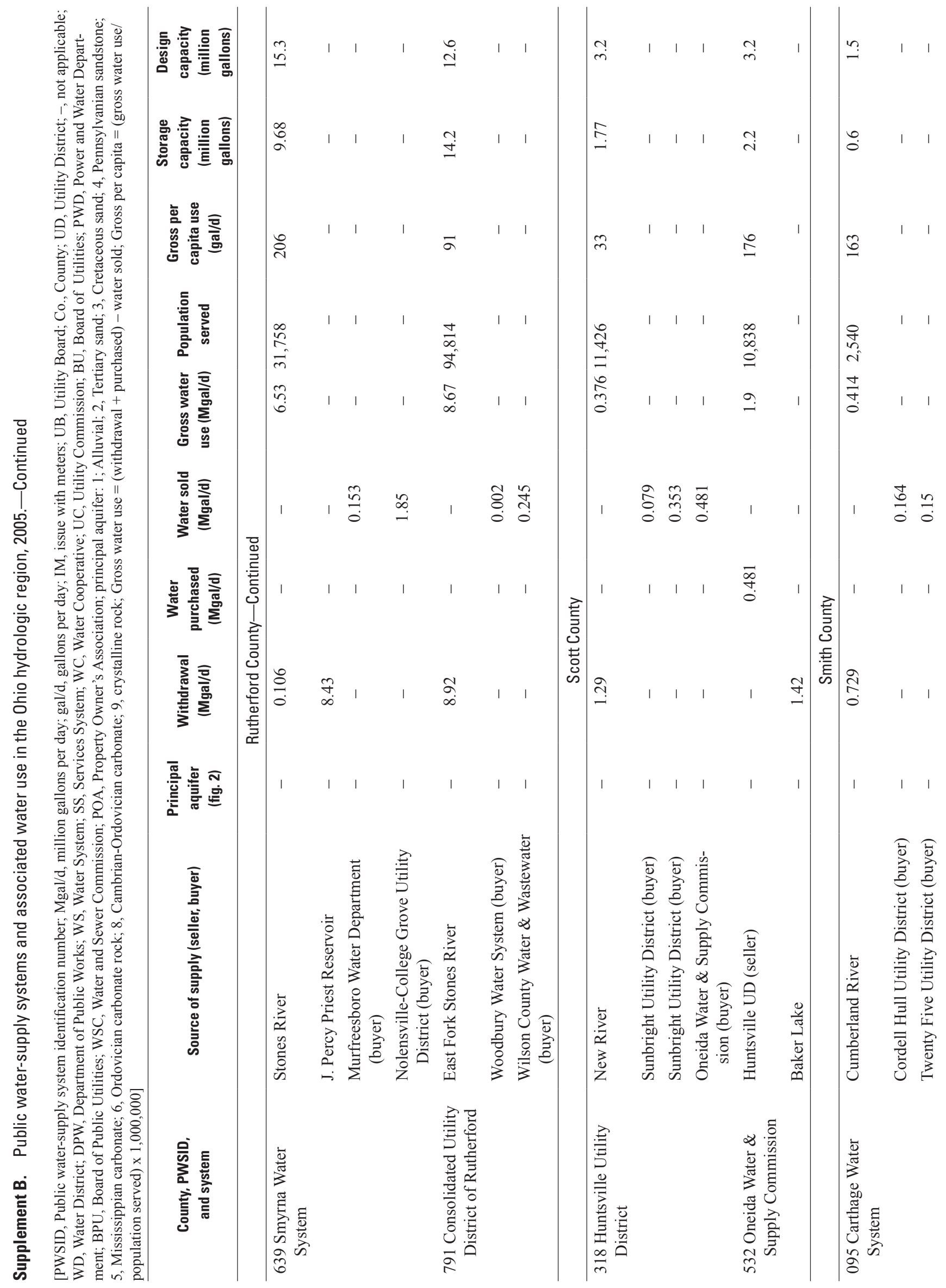




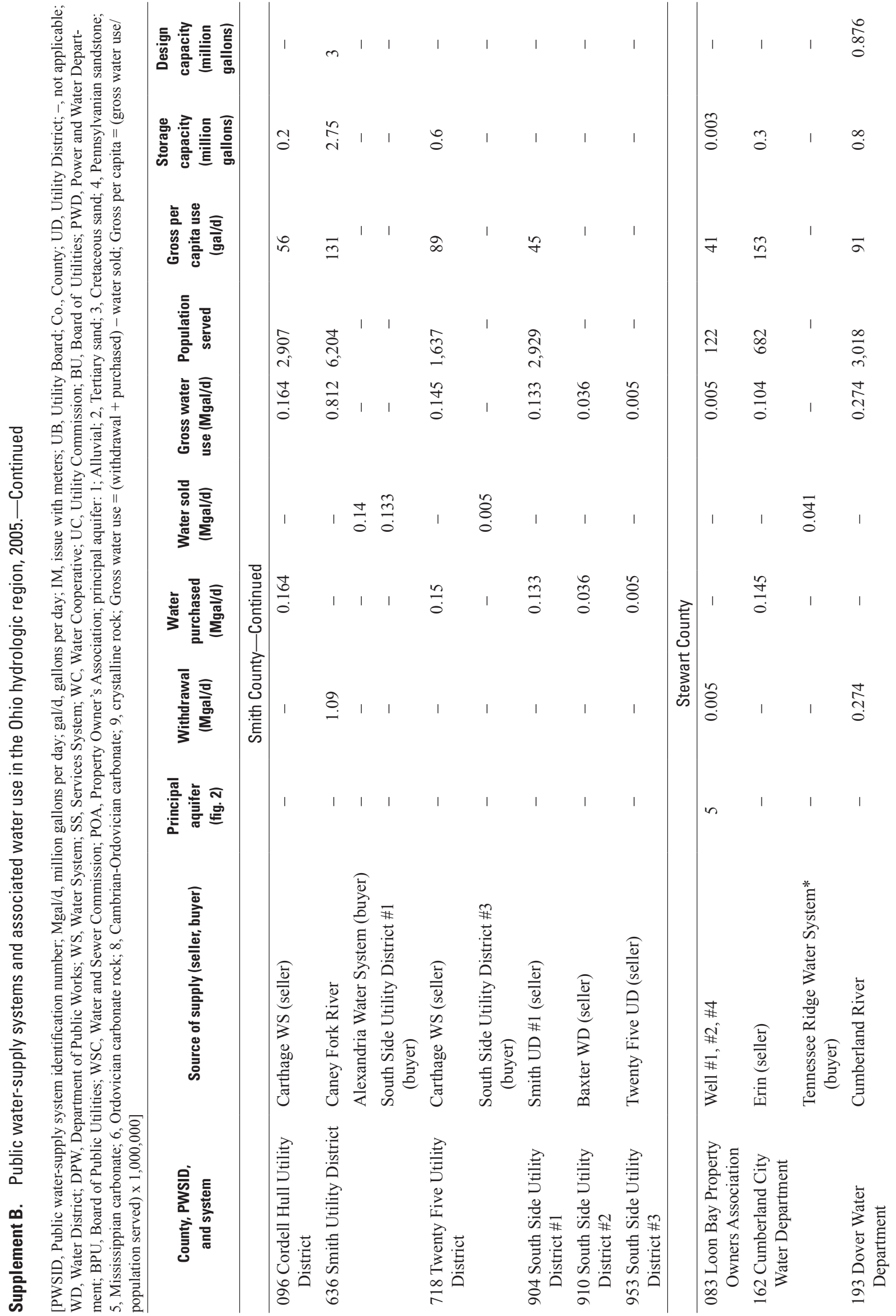




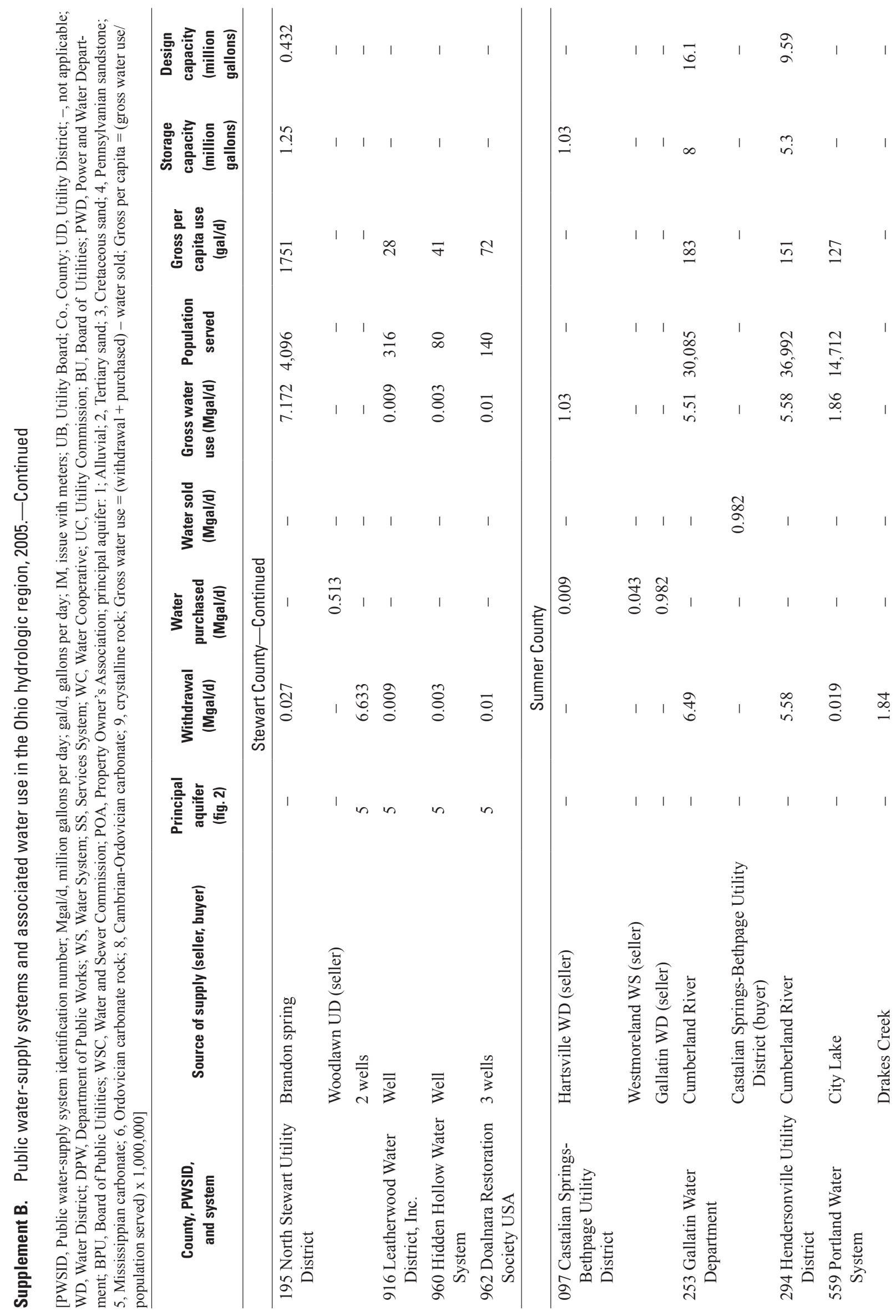




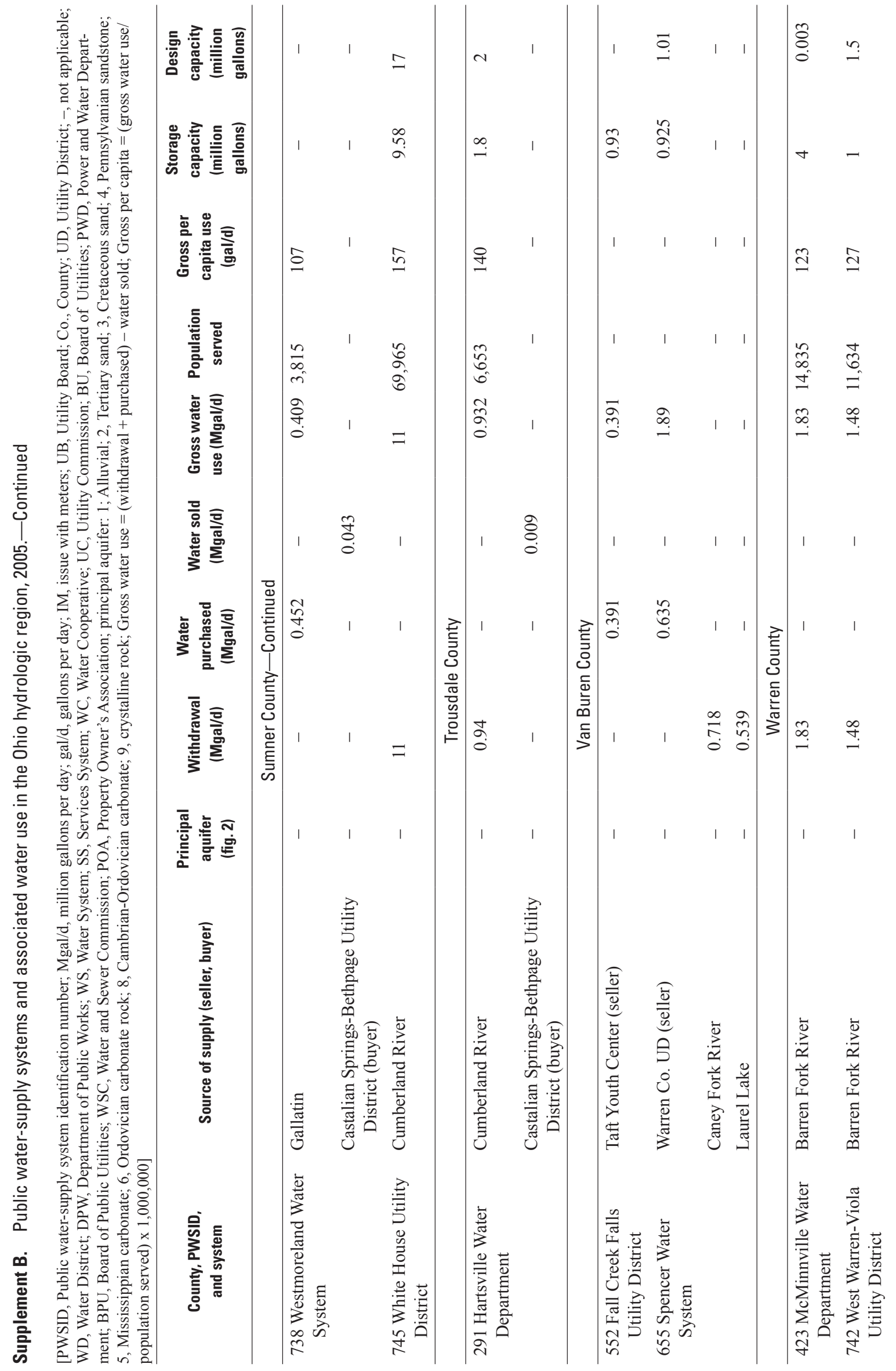




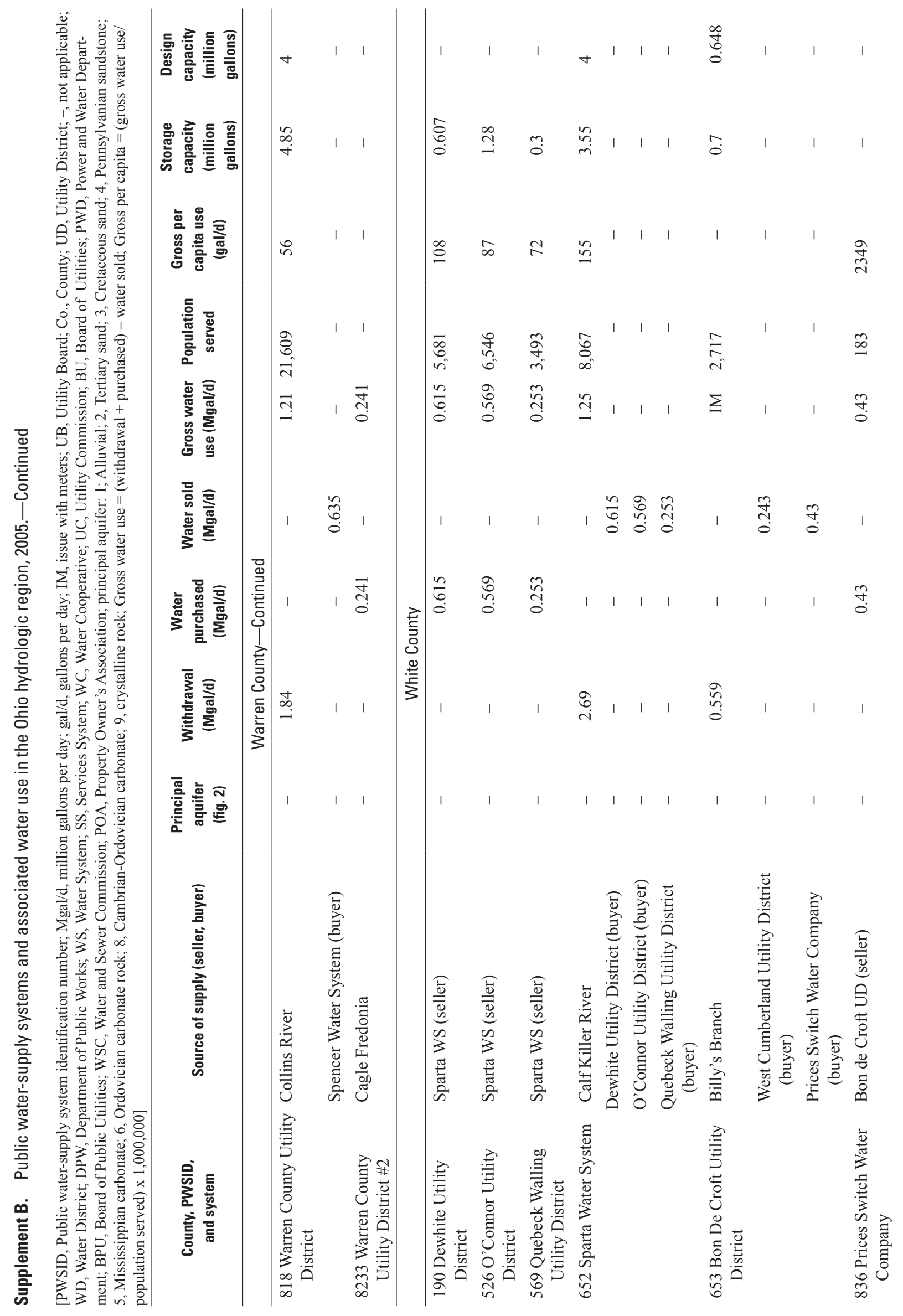




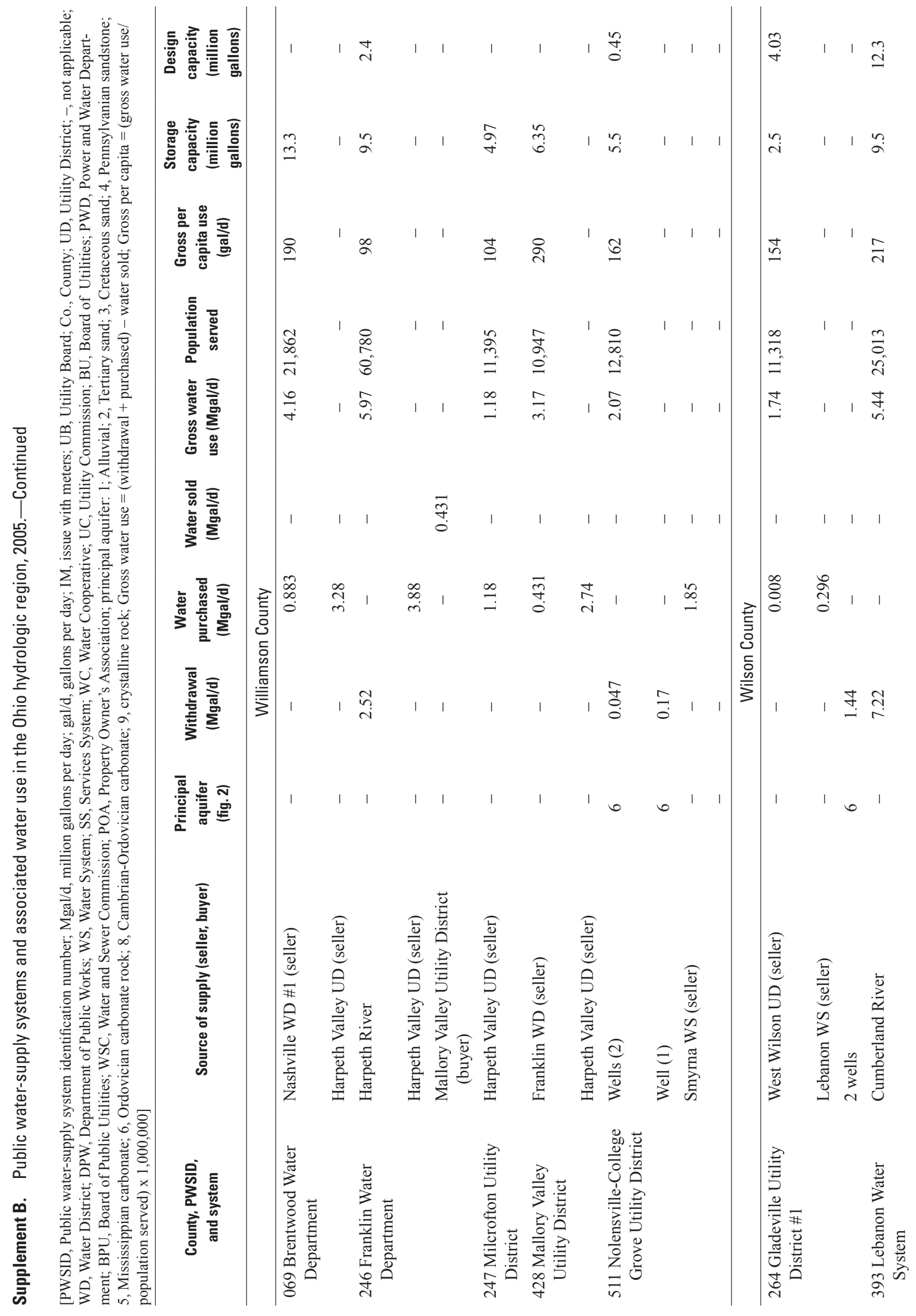




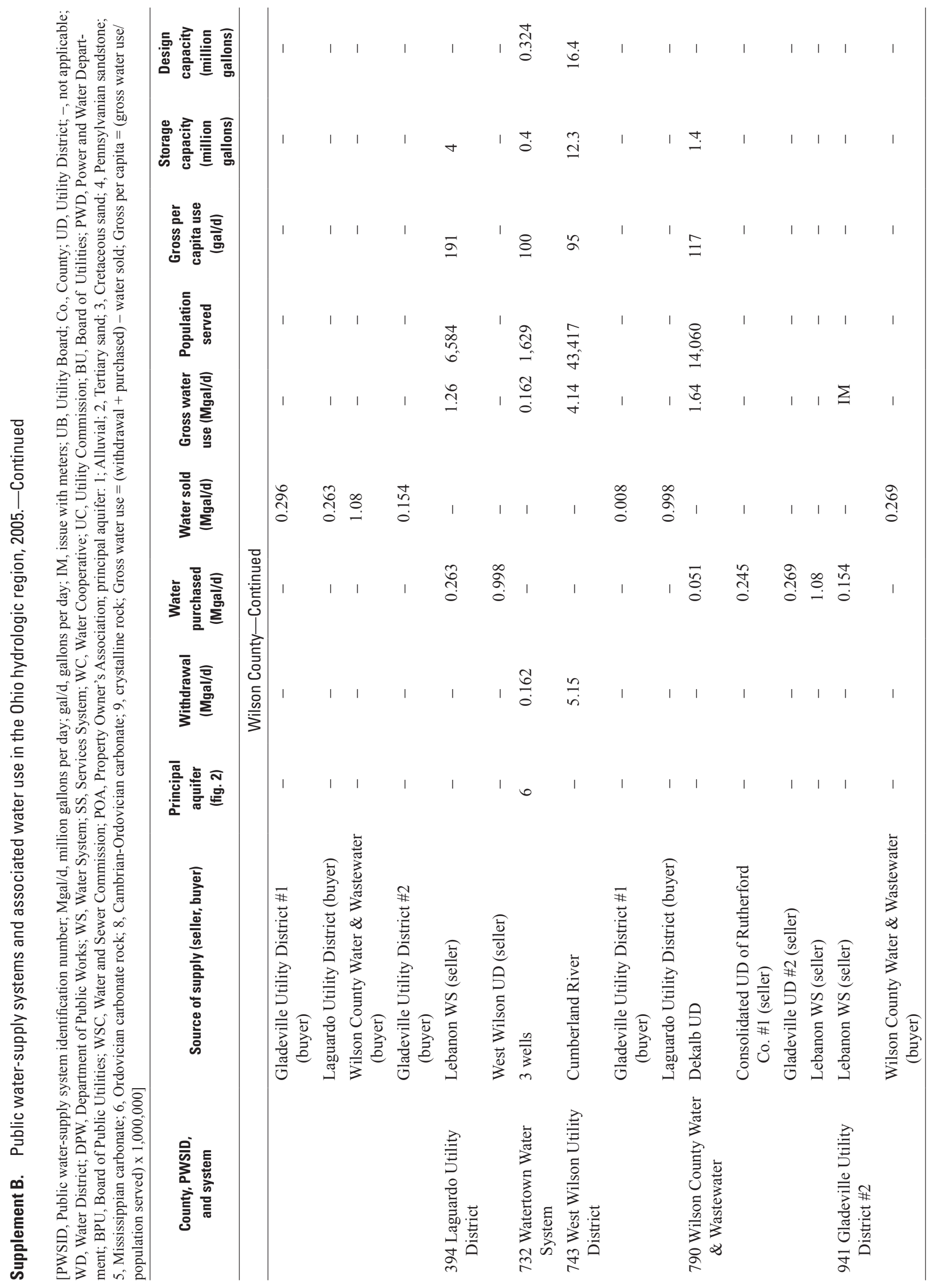


Supplement C-Public water-supply systems and associated water use in the Lower Mississippi hydrologic region 


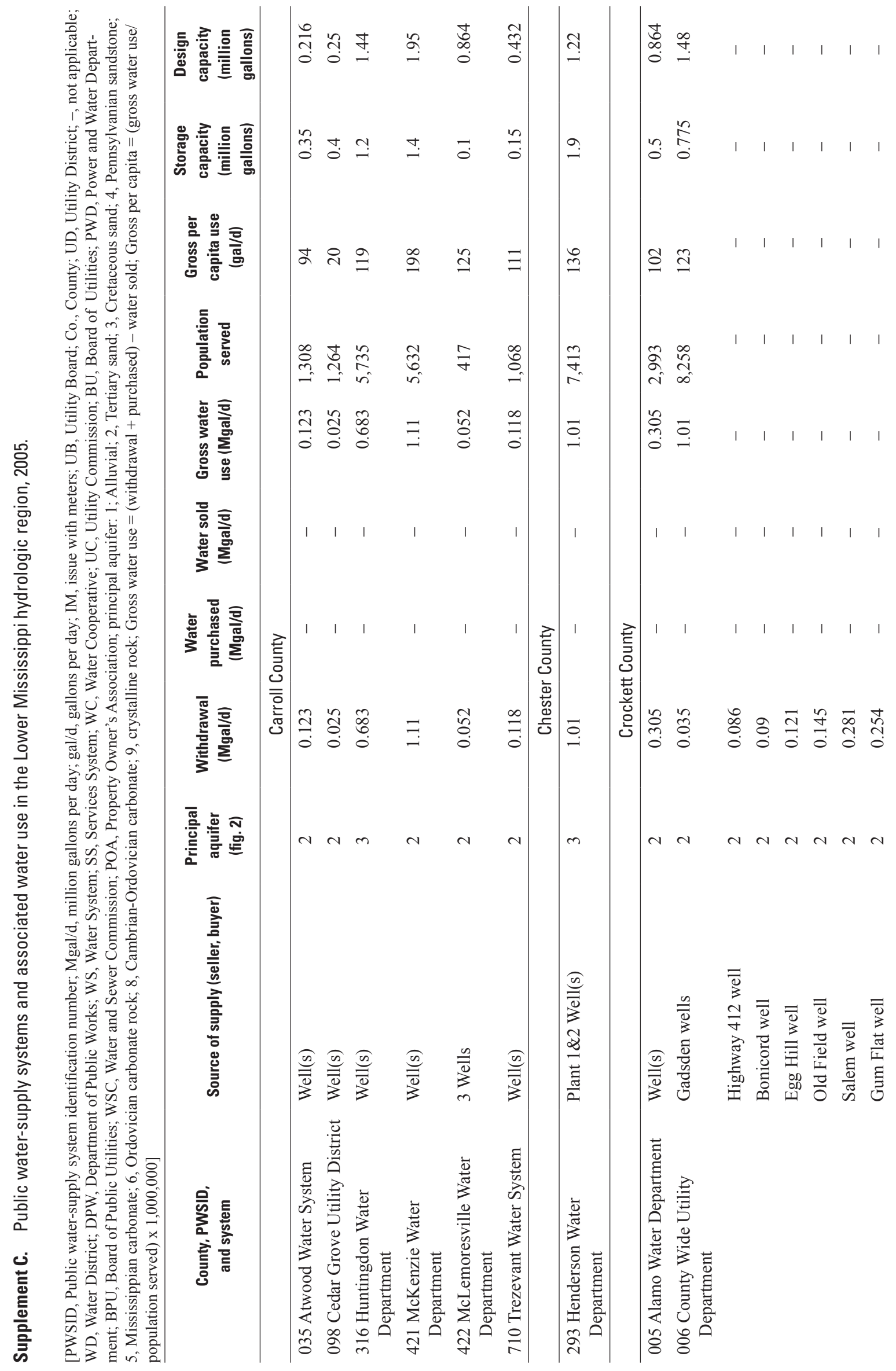




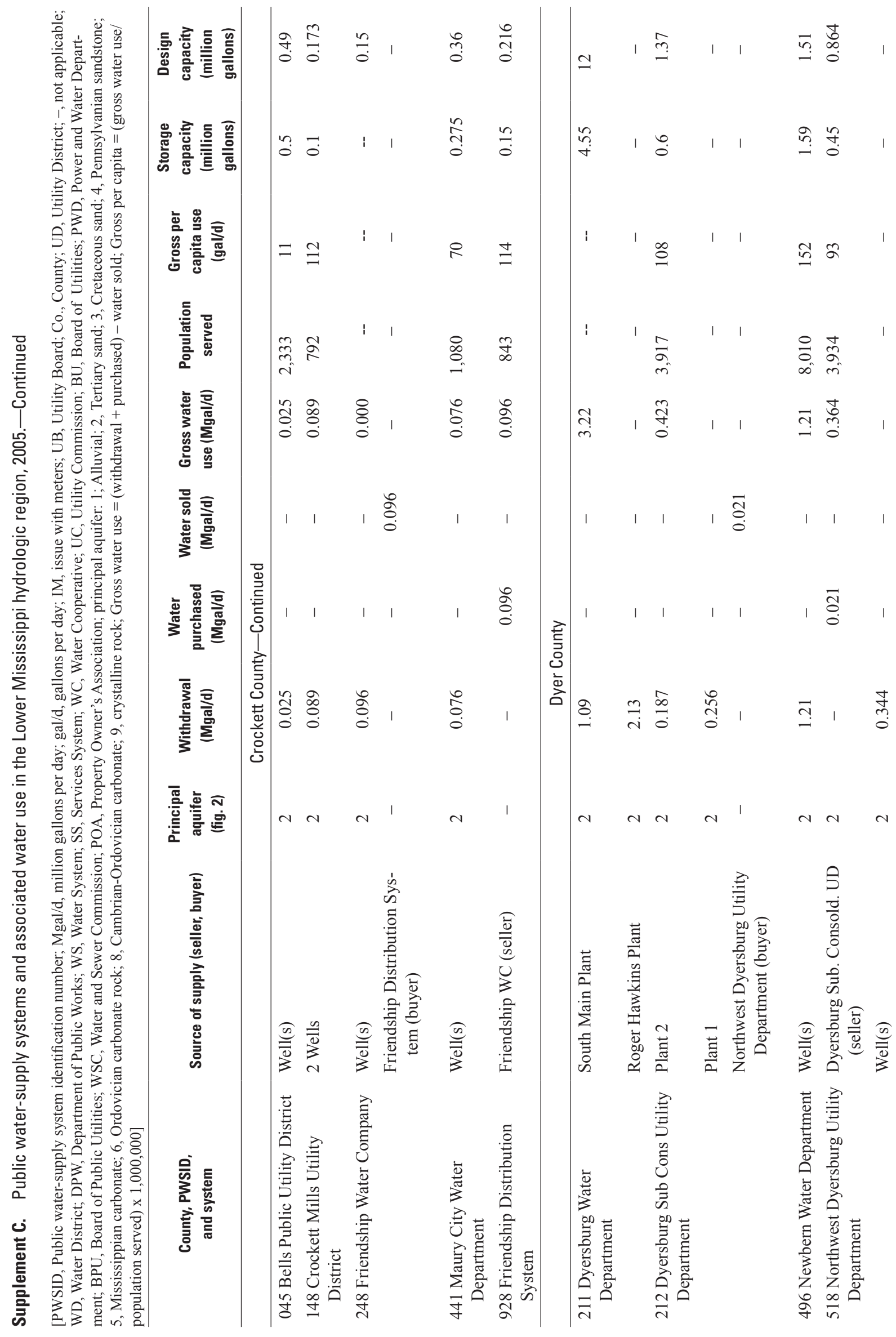




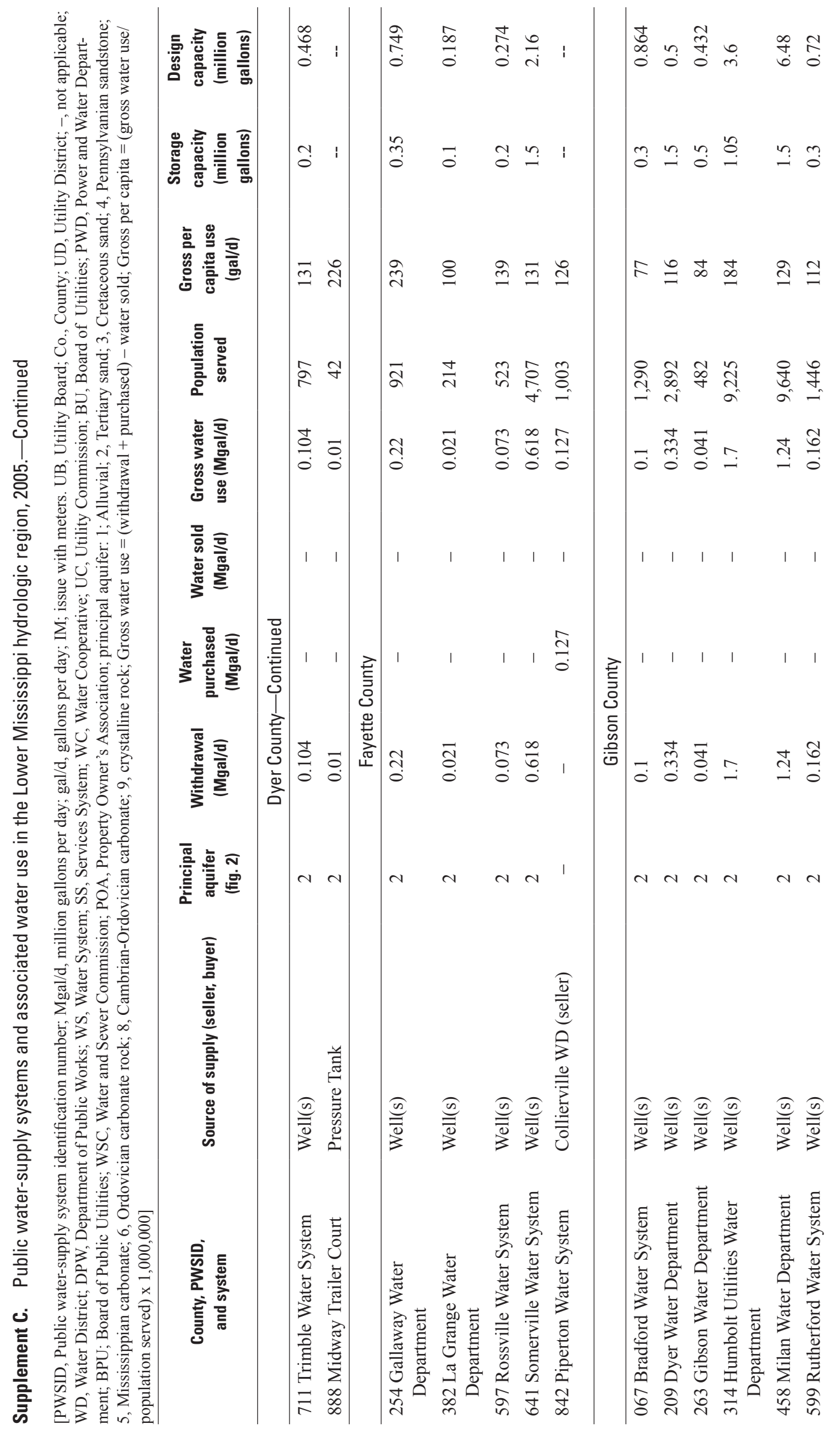




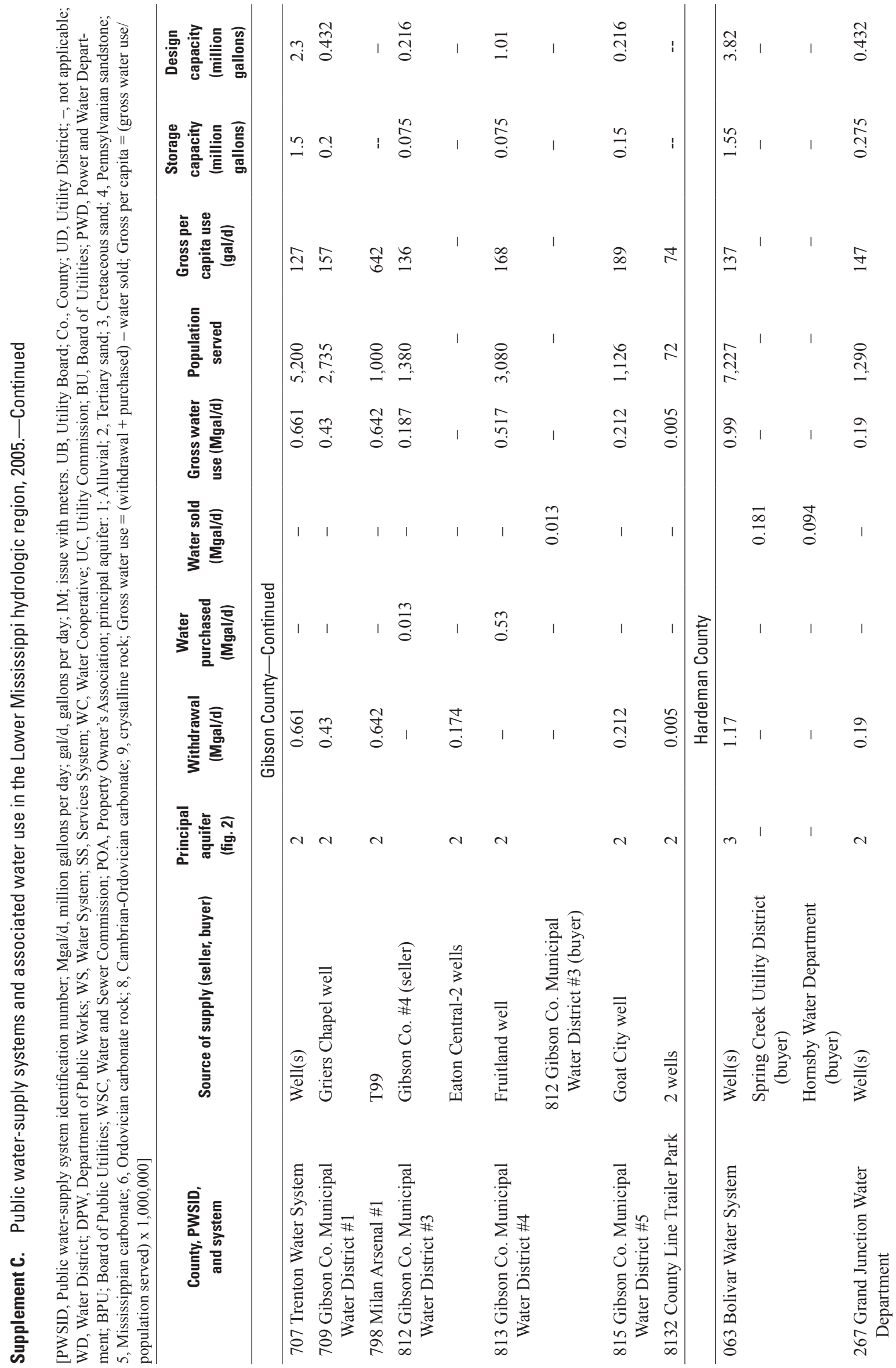




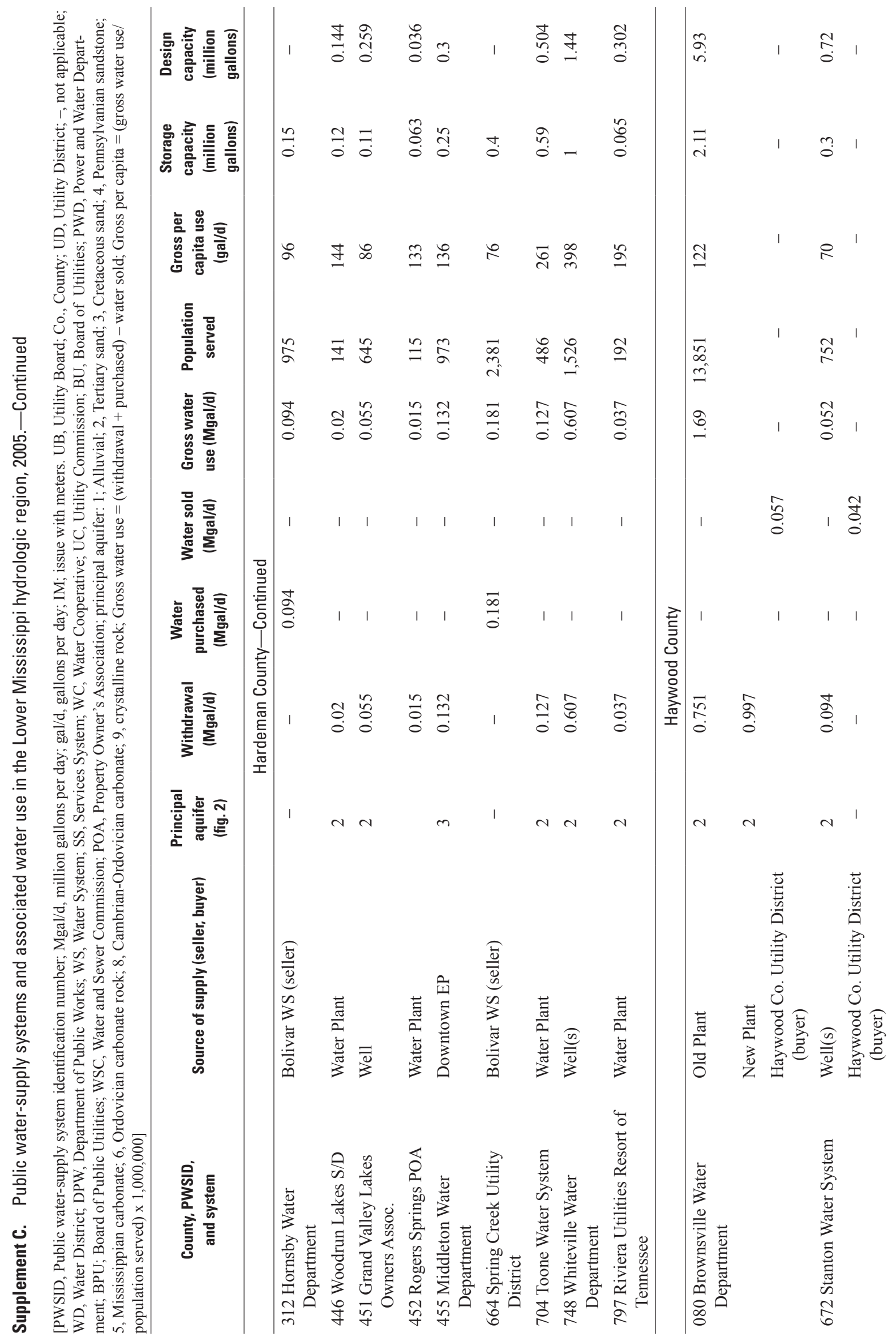




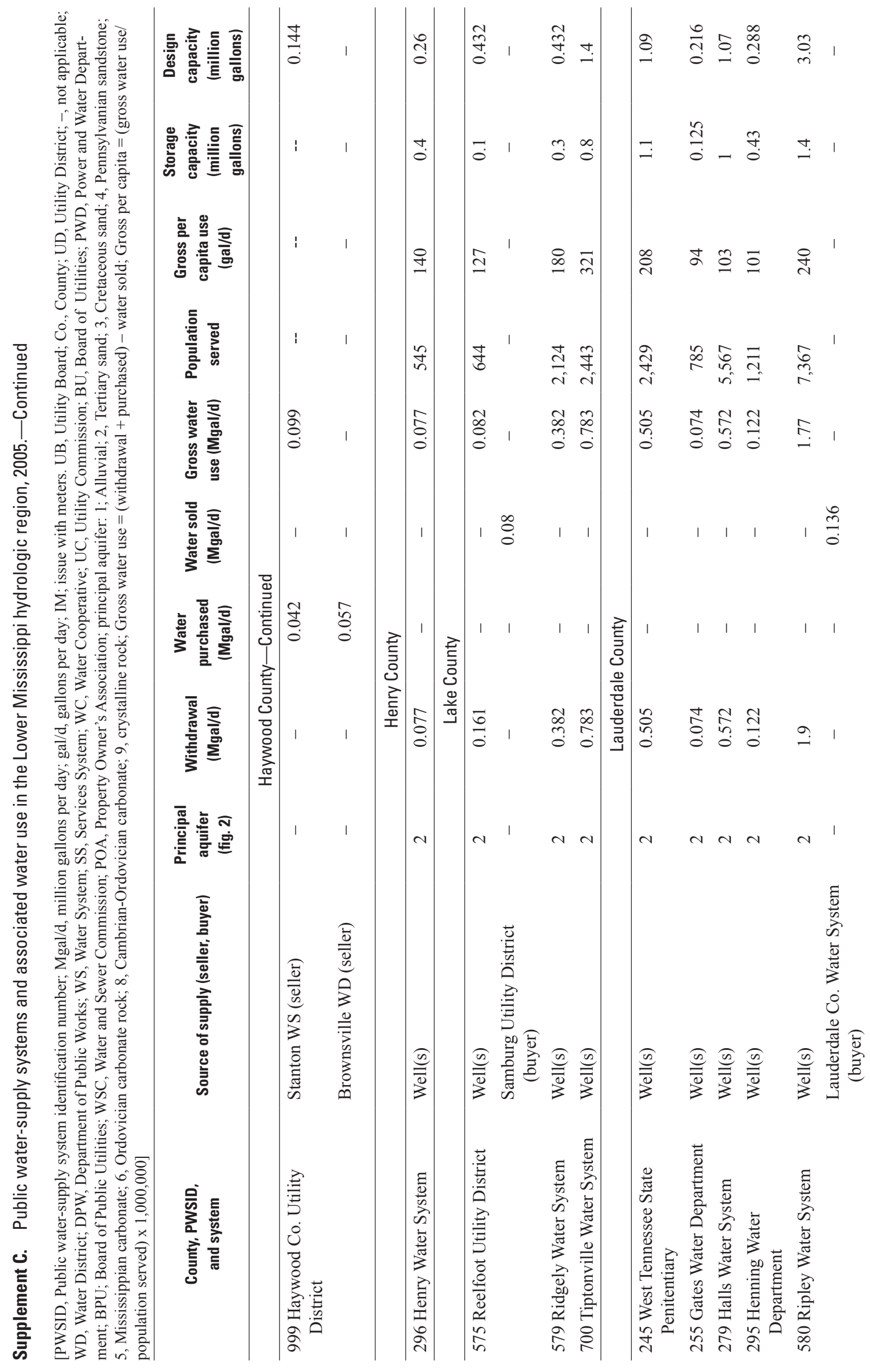




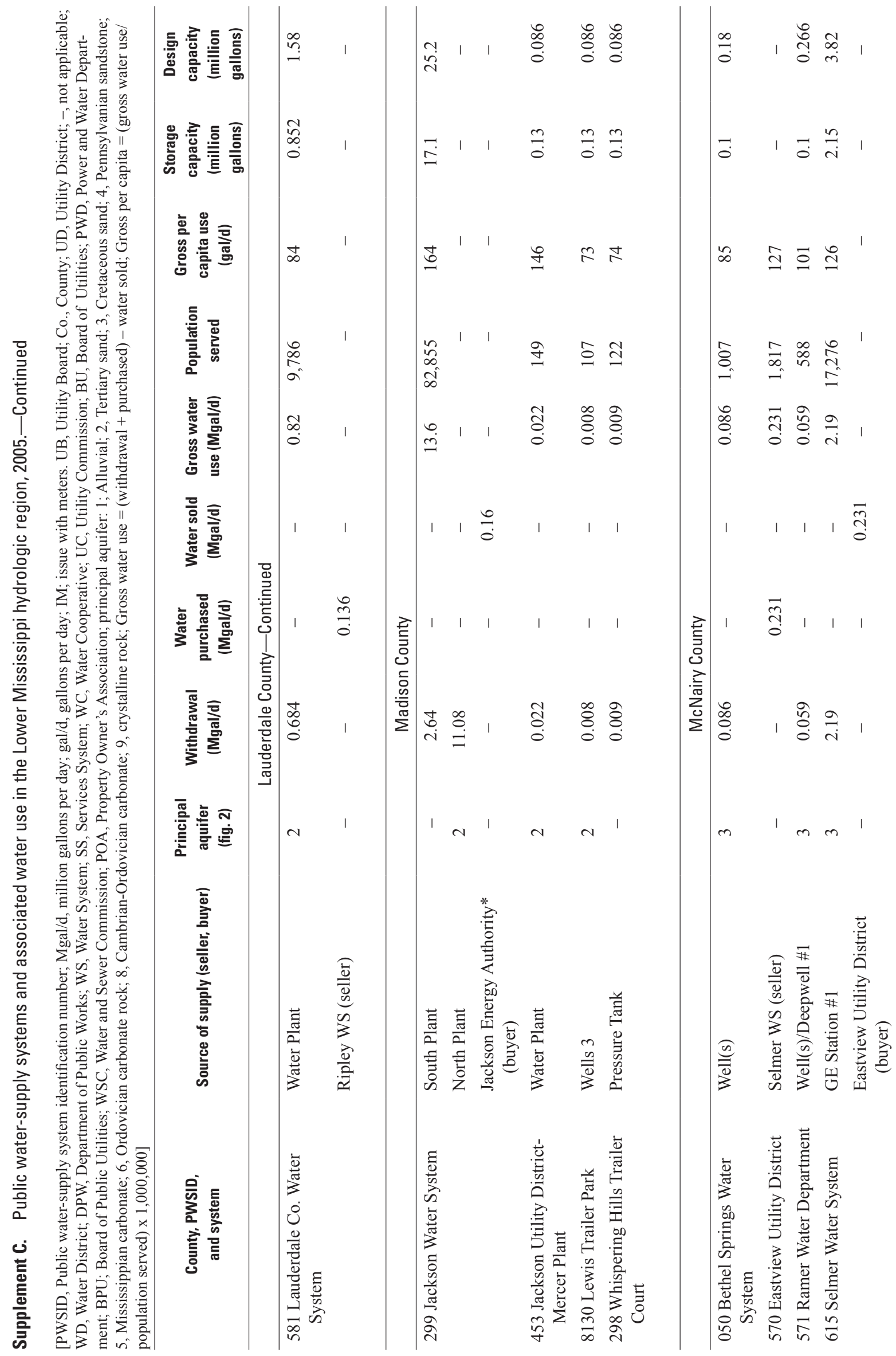




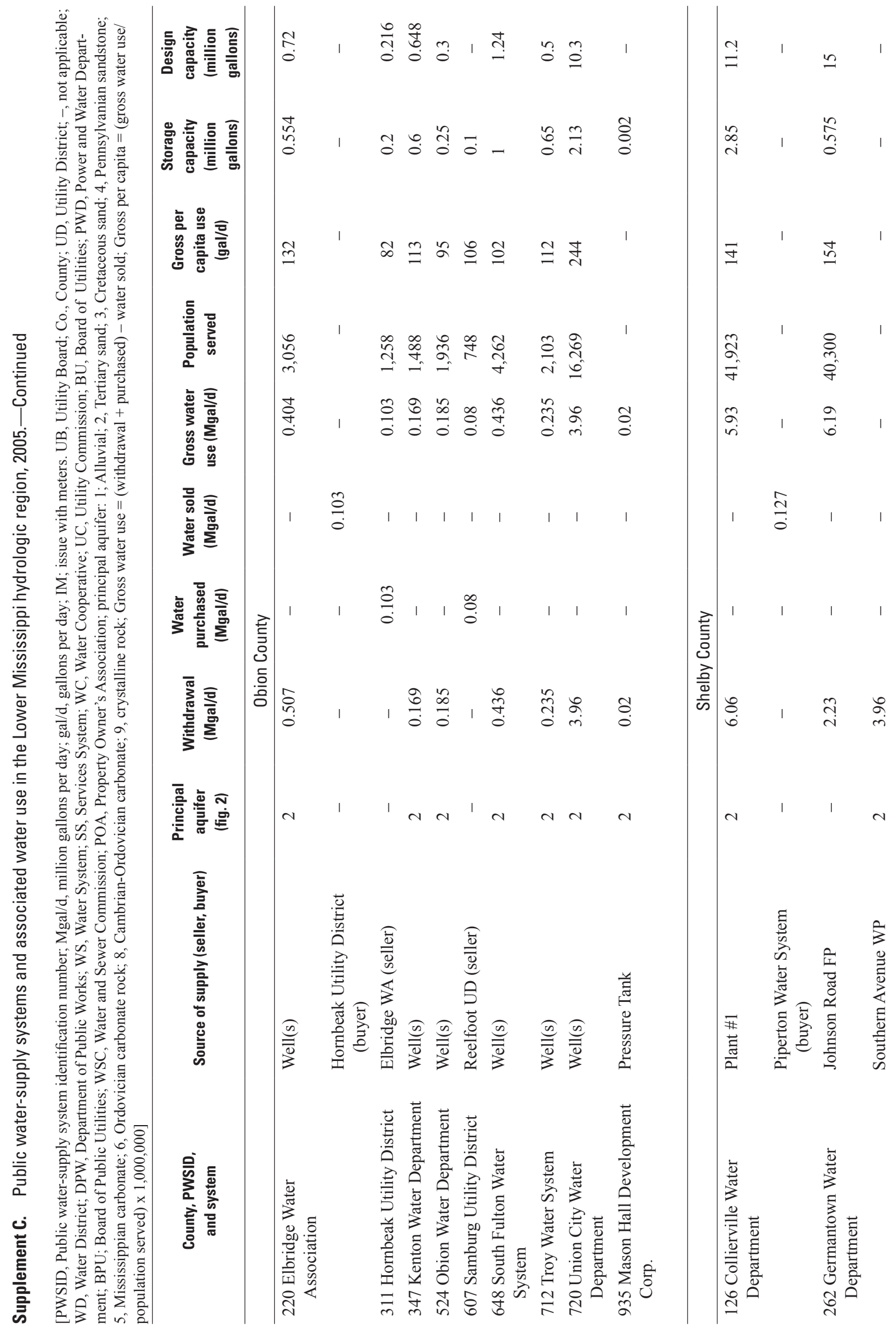




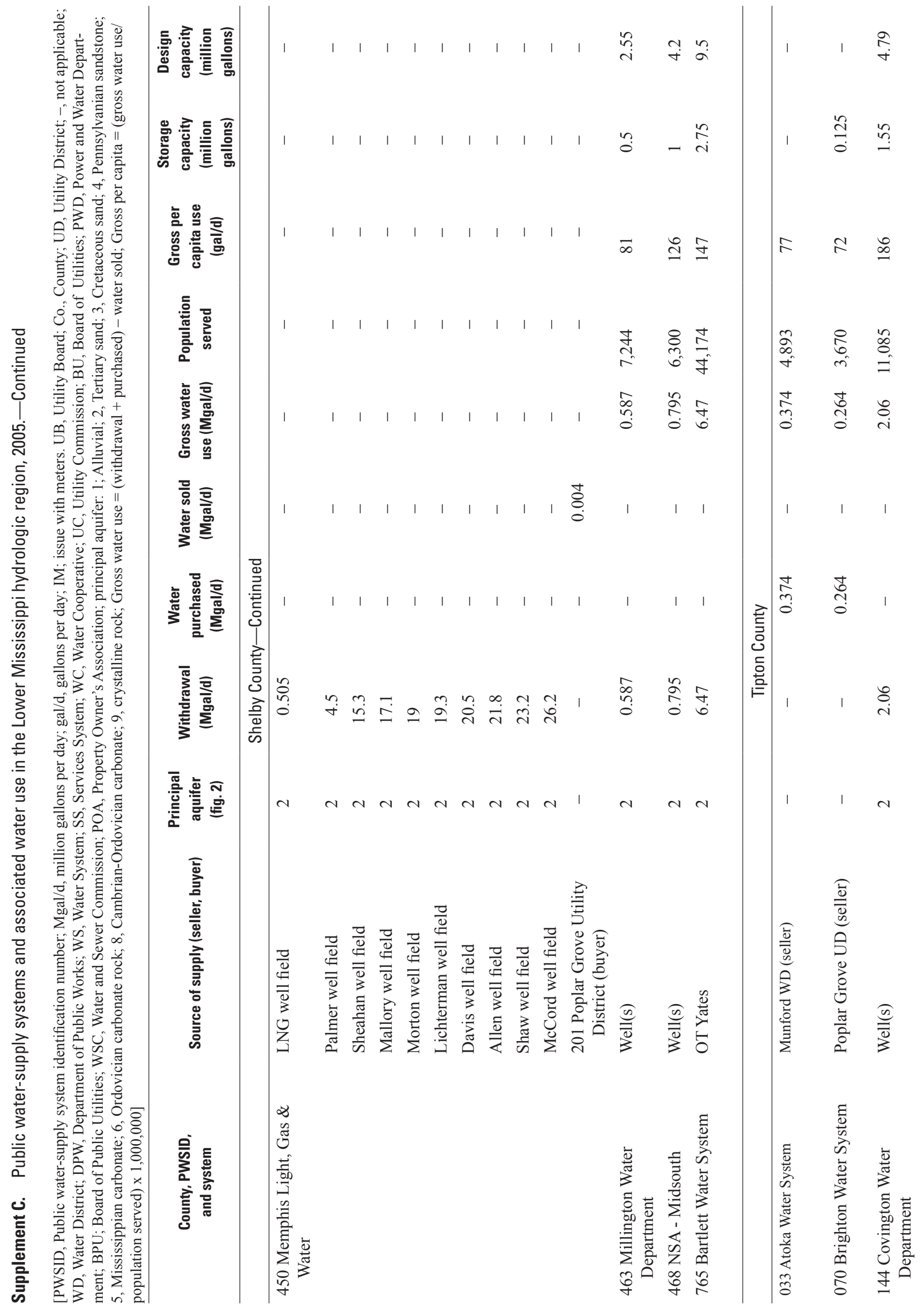



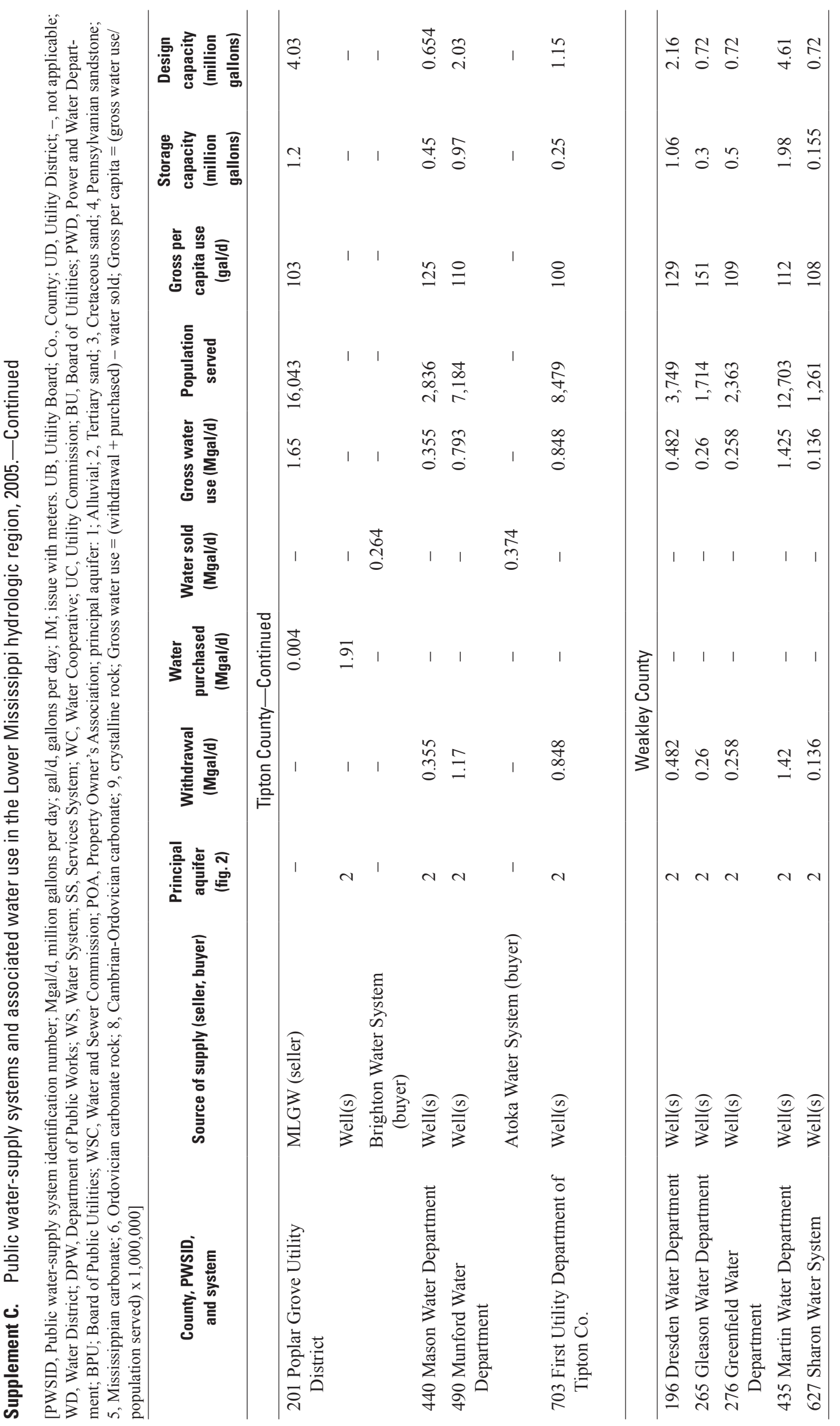

Index 
Index

Public water-supply systems in

Tennessee, 2005

\begin{tabular}{|c|c|c|}
\hline \multicolumn{3}{|c|}{$\begin{array}{c}\text { Public Water } \\
\text { System } \\
\text { Identification }\end{array}$} \\
\hline \multicolumn{3}{|c|}{$\mathrm{A}$} \\
\hline 001 & Adams-Cedar Hill Water System & $\mathrm{B}$ \\
\hline 002 & Adamsville Water System & $\mathrm{A}$ \\
\hline 005 & Alamo Water Department & $\mathrm{C}$ \\
\hline 007 & Alcoa Water System & A \\
\hline 008 & Alexandria Water System & $\mathrm{B}$ \\
\hline 009 & Algood Water System & $\mathrm{B}$ \\
\hline 010 & Allardt Water Works & $\mathrm{B}$ \\
\hline 974 & Allendale Drive Mobile Home Park & A \\
\hline 014 & Alpha-Talbott Utility District & $\mathrm{A}$ \\
\hline 768 & Anderson County Utility Board & $\mathrm{A}$ \\
\hline 539 & Antioch Water Company & A \\
\hline 948 & Aqua Utilities Co, Inc. & $\mathrm{A}$ \\
\hline 018 & Ardmore Water System & $\mathrm{A}$ \\
\hline 022 & Arthur-Shawnee Utility District & A \\
\hline 023 & Ashland City Water Dept & B \\
\hline 024 & Athens Utilities Board & A \\
\hline 033 & Atoka Water System & $\mathrm{C}$ \\
\hline 035 & Atwood Water System & $\mathrm{C}$ \\
\hline \multicolumn{3}{|c|}{ B } \\
\hline 329 & Baneberry Utility District & $\mathrm{A}$ \\
\hline 038 & Bangham Utility District & B \\
\hline 765 & Bartlett Water System & $\mathrm{C}$ \\
\hline 040 & Baxter Water Department & B \\
\hline 517 & Bedford County Utility District & A \\
\hline 9940 & Beechview Corporation & A \\
\hline 044 & Bell Buckle Water System & A \\
\hline 045 & Bells Public Utility District & $\mathrm{C}$ \\
\hline 046 & Belvidere Rural Utility District & A \\
\hline 048 & Benton Water System & A \\
\hline 050 & Bethel Springs Water System & $\mathrm{C}$ \\
\hline 122 & Big Creek Utility District & $\mathrm{B}$ \\
\hline 051 & Big Sandy Water Department & A \\
\hline 056 & Bloomingdale Utility District & $\mathrm{A}$ \\
\hline 057 & Blountville Utility District & A \\
\hline 061 & Bluff City Water Department & A \\
\hline 063 & Bolivar Water System & $\mathrm{C}$ \\
\hline 066 & Bon Aqua-Lyles Utility District & A \\
\hline 653 & Bon De Croft Utility District & $\mathrm{B}$ \\
\hline 067 & Bradford Water System & $\mathrm{C}$ \\
\hline 069 & Brentwood Water Department & $\mathrm{B}$ \\
\hline 070 & Brighton Water System & $\mathrm{C}$ \\
\hline 073 & Bristol Department Utilities & $\mathrm{A}$ \\
\hline 079 & Bristol-Bluff City Utility District & $\mathrm{A}$ \\
\hline 480 & Brownlow Utility District & $\mathrm{A}$ \\
\hline 080 & Brownsville Water Department & $\mathrm{C}$ \\
\hline 081 & Bruceton Water System & A \\
\hline 520 & Brushy Mountain Prison & $\mathrm{A}$ \\
\hline 088 & Byrdstown Water Department & $\mathrm{B}$ \\
\hline
\end{tabular}


Index

Public water-supply systems in

Tennessee, 2005

\begin{tabular}{|c|c|c|}
\hline $\begin{array}{l}\text { Public Water } \\
\text { System } \\
\text { Identification } \\
\text { Number }\end{array}$ & System name & Supplement \\
\hline & $\mathrm{C}$ & \\
\hline 927 & Cagle-Fredonia Utility District & A \\
\hline 106 & Calhoun-Charleston Utility District & A \\
\hline 090 & Camden Water Department & A \\
\hline 8219 & Camelia Trace Apartments & A \\
\hline 085 & Carderview Utility District & A \\
\hline 095 & Carthage Water System & $\mathrm{B}$ \\
\hline 322 & Caryville-Jacksboro Utility District & A \\
\hline 097 & Castalian Springs-Bethpage Utility District & $\mathrm{B}$ \\
\hline 158 & Catoosa Utility District & A \\
\hline 098 & Cedar Grove Utility District & $\mathrm{C}$ \\
\hline 8214 & Cedar Hill Apartments & A \\
\hline 099 & Celina Water System & B \\
\hline 101 & Center Grove-Winchester Springs & A \\
\hline 103 & Centerville Water System & A \\
\hline 849 & Chalet Village North & A \\
\hline 875 & Chanute-Pall Mall Utility District & B \\
\hline 104 & Chapel Hill Water System & A \\
\hline 138 & Cherokee Hills Utility District & A \\
\hline 062 & Chinquapin Grove Utility District & A \\
\hline 108 & Chuckey Utility District & A \\
\hline 113 & Claiborne County Utility District & A \\
\hline 115 & Clarksburg Utility District & A \\
\hline 116 & Clarksville Water Department & $\mathrm{B}$ \\
\hline 826 & Clear Fork Utility District & $\mathrm{B}$ \\
\hline 117 & Cleveland Utilities & A \\
\hline 119 & Clifton Water Department & A \\
\hline 120 & Clinton Utilities Board & A \\
\hline 485 & Cold Springs Utility District & A \\
\hline 126 & Collierville Water Department & $\mathrm{C}$ \\
\hline 127 & Collinwood Water Department & A \\
\hline 128 & Columbia Water System & A \\
\hline 791 & Consolidated Utility District of Rutherford & $\mathrm{B}$ \\
\hline 134 & Cookeville Boat Dock Road Utility District & B \\
\hline 133 & Cookeville Water Dept & $\mathrm{B}$ \\
\hline 844 & Copper Basin Utility District & A \\
\hline 136 & Copperhill Water Department & A \\
\hline 096 & Cordell Hull Utility District & B \\
\hline 139 & Cornersville Water Department & A \\
\hline 8003 & Country Acres Farm & A \\
\hline 933 & Country Junction Resort & A \\
\hline 8132 & County Line Trailer Park & $\mathrm{C}$ \\
\hline 006 & County Wide Utility Department & $\mathrm{C}$ \\
\hline 144 & Covington Water Department & $\mathrm{C}$ \\
\hline 146 & Cowan Board of Public Utilities & A \\
\hline 147 & Crab Orchard Utility District & A \\
\hline 971 & Creekside Mobile Home Subdivision & A \\
\hline
\end{tabular}


Index

Public water-supply systems in

Tennessee, 2005

\begin{tabular}{|c|c|c|}
\hline $\begin{array}{l}\text { Public Water } \\
\text { System } \\
\text { Identification } \\
\text { Number }\end{array}$ & System name & Supplement \\
\hline \multicolumn{3}{|c|}{ C-Continued } \\
\hline 148 & Crockett Mills Utility District & $\mathrm{C}$ \\
\hline 149 & Cross Anchor Utility District & A \\
\hline 150 & Crossville Water Department & $\mathrm{B}$ \\
\hline 162 & Cumberland City Water Department & $\mathrm{B}$ \\
\hline 161 & Cumberland Gap Water Services & A \\
\hline 166 & Cumberland Heights Utility District & $\mathrm{B}$ \\
\hline 848 & Cumberland Mountain Retreat & A \\
\hline 4788 & Cumberland Mt. Retreat & $\mathrm{B}$ \\
\hline 531 & Cumberland Utility District & A \\
\hline 929 & $\begin{array}{l}\text { Cunningham East Mont Water Treatment } \\
\text { Plant }\end{array}$ & $\mathrm{B}$ \\
\hline 167 & Cunningham Utility District & $\mathrm{B}$ \\
\hline \multicolumn{3}{|c|}{$\mathrm{D}$} \\
\hline 170 & Dandridge Water Department & $\mathrm{A}$ \\
\hline 174 & Dayton Water Department & A \\
\hline 183 & Decatur Water Department & A \\
\hline 186 & Decaturville Water System & A \\
\hline 187 & Decherd Water Department & A \\
\hline 912 & Deerfield Resort Water System & $\mathrm{B}$ \\
\hline 188 & Dekalb Utility District \#1 & $\mathrm{B}$ \\
\hline 835 & Dekalb Utility District \#4 & $\mathrm{B}$ \\
\hline 190 & Dewhite Utility District & $\mathrm{B}$ \\
\hline 193 & Dover Water Department & $\mathrm{B}$ \\
\hline 403 & Dowelltown-Liberty Utility Dist & $\mathrm{B}$ \\
\hline 196 & Dresden Water Department & $\mathrm{C}$ \\
\hline 919 & Dry Run Utility District & A \\
\hline 821 & Duck River Utility Commission & A \\
\hline 205 & Dunlap Water System & A \\
\hline 209 & Dyer Water Department & $\mathrm{C}$ \\
\hline 212 & Dyersburg Sub Cons Utility Department & $\mathrm{C}$ \\
\hline 211 & Dyersburg Water Department & $\mathrm{C}$ \\
\hline \multicolumn{3}{|c|}{$E$} \\
\hline 853 & East Fork Utility District & $\mathrm{B}$ \\
\hline 218 & East Montgomery Utility District & $\mathrm{B}$ \\
\hline 219 & Eastside Utility District & A \\
\hline 570 & Eastview Utility District & $\mathrm{C}$ \\
\hline 220 & Elbridge Water Association & $\mathrm{C}$ \\
\hline 221 & Elizabethton Water Department & A \\
\hline 224 & Englewood Water Department & A \\
\hline 230 & Erin Water Treatment Plant & $\mathrm{B}$ \\
\hline 231 & Erwin Utilities & A \\
\hline 232 & Estill Springs Water Department & A \\
\hline 233 & Etowah Utilities & $\mathrm{A}$ \\
\hline \multicolumn{3}{|c|}{$\mathrm{F}$} \\
\hline 563 & Fairview Utility District & A \\
\hline 552 & Fall Creek Falls Utility District & $\mathrm{B}$ \\
\hline 239 & Fall River Road Utility District & A \\
\hline 242 & Fayetteville Water System & A \\
\hline
\end{tabular}


Index

Public water-supply systems in

Tennessee, 2005

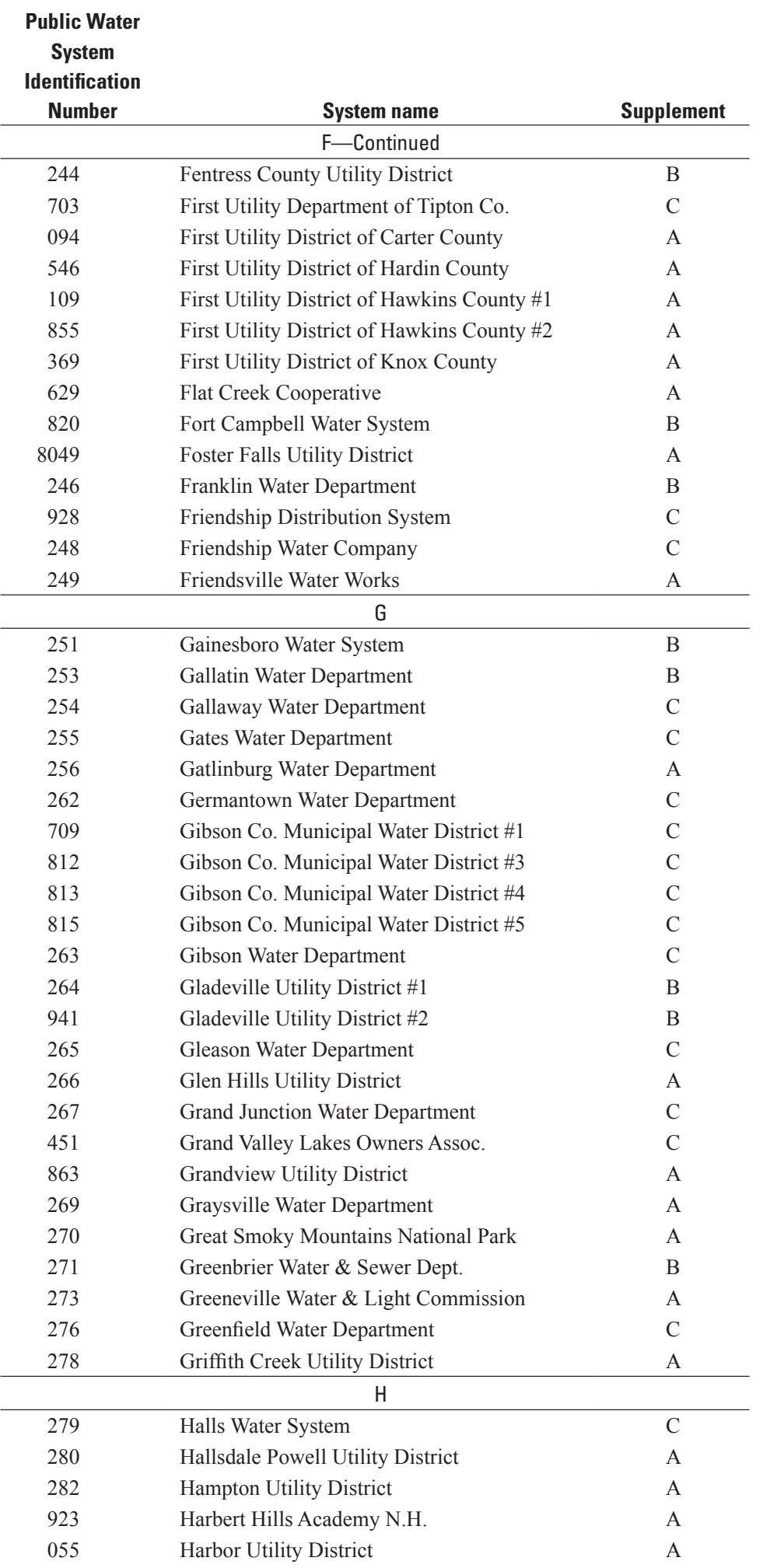




\author{
Index \\ Public water-supply systems in \\ Tennessee, 2005
}

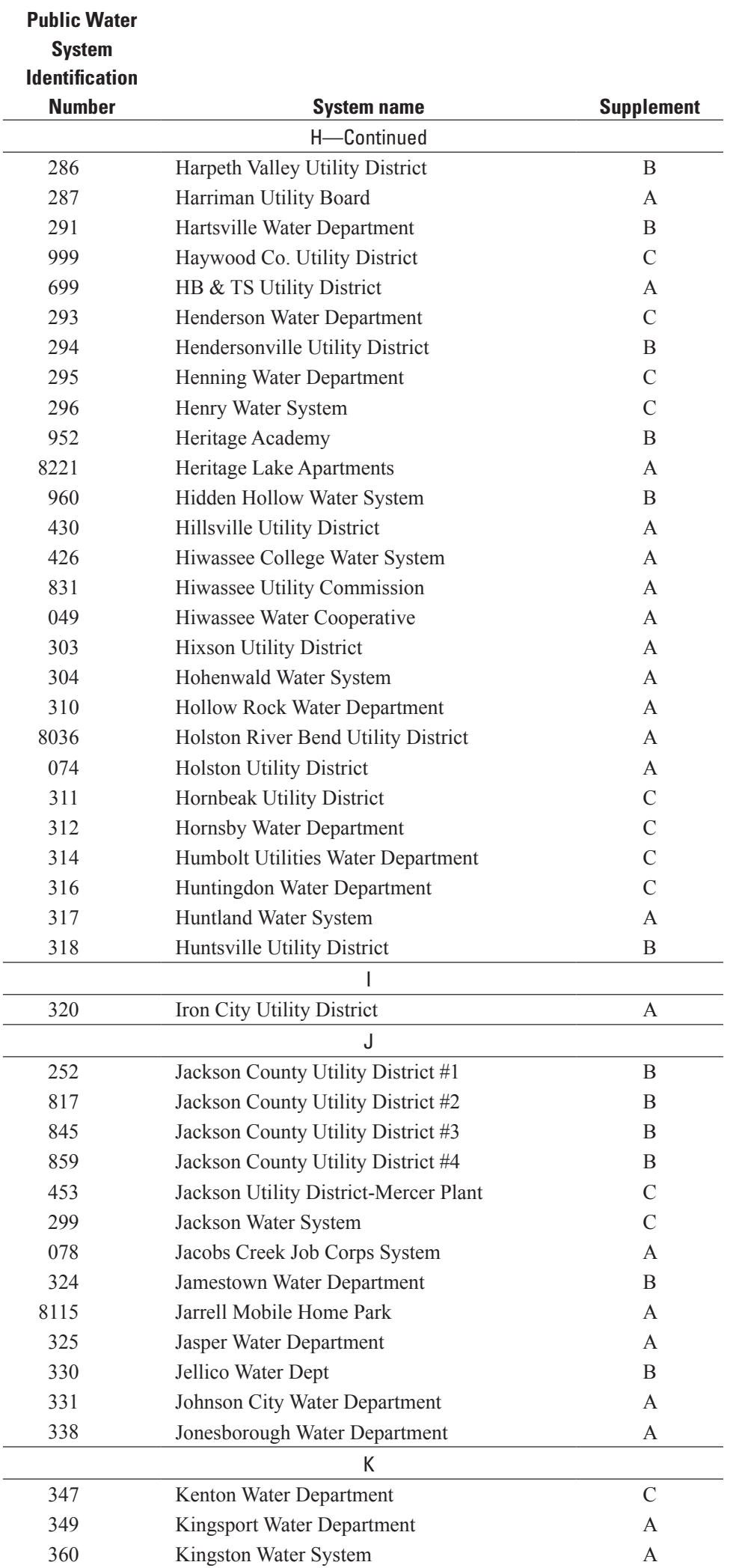


Index

Public water-supply systems in

Tennessee, 2005

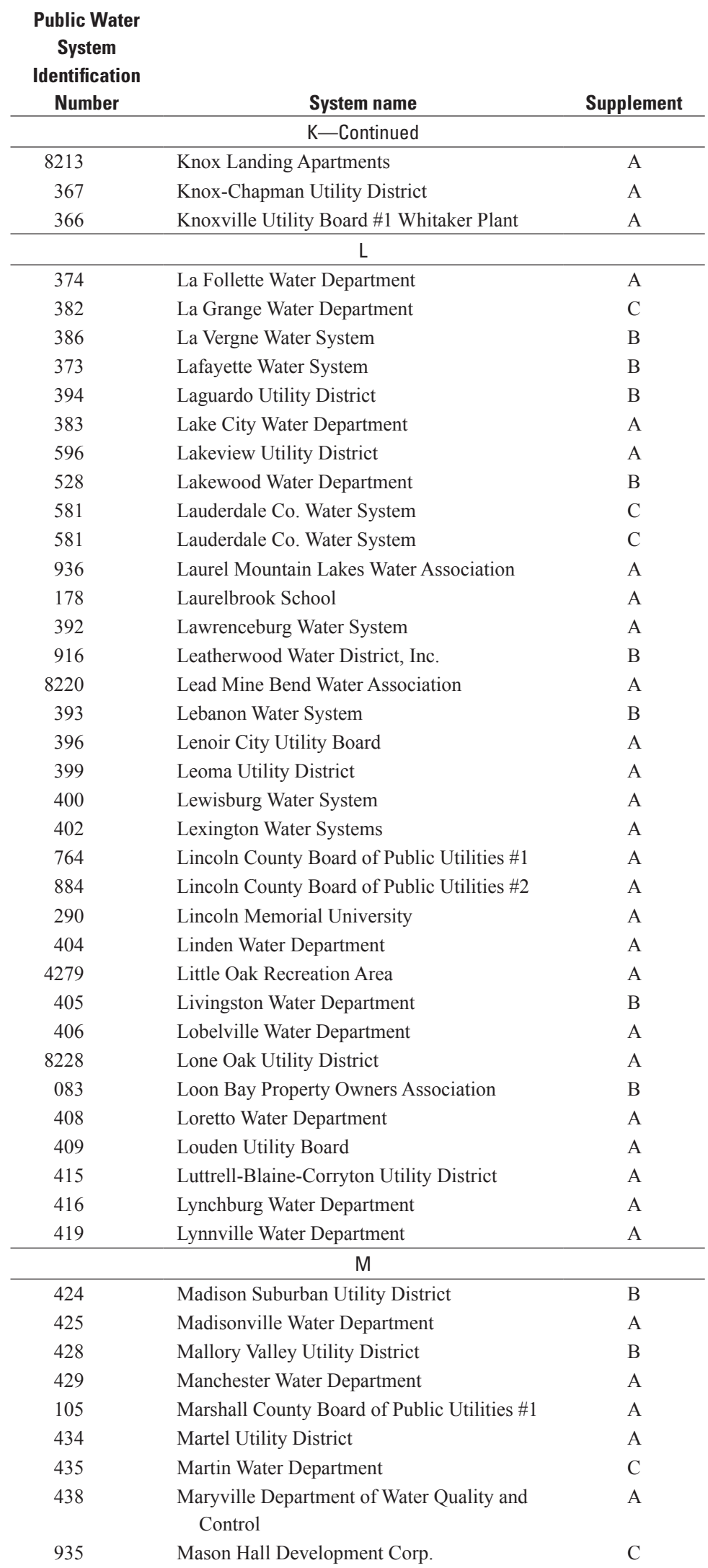


Index

Public water-supply systems in

Tennessee, 2005

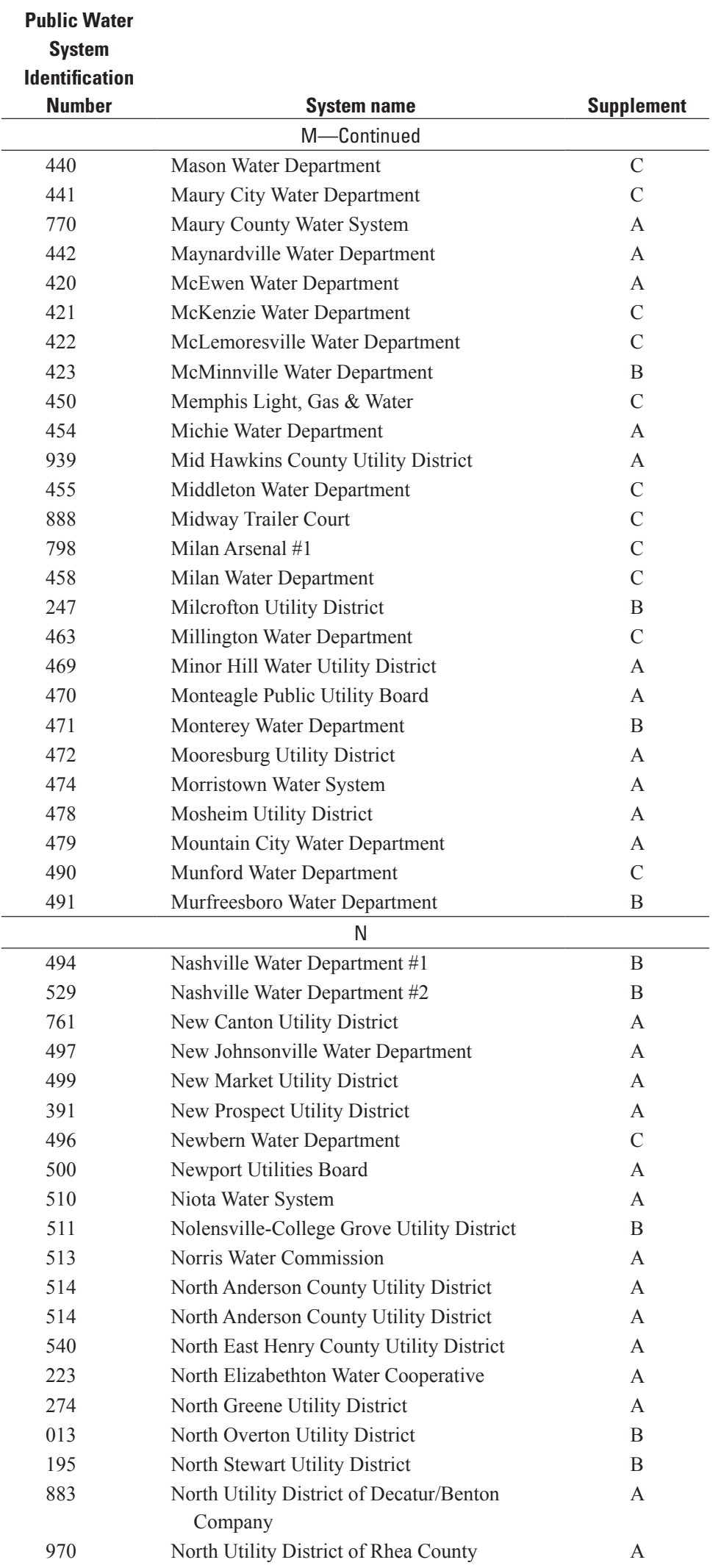




\section{Index \\ Public water-supply systems in \\ Tennessee, 2005}

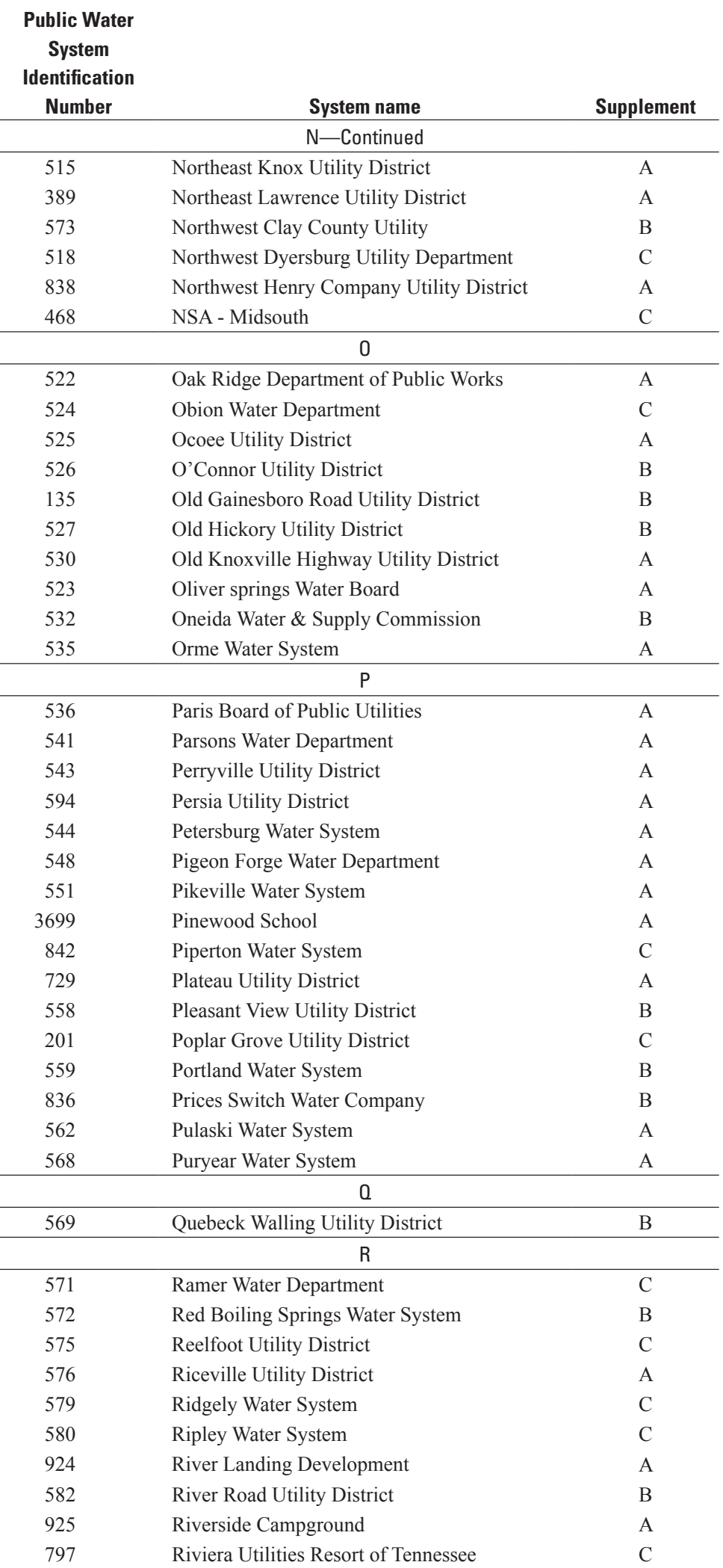




\section{Index \\ Public water-supply systems in \\ Tennessee, 2005}

\begin{tabular}{|c|c|c|}
\hline \multicolumn{3}{|c|}{$\begin{array}{l}\text { Public Water } \\
\text { System }\end{array}$} \\
\hline Number & System name & Supplement \\
\hline \multicolumn{3}{|c|}{ R-Continued } \\
\hline 584 & Roan Mountain Utility District & $\mathrm{A}$ \\
\hline 457 & Roane Central Utility District & A \\
\hline 926 & Robindale Water Association & A \\
\hline 590 & Rockwood Water System & $\mathrm{A}$ \\
\hline 452 & Rogers Springs POA & $\mathrm{C}$ \\
\hline 593 & Rogersville Water System & A \\
\hline 597 & Rossville Water System & $\mathrm{C}$ \\
\hline 598 & Russellville Whitesburg Utility District & A \\
\hline 599 & Rutherford Water System & $\mathrm{C}$ \\
\hline \multicolumn{3}{|c|}{$S$} \\
\hline 605 & Sale Creek Utility District & $\mathrm{A}$ \\
\hline 606 & Saltillo Utility District & A \\
\hline 607 & Samburg Utility District & $\mathrm{C}$ \\
\hline 5080 & Sandy Beach Water System & A \\
\hline 609 & Sardis Water System & A \\
\hline 611 & Savannah Utility Department & A \\
\hline 613 & Savannah Valley Utility District & A \\
\hline 614 & Scotts Hill Water System & A \\
\hline 645 & Second South Cheatham Utility District & B \\
\hline 615 & Selmer Water System & $\mathrm{C}$ \\
\hline 623 & Sewanee Utility District & A \\
\hline 626 & Shady Grove Utility District & A \\
\hline 627 & Sharon Water System & $\mathrm{C}$ \\
\hline 628 & Shelbyville Water System & $\mathrm{A}$ \\
\hline 633 & Siam Utility District & A \\
\hline 634 & Signal Mountain Water System & A \\
\hline 636 & Smith Utility District & $\mathrm{B}$ \\
\hline 637 & Smithville Water System & $\mathrm{B}$ \\
\hline 639 & Smyrna Water System & $\mathrm{B}$ \\
\hline 640 & Sneedville Utility District & A \\
\hline 641 & Somerville Water System & $\mathrm{C}$ \\
\hline 643 & South Blount Utility District & A \\
\hline 644 & South Bristol-Weaver Pike Utility District & A \\
\hline 159 & South Cumberland Utility District & A \\
\hline 646 & South Elizabethton Utility District & A \\
\hline 648 & South Fulton Water System & $\mathrm{C}$ \\
\hline 649 & South Giles Utility District & A \\
\hline 537 & South Paris Water Cooperative & A \\
\hline 651 & South Pittsburg Water System & A \\
\hline 904 & South Side Utility District \#1 & B \\
\hline 910 & South Side Utility District \#2 & $\mathrm{B}$ \\
\hline 953 & South Side Utility District \#3 & B \\
\hline 652 & Sparta Water System & $\mathrm{B}$ \\
\hline 655 & Spencer Water System & $\mathrm{B}$ \\
\hline 656 & Spring City Water System & A \\
\hline 664 & Spring Creek Utility District & $\mathrm{C}$ \\
\hline 666 & Springfield Water System & B \\
\hline 604 & St. Joseph Water System & A \\
\hline 880 & Stacey Ann's Mobile Home Park & B \\
\hline 672 & Stanton Water System & $\mathrm{C}$ \\
\hline
\end{tabular}




\section{Public water-supply systems in \\ Tennessee, 2005}

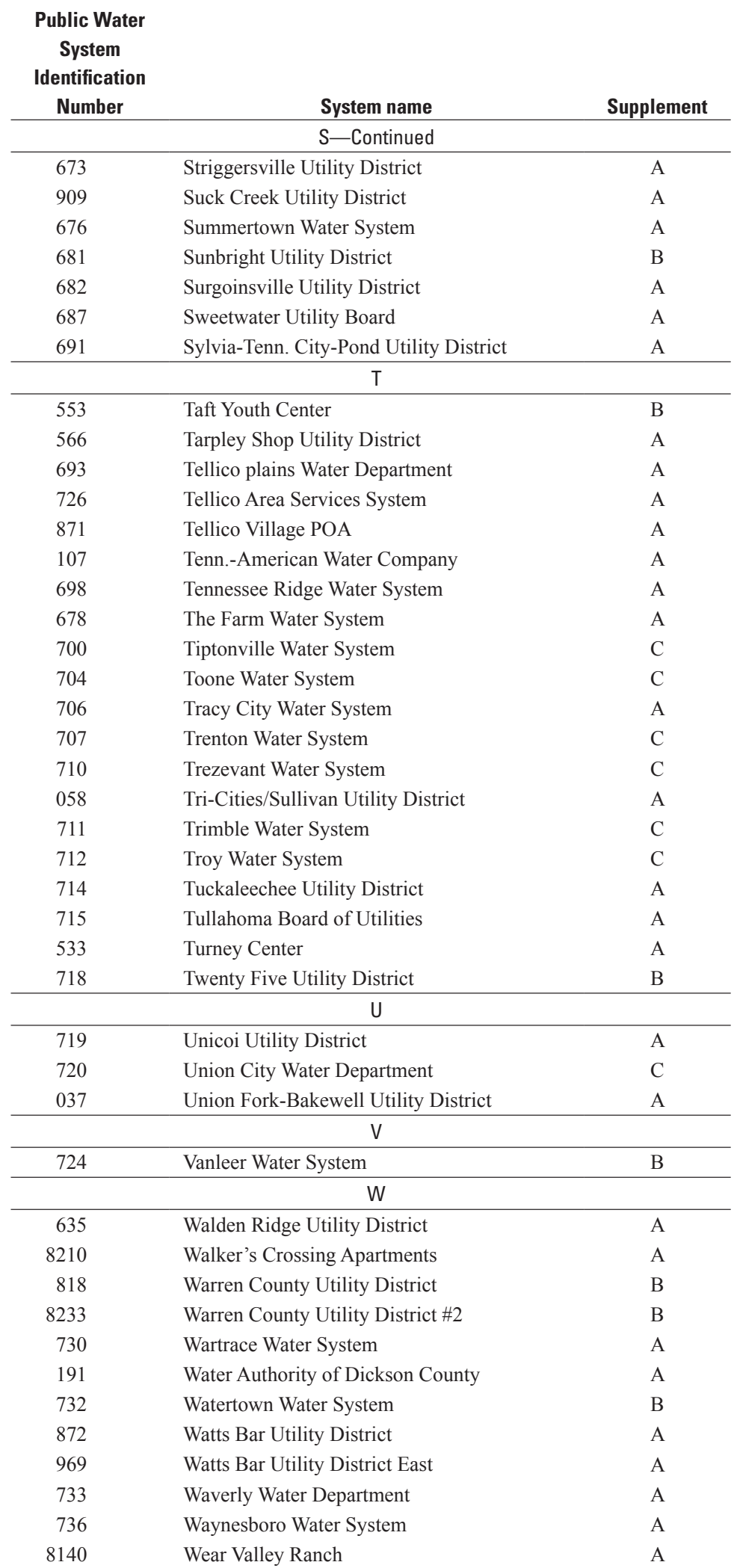




\section{Index \\ Public water-supply systems in \\ Tennessee, 2005}

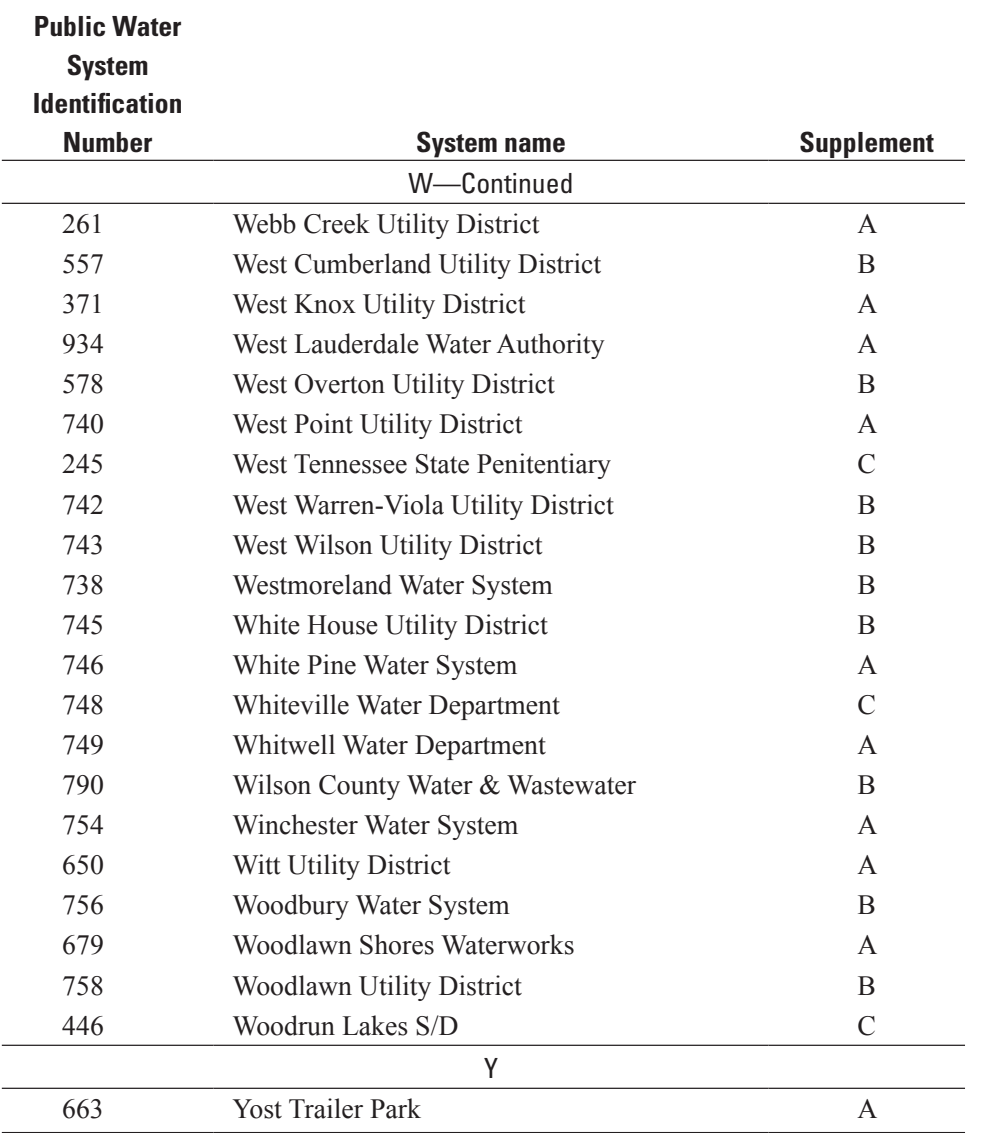

Prepared by:

USGS Publishing Network

Raleigh Publishing Service Center

3916 Sunset Ridge Road

Raleigh, NC 27607

For additional information regarding this publication, contact: USGS Tennessee Water Science Center

640 Grassmere Park, Suite 100

Nashville, TN 37211

(615) 837-4700

Or visit the USGS Tennessee Water Science Center Web site at: http://tn.water.usgs.gov 



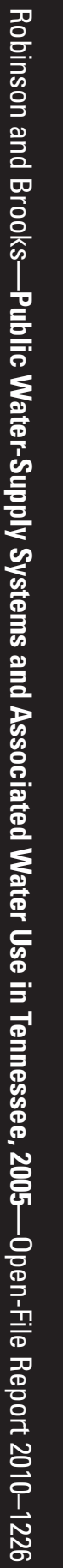

